\title{
CAMPONESES E AGROINDÚESTRIA transformação social e representação política na avicultura brasileira
}

\author{
Bernardo Sorj \\ Malori J. Pompermayer \\ Odacir Luis Coradini
}




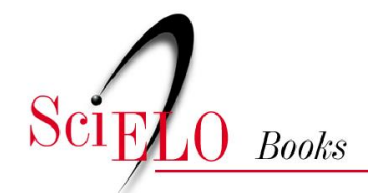

\title{
Camponeses e agroindúestria
}

transformação social e representação política na avicultura brasileira

\author{
Bernardo Sorj \\ Malori J. Pompermayer \\ Odacir Luis Coradini
}

SORJ, B., POMPERMAYER, MJ., and CORADINI, OL. Camponeses e agroindúestria:

transformação social e representação política na avicultura brasileira [online]. Rio de Janeiro: Centro Edelstein de Pesquisas Sociais, 2008. 102 p. ISBN: 978-85-99662-52-6. Available from SciELO Books $<$ http://books.scielo.org $>$.

\section{(1) $(0)$}

All the contents of this chapter, except where otherwise noted, is licensed under a Creative Commons Attribution-Non Commercial-ShareAlike 3.0 Unported.

Todo o conteúdo deste capítulo, exceto quando houver ressalva, é publicado sob a licença Creative Commons Atribuição Uso Não Comercial - Partilha nos Mesmos Termos 3.0 Não adaptada.

Todo el contenido de este capítulo, excepto donde se indique lo contrario, está bajo licencia de la licencia Creative Commons Reconocimento-NoComercial-CompartirIgual 3.0 Unported. 
Esta publicação é parte da Biblioteca Virtual de Ciências Humanas do Centro Edelstein de Pesquisas Sociais www.bvce.org

Copyright (c) 2008, Bernardo Sorj, Malori Jose Pompermayer, Odacir Luis Coradini Copyright (C) 2008 desta edição on-line: Centro Edelstein de Pesquisas Sociais Ano da última edição: 2008

Nenhuma parte desta publicação pode ser reproduzida ou transmitida por qualquer meio de comunicação para uso comercial sem a permissão escrita dos proprietários dos direitos autorais. A publicação ou partes dela podem ser reproduzidas para propósito não-comercial na medida em que a origem da publicação, assim como seus autores, seja reconhecida.

ISBN 978-85-99662-52-6

Centro Edelstein de Pesquisas Sociais www.centroedelstein.org.br

Rua Visconde de Pirajá, 330/1205

Ipanema - Rio de Janeiro - RJ

CEP: 22410-000. Brasil

Contato: bvce@centroedelstein.org.br 


\section{ÍNDICE}

Agradecimentos $\quad 03$

$\begin{array}{ll}\text { Introdução } & 04\end{array}$

1. Os Ovos das Galinhas de Ouro:

Internacionalização de um Setor Agropecuário no Brasil $\quad 06$

$\begin{array}{ll}1.1 \text { As origens } & 06\end{array}$

$1.2 \mathrm{O}$ complexo avícola industrial 07

Produção avícola e controle genético 07

Rações $\quad 10$

Produtos químicos 14

A batedouros e frigoríficos $\quad 15$

Máquinas e implementos 16

$\begin{array}{ll}\text { Pesquisa } & 16\end{array}$

1.3 Consumo interno e exportações 18

$\begin{array}{ll}1.4 \text { Conclusões } & 21\end{array}$

2. Capitais, Frangos e Camponeses $\quad 23$

2.1 Formas de produção rural

2.2 Produção agrícola integrada: Santa Catarina 25

As integradoras $\quad 25$

Os produtores avícolas $\quad 29$

Relação integrador/integrado 31

2.3 Produtores não-integrados: o caso mineiro $\quad 35$

As origens $\quad 35$

Estratificação dos produtores

Instabilidade dos produtores $\quad 39$

A intermediação em Minas 47

2.4 Transformações da empresa familiar pela agroindústria $\quad 52$

Processo de trabalho e apropriação do conhecimento camponês $\quad 52$

O sentido da integração $\quad 53$

Seleção - concentração - expulsão

\section{Entre o Ovo e a Galinha:}

Intermediação e Representação Política na Avicultura Brasileira 59

3.1 Articulação Estado/economia

3.2 Instrumentos básicos de realização de interesses $\quad 62$

O crédito $\quad 63$

$\begin{array}{ll}\text { Os preços administrativos } & 68\end{array}$

$\begin{array}{ll}\text { A política de exportação } & 72\end{array}$

Pesquisa e assistência técnica $\quad 73$

3.3 Associativismo, representação e exercício do poder 77

$\begin{array}{ll}\text { Associativismo do capital } & 78\end{array}$

Associativismo do trabalho $\quad 90$

4. Conclusões $\quad 96$

$\begin{array}{lr}\text { Bibliografia Citada } & 99\end{array}$

Apêndice: Contrato de compra e venda em forma de Integração 101 


\section{AGRADECIMENTOS}

Apesar do grande número de pessoas que colaboraram na elaboração deste estudo através de entrevistas, devemos expressar nosso agradecimento a algumas delas em particular. Merivaldo Ferreira Damacena, com seus conhecimentos sobre o tema, e Evandro de Abreu Fernandes, como coordenador de avicultura da Emater/MG, foram de grande valia. O primeiro fornecendo apoio e indicações nos primeiros passos da pesquisa, e o segundo, ajudando a esclarecer certos aspectos da avicultura mineira. 0 mesmo se diga do professor Dinarte Belato, intercambiando idéias e informações sobre a avicultura no Sul. Nenhum deles, entretanto, é responsável por enganos possivelmente cometidos nas análises aqui feitas. Além da eficiência na administração da pesquisa e datilografia do texto, Edna de Figueiredo Lage colaborou com seu bom humor para superarmos os momentos de desânimo. Somos gratos, finalmente, ao Comitê de Ciências Sociais da Fundação Ford, que acreditou serem frangos e ovos tema relevante de pesquisa.

Às aves e outros inocentes animais, enjaulados e neurotizados, dedicamos este livro.

Belo Horizonte, 1981 


\section{INTRODUÇÃO ${ }^{1}$}

O processo de internacionalização da economia brasileira tem sido um fenômeno profusamente analisado e discutido na última década nas ciências sociais. Grande parte dessas análises, porém, tem-se concentrado em torno do processo de internacionalização no setor urbanoindustrial, pouco tendo sido escrito em relação à agricultura. ${ }^{2}$ Inclusive, parte do debate em torno da internacionalização do setor agrícola tem enfatizado o fenômeno de compras de terras por estrangeiros, o que, embora se tratando de uni fato relevante, pouco em si tem a ver com a questão da internacionalização do capital na agricultura. As origens dessa defasagem podem ser relacionadas, em primeiro lugar, à identificação do processo produtivo na agricultura em forma restrita à propriedade da terra e, em segundo lugar, à idéia de que a agricultura brasileira ainda se caracterizaria pela dinâmica das formas tradicionais de produção.

Em trabalhos anteriores, procuramos mostrar como, na verdade, o complexo agroindustrial é componente básico do processo de produção de setores crescentes da agricultura brasileira, e que, portanto, o ciclo produtivo agrícola passa pela indústria de transformação de insumos e de máquinas agrícolas, assim como pela indústria de processamento. $\mathrm{O}$ processo de internacionalização do capital no setor agrícola significa, fundamentalmente, a interiorização dos processos produtivos desenvolvidos nos países capitalistas avançados, veiculados pelas grandes empresas multinacionais ligadas ao setor agroindustrial. Esse processo independe do controle direto da terra pelas multinacionais ou pelo capital agroindustrial em geral.

$\mathrm{Na}$ verdade, parte considerável do pensamento crítico brasileiro, no que se refere aos estudos rurais, concentrou-se na década passada na demonstração dos limites da visão dualista que postulava um Brasil tradicional, fundamentalmente agrário, contraposto a um Brasil moderno, urbano-industrial. A crítica procurou mostrar que, na realidade, o chamado setor tradicional estava articulado ao setor moderno, servindo ao processo de acumulação de capital, especialmente através de mecanismo de oferta de alimentos a preços baixos, além de ser uma fonte geradora de força de trabalho.

Essas análises, sem dúvida corretas, ficaram porém, de certa forma, dentro do marco da proposta criticada. O setor agrícola tradicional também estava destinado a se integrar, de maneira mais profunda, ao processo capitalista. Se as formas tradicionais de produção foram mobilizadas em

\footnotetext{
${ }^{1}$ A pesquisa que deu origem a este trabalho foi realizada entre 1980 e 1981, com o apoio de uma bolsa do Comitê de Ciências Sociais, da Fundação Ford.

${ }^{2}$ Para um primeiro levantamento sistemático sobre a presença do capital estrangeiro na agricultura, ver Sampaio, P. (1979).
} 
certo momento para apoiar o esforço de acumulação, elas mesmas estavam condenadas a serem transformadas, na medida em que o setor agrícola se transformasse num campo de valorização do capital industrial. E esse processo no Brasil se desencadeia claramente a partir da década de 1970.

O processo de internacionalização da agricultura brasileira pode ser enfocado de vários pontos de vista (transferência de tecnologia, reorganização da divisão mundial do trabalho, estratégias empresariais etc.). No presente trabalho, nosso foco central de interesse se restringe aos efeitos da presença da agroindústria na reorganização da produção, nas formas de representação política e nas relações sociais no campo.

O estudo de caso que escolhemos para esta análise é o setor avícola. Este setor se caracteriza, em relação a outros produtos agropecuários:

1) pelo altíssimo grau em que a produção rural se encontra transformada e subordinada à moderna tecnologia produzida pelo complexo agroindustrial, fazendo com que o complexo avícola seja um campo privilegiado para a análise das transformações das relações sociais no campo sob a liderança do capital industrial.

2) por ter sofrido um crescimento vertiginoso, no bojo da expansão do conjunto do setor agroindustrial, baseado, em boa parte, em tecnologia estrangeira, possibilitando, desse modo, esclarecer certos problemas de caráter do setor agroindustrial, suas perspectivas, e a inserção do Brasil no mercado mundial de produtos alimentícios;

3) por permitir analisar os problemas da representação política das novas camadas sociais de produtores rurais ligados ao complexo agroindustrial e que se distinguem claramente dos antigos produtores agrícolas.

Este trabalho se divide em três partes. Na primeira, mostramos os componentes do complexo agroindustrial, com exceção dos produtores avícolas rurais. A análise mostra a articulação entre a instalação do complexo avícola com a importação de tecnologia dos países capitalistas avançados e a importância das multinacionais instaladas no país. Na segunda parte, analisamos as formas de relacionamento dos produtores rurais com as grandes empresas e setores do complexo agroindustrial. Finalmente, na terceira parte, estudamos as formas de representação política que caracterizam os diferentes setores integrantes do complexo avícola. 


\section{CAPÍTULO 1}

\section{OS OVOS DA GALINHA DE OURO: INTERNACIONALIZAÇÃO DE UM SETOR AGROPECUÁRIO NO BRASIL}

\subsection{AS ORIGENS}

Quando se analisa a instalação do complexo avícola no Brasil, devem-se reconhecer as características que possibilitaram sua rápida difusão e implantação no país, diferentemente do que acontece com outros produtos agropecuários. A avicultura, dado seu alto grau de controle do processo biológico, pois este é realizado em condições quase que artificiais, tem um grau muito pequeno de dependência das condições naturais (qualidade de solo e clima), o que é característica da maior parte da tecnologia de produtos agropecuários. Essas condições fazem com que a transferência de tecnologia na agricultura seja problemática, exigindo modificações e pesquisas específicas para adotar técnicas agrícolas, inclusive dentro de um mesmo país ou região.

Sem dúvida, a avicultura pode ser afetada por modificações relevantes de clima, porém, inclusive isso pode ser controlado pelo isolamento térmico e pelo controle das patologias ligadas a novas condições de produção. Assim, a avicultura constitui, sem dúvida, um setor agropecuário onde a transferência de tecnologia pode ser realizada sem maiores dificuldades.

Unia outra característica da avicultura moderna é que ela atingiu um grau muito alto de produtividade, frente à qual dificilmente pode conviver uma avicultura comercial que não se adapte aos padrões técnicos atingidos. Por sua vez, a avicultura tradicional fica rapidamente marginalizada, em face da avicultura industrial, pela incapacidade de produzir nas condições de qualidade, controle sanitário e quantidade regular que impõem os setores de processamento e comercialização avícola.

O moderno complexo avícola brasileiro tem pouco mais de duas décadas, sendo que seu crescimento acelerado se deu fundamentalmente na década de 1970. Esse crescimento demonstra que, mais que substituir a antiga produção - o que também aconteceu -, o complexo avícola criou seu próprio mercado, pelo aumento fantástico de sua produção e transformação da carne de frango num produto de crescente importância na dieta do brasileiro.

A avicultura industrial no Brasil pode ter corno marco inicial, em termos de data, o final da década de 1950, quando substituiu a antiga avicultura comercial que começara nos anos 1920 e 1930. ${ }^{3}$ Foi naquela década que começaram a ser estruturados os novos galinheiros, com novos métodos de manejo, ao mesmo tempo em que o Instituto Biológico de São Paulo, entre outros,

\footnotetext{
${ }^{3}$ Se bem que também esta era estreitamente dependente das linhagens e insumos veterinários importados.
} 
começou a ter unia intensa atuação no sentido da melhoria no combate às doenças e do controle sanitário em geral, juntamente com o surgimento das primeiras associações de avicultores e cooperativas.

O impulso a esse tipo de produtor deveu-se em boa parte à implantação do programa de "galpões de mil frangos", e se dá juntamente com a instalação no Brasil, em 1963, de nove filiais de empresas dos Estados Unidos, trazendo suas linhagens de "avós" para a produção local de matrizes. Anteriormente, a partir da década de 1940, a produção de matrizes no Brasil era feita pela importação de "avós" por empresas nacionais, através da concessão de empresas estrangeiras.

Com a interiorização crescente no Brasil da produção de avós, a partir de 1963, por empresas estrangeiras, o Decreto n9 55.981, de 22 de abril de 1965, veio disciplinar a importação de avós e aves para reprodução no Brasil. A partir de tal decreto, deixou-se de importar matrizes, que passaram a ser produzidas internamente e, em conseqüência, o setor avícola especializou-se em granjas de aves "avós", de matrizes e de produção final. Em 1973, já existiam 18 empresas produtoras de matrizes no Brasil, nove das quais eram empresas estrangeiras operando diretamente no país e uma firma trabalhando com linhagem própria, a Granja Guanabara. Em 1980 existiam no Brasil 35 linhagens ou "marcas" diferentes de aves, sendo 32 estrangeiras e três brasileiras: 12 linhagens de corte, 12 de postura de ovos brancos e 11 de postura de ovos vermelhos. Das 32 estrangeiras, 19 eram dos Estados Unidos, cinco do Japão, três do Canadá, três da Holanda, uma da Inglaterra e uma de Israel (BDMG, 1979, pp. 13-14).

\subsection{O COMPLEXO AVÍCOLA INDUSTRIAL}

\subsubsection{PRODUÇÃO AVÍCOLA E CONTROLE GENÉTICO}

O cerne da produção avícola industrial, que determina o conjunto de processos posteriores de alimentação e cuidados, está no domínio genético. Essa avicultura se funda na criação de raças que conseguem a máxima capacidade de transformação de cereais em carne, no mínimo de tempo. O frango é, dentre os animais produtores de carnes para o consumo humano, aquele com maior capacidade de transformação de cereais para produzir carne no menor tempo possível. No caso brasileiro, o rateio médio é de $2 \mathrm{~kg}$ de cereal para $1 \mathrm{~kg}$ de carne num período de 56 dias, bastante próximo das médias alcançadas nos países capitalistas avançados. Relação similar existe quanto às galinhas poedeiras que provêm de linhagem totalmente diferente das aves de corte - em termos de transformação de ração em ovos, durante um período de tempo determinado.

As aves que atingem esses níveis de produtividade são geradas a partir de linhagens puras, controladas a partir de bancos genéticos. Tanto o frango de corte corno as galinhas poedeiras são produto de cruzamento de suas avós, de linhagem pura, que serão consumidas na terceira geração 
quando atingem os níveis ideais de produtividade. É impossível, a partir dos descendentes, recriar as linhagens puras de origem. Dessa forma, a venda de avós não impede os proprietários das raças de continuarem mantendo o controle destas.

A avicultura geneticamente controlada deu lugar à moderna produção industrial de frangos que se expande aceleradamente a partir do pós-guerra nos Estados Unidos, Europa e Japão. Em todos esses países (e em Israel) são produzidas raças com qualidades genéticas mais ou menos similares. Os Estados Unidos, porém, são o país com maior número de raças e o maior produtor mundial de frangos.

Em torno do frango geneticamente controlado desenvolveram-se as pesquisas de alimentação e patologia avícola, de forma a permitir a sua produção industrial em recintos em que o manuseio e a alimentação passaram a ser realizados em termos das exigências da produção em bases empresariais. Essas exigências significam fundamentalmente a eliminação de desperdício de ração, diminuição de uso de mão-de-obra pela crescente mecanização de tarefas e maximização do uso de espaço e rotação do capital fixo. ${ }^{4}$

Com o surgimento no Brasil do moderno complexo avícola, se dá a importação maciça de novas linhagens, primeiro matrizes e depois avós. Em 1961 chegaram os primeiros exemplares de matrizes dos Estados Unidos para o Brasil numa operação entre Robert Parks e a Granja Branca (GB). Em 1962 a Granja Guanabara (RJ) trouxe Shaver do Canadá. Mais tarde a empresa norteamericana Arbor Acres adquiriu a Granja Regina em Rio Claro (SP), o que foi seguido por outras empresas. Para assegurar o controle tecnológico ou genético, no início "(...) vinham para o Brasil apenas as matrizes. Alguns dos concessionários conseguiram logo bisavós e avós; mas a maioria recebia somente aquelas. Essa dependência contrariava nossos interesses; por isso, depois de muitos debates, ela foi proibida a partir de janeiro de 1968. Mas continua sendo concedida a importação de reprodutores de alta linhagem, para prosseguimento ou manutenção das hibridações das grandes marcas" (Dirigente Rural, abril de 1969, p. 51). Com essa transferência, através da importação de matrizes e, mais tarde, de avós, e a produção de matrizes no Brasil pelas grandes empresas ligadas ao setor, praticamente existem no Brasil todas as linhagens principais.

"Em decorrência do melhor conhecimento das moléstias, foram fundados vários laboratórios de vacinas e vieram para o Brasil algumas empresas estrangeiras com suas linhas de produtos veterinários para aves" (Dirigente Rural, abril de 1969, p. 50). Nessa época começaram os primeiros contatos com a tecnologia norte-americana, que mais tarde seria a principal fornecedora tanto de material genético quanto de insumos químicos. "Em 1958, pela primeira vez, uma delegação

\footnotetext{
${ }^{4}$ Sobre esses aspectos, ver o próximo capítulo.
} 
brasileira participou de uni Congresso Mundial de Avicultura." (...) "No ano anterior e prosseguindo por mais dois ou três - viajaram para os Estados Unidos da América alguns avicultores e técnicos brasileiros, sob o patrocínio da Comissão Nacional de Avicultura e do Projeto ETA-42, ambos dirigidos pelo engenheiro agrônomo Mario Vilhena" (Dirigente Rural, abril de 1969, p. 50). "Em 1961, três técnicos gaúchos participaram, com outros técnicos brasileiros, de uni estágio de 90 dias nos Estados Unidos sobre avicultura" (Araújo, 1976, p. 11). O grande crescimento da produção se deu, porém, na década de 1970, conforme aparece no Quadro 1.1.

Quadro 1.1

Produção brasileira de matrizes para corte e frangos

\begin{tabular}{lccc}
\hline Ano & Matrizes & Aves vivas (milhöes) & Aves abatidas (1.000t) \\
\hline 1971 & 3.114 .463 & 160 & 224 \\
1972 & 3.905 .843 & 210 & 294 \\
1973 & 3.907 .234 & 285 & 401 \\
1974 & 5.280 .646 & 310 & 434 \\
1975 & 4.727 .338 & 343 & 484 \\
1976 & 5.956 .861 & 394 & 551,6 \\
1977 & 6.310 .788 & 451 & 631,5 \\
1978 & 7.319 .962 & 552 & 840 \\
1979 & 8.768 .209 & $750^{\mathrm{a}}$ & $1.019^{\mathrm{a}}$ \\
1980 & 11.973 .464 & $880^{\mathrm{b}}$ & $1.240^{\mathrm{b}}$ \\
\hline
\end{tabular}

a Estimativa.

b Previsão.

Fonte: Realidade Agroavicola, dezembro de 1980.

Em 1969, as principais linhagens para corte no Brasil eram: Anake (Israel), Arbor Acres, Cobb, Carolina (Brasil), de Kalb, Garrison, Holzgrafe, Hubbard, Indian River (da Hy-Line), Kimber Nest Nick Parks, Shaver Starbro (canadense) ${ }^{5}$ e Welp Line. Para postura, Babcok, Brownegger, Brow Nick, de Kolb, Harco, Honeger, Hy-Line, Keystone-Parks, Nick Chick, Piloh, Pedi-Link, Shaver Starerosse e Welp Line (Dirigente Rural, abril de 1969, p. 52).

As grandes importadoras de avós (que chegam ao país com dois ou três dias de vida) vendem as matrizes produzidas pelo cruzamento para grandes granjas ou integradoras, ou produzem diretamente as poedeiras e frangos de corte que serão vendidos aos produtores avícolas.

Atualmente, algumas das principais empresas controlam o desenvolvimento genético, a partir de suas relações com a produção internacional. A Granja Eldorado Agro Avícola Ltda. (SP) é representante da Poultry Breeden Union (Israel) e proprietária da linhagem Anak e Iamiv para toda a América Latina e teve uni grande crescimento entre 1970-1981 (Avicultura Industrial, n9 850, pp. 7-10 e Dirigente Rural, p. 13 (8/9), novembro de 1974, pp. 42 e 55). A Ito (SP) representa para a

\footnotetext{
${ }^{5}$ Posteriormente comprada pela Cargill.
} 
América Latina as linhagens Hy-Line (produção de ovos) e Indian River (corte) e realiza melhoramentos genéticos com linhagens híbridas (Avicultura Industrial, $n^{\circ}$ 853, pp. 4 e 55). A Granja Rezende, em Uberlândia (MMG), detém 40\% do mercado brasileiro de matrizes, e assinou contrato em 1979 para a importação das marcas Hubbard e Petersson dos Estados Unidos, gastando em 1980 cerca de 2 milhões de dólares com a importação de avós (Dirigente Rural, maio de 1980, pp. 2325).

Em 1976, foram importadas 450 mil matrizes avós e 68,7 mil ovos férteis para matrizes avós, representando cerca de 1,5 milhão de dólares, principalmente dos EUA, Israel, Inglaterra, Holanda e Canadá. É importante notar que, visto que boa parte das empresas que importam e controlam as avós no Brasil são responsáveis por toda a América Latina, em 1976 o Brasil exportou 385 mil dólares em pintos de um dia, matrizes avós e ovos fertilizados para países latinoamericanos, em especial Argentina, Bolívia, Uruguai, Chile, Colômbia e Paraguai (MMA/Suplan, Brasília, p. 63).

A Granja Guanabara possui um trabalho próprio de reprodução e melhoramento genético. É a única empresa no Brasil e na América Latina que produz suas próprias matrizes, das linhagens G307 e G-05 (produção de ovos) e G-201 (corte). Com exceção desse caso, toda a produção de avós é importada (A Granja, janeiro de 1981). Embora tenha havido em fins da década de 1960 uma primeira tentativa do governo para introduzir a produção de linhagens, a produção brasileira é ainda pouco relevante. A Granja Guanabara, a única a produzir uma linhagem internamente, tem hoje uma participação de $5 \%$ no mercado. ${ }^{6}$ De qualquer maneira, existem indicações de que, quando for do interesse dos produtores estrangeiros ou pressionados para tanto, eles terão capacidade de passar a produzir linhagens puras no Brasil. Essa interiorização poderia em certos casos se dar, inclusive, a partir de urna integração com capitais nacionais ligados às grandes granjas ou abatedouros.

\subsubsection{RAÇÕES}

A primeira empresa multinacional vinculada à produção de ração a se instalar no país foi a Purina, que, além de oferecer uma gama de insumos básicos, montou desde o começo um plano de assistência aos produtores, já testado em outros países. A seguir, veio outra empresa de capital norte-americano, a Cargill, que atua também na transformação de milho e soja, seguida pela Anderson Clayton, que tem na comercialização da soja seu principal campo de interesse no Brasil. $\mathrm{Na}$ década de 1960, as principais empresas de capital predominantemente nacional que tinham interesses ligados à produção de rações eram a Anhanguera, Avisco, Grangeiro, Moinho

\footnotetext{
${ }^{6}$ Em 1980 foram importadas em torno de 100 mil avós ao preço médio de 50 dólares a unidade.
} 
Fluminense, Moinho da Luz, Socil e algumas das grandes cooperativas agrícolas (Dirigente Rural, abril de 1969, p. 54). Essas empresas, em sua maioria, passaram mais tarde a expandir suas atividades para outras regiões do país e, em boa parte, entraram em associação com o capital externo. Na atualidade, a Cargill é a principal empresa no setor de rações avícolas seguida pela Purina, ambas norte-americanas. ${ }^{7}$

Na produção de rações, é necessário examinar separadamente os blocos diversos de capital que produzem os vários componentes da ração e que possuem estrutura própria. Assim, os produtores dos aditivos químicos, que requerem uma tecnologia mais sofisticada e estão vinculados à tecnologia químico-veterinária, recebem seu fornecimento de insumos das mesmas empresas produtoras de produtos veterinários, quando não importam diretamente. Os principais fornecedores desses aditivos são a Bayer do Brasil, Comércio e Indústria Sétimo Céu, Cia. Brasileira de Rações CBR, Cosmoquímica Ind. e Com., Diprovet, Englert Nutrimentos, Exatil Nutrimentos, For-Agro, Formulações Agropecuárias, Granja Guanabara, Granja Letícia, Laboratório Isa, Laboratório Prado, Minosa S.A., Ind. Milhos e óleos Vegetais, Moinho Cruzeiro do Sul, Montedison Farmacêutica, Nutripal Ind. e Com., Rações Criador Ind. e Com., Rações Fri Ribe, Sivon - Cia. de Produtos para Fomento Agropecuário, Socil Pró-Pecuária, Sumaré Ind. e Com. de Rações e Derivados e Usina Colombiana (A Granja, Edição Especial, 1979).

Boa parte dessas mesmas empresas produtoras de aditivos são responsáveis também por parte da oferta de rações de diversos tipos para o mercado nacional. Contudo, a maioria das empresas fornecedoras de rações estão mais estreitamente vinculadas a grandes moinhos que propriamente à produção de aditivos químicos, se bem que na produção de rações esses dois blocos de capital se cruzam. A vinculação entre empresas produtoras de rações com os grandes moinhos (um dos setores mais oligopolizados) é devida ao fato de que os subprodutos desses moinhos são os principais ingredientes quanto ao peso da ração. Assim, cerca de 70-80\% do peso da ração resultam de subprodutos de milho, trigo, arroz e soja.

A produção de rações na década de 1970, no Brasil, quintuplicou, como mostra o Quadro 1.2, sendo que, segundo estimativas, mais de $60 \%$, dessa produção destinam-se à avicultura (BDMG, p. 3).

A produção de milho, elemento de maior peso dentro das rações (em torno de $70 \%$ do peso

\footnotetext{
${ }^{7}$ Cargill, a mais importante produtora de rações para o setor avícola, atua nos diversos ramos do setor agropecuário. De acordo com um folheto de publicidade da empresa, a Cargill do Brasil, instalada em 1965, começou suas atividades no setor das sementes de milho híbrido. Em 1980 ela possuía vários terminais graneleiros e terminais marítimos, fábricas de rações para gado, suínos e aves, fábrica industrializadora de cacau, fábrica de alimentos para cães, fábrica de óleo, usina de beneficiamento e centros de pesquisa de sementes, granja e encubatório (a Cargill é proprietária da linhagem Shaver, a mais importante matriz de poedeiras no mercado), fábrica de suco cítrico, fábrica de processamento de aves, usina de beneficiamento de algodão e fábricas de óleos.
} 
físico e $50 \%$ de seu custo, em 1981), ${ }^{8}$ ainda é realizada em bases relativamente tradicionais. 0 milho pode, na verdade, ser considerado um produto "transicional", no qual somente parte da produção, ainda pequena, é realizada com métodos modernos (uso de sementes híbridas, adubos químicos etc.) e outra em bases tradicionais. O crescimento da demanda causada pela avicultura está pressionando na direção de uma rápida modernização deste setor.

Por sua vez, o capital produtor de rações é vinculado aos grandes moinhos e à comercialização internacional de trigo, soja e seus derivados, um dos setores mais internacionalizados da economia brasileira, cujos representantes do capital externo são a Anderson Clayton (norte-americana), Central Soya Alimentos (idem), Cargill Agrícola (idem) e a série de moinhos em boa medida com controle acionário ou participação da Bung y Born. A Agroceres, unia das maiores produtoras de rações no Brasil, até 1980 era constituída de capital norte-americano da família Rockefeller, com 64\% das ações. A partir de novembro de 1980 teve $91 \%$ de seu controle acionário vendidos a grupos brasileiros. (Anuário Suinícola, 1980, pp. 4-10).

O grupo de empresas produtoras ou distribuidoras de rações, não-vinculadas aos grandes produtores de insumos químico-veterinários nem aos grandes moinhos comercializadores de trigo e soja, é composto por empresas tanto dedicadas exclusivamente à produção de rações como revendedoras de insumos genéticos, como a Granja Guanabara, Granja Letícia e as Cooperativas.

$\mathrm{Na}$ medida, porém, em que a produção dos concentrados (que misturados com milho produzem a ração) tem suas exigências quanto à tecnologia e ao montante de capital na fase de produção dos componentes básicos (químico-veterinários e resíduos de moinhos e frigoríficos), eles são produzidos por grandes empresas. Por outro lado, a produção da ração como tal é relativamente simples, uma vez obtidos os concentrados, possibilitando a formação de empresas de médio e até pequeno porte neste ramo, que adquirem matéria-prima para a mistura. No Rio Grande do Sul, por exemplo, em 1976, existiam cerca de 62 fábricas de rações, boa parte composta por pequenas e médias empresas, como pequenos moinhos, cooperativas agrícolas etc., ao lado de grandes empresas integradoras de suínos e aves (Roani, 1977, p. 44).

As grandes empresas de rações trabalham tanto ao nível de venda direta de rações elaboradas aos produtores, através dos postos de vendas, como venda de concentrados a pequenas e médias empresas e produtores que misturam a própria ração na granja.

Em 1980, a Asashi Chemical, do Japão, lançou no Brasil sua linha de antibióticos para ração animal. Nesse mesmo ano, a Cargill inaugurou em Maringá (PR) sua 11 á fábrica de rações, com

\footnotetext{
${ }^{8}$ Os outros $30 \%$ estão compostos por farinhas (de carne, peixe, soja etc.) e ingredientes químicos, formando os "concentrados".
} 
capacidade de 15 mil t/mês, para produção de rações prontas e concentradas para suínos, aves, bovinos etc., visando o mercado do Paraná, Santa Catarina, Mato Grosso do Sul e Alta Sorocaba (SP). Por sua vez, a Anderson Clayton, tendo em vista a expansão do mercado interno de produtos básicos de alimentação, o aumento da produção de grãos e o mercado externo favorável, programou para 1981 investimentos da ordem de 35 milhões de dólares, com o objetivo de aumentar sua capacidade de produção de rações e de processamento de soja e caroço de algodão (A Granja Avícola, maio de 1980, p. 26; março de 1981, p. 12 e Correio Serrano, 15 de março de 1981, p. 7).

Na produção de rações para aves, os principais fornecedores no Brasil em 1979 eram: Agroceres, P.C. Melhoramentos de Suínos, Anderson Clayton S.A. Ind. e Com., Aduras Adubos, Rações e Derivados, Aviário Mocopar, Avipal, Avisco - Avicultura Com. e Ind., Cargill Agrícola, Casp S.A. Ind. e Com., Central Soya Alimentos, Diprovet, Englert Nutrição Animal, Exatil Nutrimentos, Granja Guanabara, Granja Letícia, Indústria Avícola Caxias, Jollymar S.A. Integração Agropecuária, Cattani Emer \& Cia., Cia. Brasileira de Rações - CBR, Cooperativa Agrícola de Cotia, Cooperativa Agropecuária Halambra, Cooperativa Avícola Vale do Taquari, Cooperativa Central Agrícola de São Paulo, Mogiana Alimentos, Moinho Atlântico, Moinhos Cruzeiro do Sul, Moinhos Germani S.A. - Fábrica de Rações, Nutripal - Nutrimentos Portoalegrense, Nutrição Ind. e Com. de Nutrimentos para Animais e Agropecuária, Produtos Alimentários Corcetti S.A. Ind. e Com., Rações Dutra, Rações Barriga Verde S.A. Ind. e Com., Rações Criador Ind. e Com., Rações Fri Ribe, S.A. Moinho Santista Ind. Gerais, Suely Rações e Yak Equipamentos (Quem é quem na agropecuária brasileira - A Granja, edição de 1979, pp. 19394).

Desse modo, a internacionalização e oligopolização do capital no tocante à produção de rações diz respeito em especial à produção de seus componentes, tanto aditivos químicoveterinários quanto industriais de milho, soja, trigo, arroz, cuja indústria de processamento já está fortemente internacionalizada e oligopolizada. $\mathrm{O}$ processamento da mistura dos componentes requer pouca tecnologia e centralização do capital e, por isso, é, em boa medida, feito por pequenas e médias empresas de capital nacional, quando não pelos próprios moinhos, produtores de insumos químico veterinários, ou empresas integradoras. Evidentemente isso pode ser também decorrente do fato de ser recente o mercado nacional de rações ou, pelo menos, sua expansão. Possivelmente, com a consolidação da avicultura e suinocultura industrial e com o aumento do consumo desses insumos pela pecuária leiteira, os principais produtores de rações, pelo menos para aves e suínos, serão as empresas integradoras através da aquisição dos aditivos químicos e do milho, soja e outros componentes, estes últimos podendo ser produzidos pelos próprios integrados. 


\subsubsection{PRODUTOS QUÍMICOS}

Os principais laboratórios que entraram na produção de produtos veterinários para a avicultura nas décadas de 1950 e 1960, ou seja, no início da avicultura industrial, eram em sua maior parte controlados pelo capital interno. Mais tarde, e como decorrência da tecnologia sofisticada que utilizam, passaram a contar com capital externo, transformando-se num dos setores mais internacionalizados da economia brasileira, ao lado da produção de cigarros. Nos anos 1960, os principais laboratórios ligados à produção de produtos veterinários eram o Abbott, Ajinomoto, American Cyanamid (Blenco), Boyer, Dow, Dupont, Eaton, Elanco, Fontoura-Wyeth, Seregy, Lepetit, Merck Sharp Dohm, Manguinhos, Pfizer, Rhodia, Squibb, Sabia, Vetifarm e Instituto Biológico de São Paulo (Dirigente Rural, 1969, p. 55).

Graças ao alto grau de centralização e oligopolização, o mesmo grupo de empresas que oferece os produtos veterinários básicos é responsável, fundamentalmente, também por toda a gama de insumos químico-veterinários tanto para a avicultura quanto para as demais linhas de produção pecuária. De acordo com a lista de "produtos e serviços" de Quem é quem na agropecuária brasileira, da revista A Granja de 1979, as mesmas empresas de produtos veterinários abarcam os analgésicos, anaplasmose, anestésicos, avitaminóticos, bactericidas, defensivos contra doenças de animais em geral, complementos minerais para os diversos tipos de animais produtos para a avicultura e, em boa medida, inclusive rações e adubos. Os principais fornecedores dos componentes dessa lista, que em boa parte coincidem com o setor de produtos farmacêuticos e veterinários de Visão, ${ }^{9}$ são a Bayer S.A. (capital alemão), Cyanamid Química do Brasil, Diamond Shamrock do Brasil, Instituto Valée, Laboratório Leite S.A., Indústria Química e Biológica, Minerthal Produtos Agropecuários, Laboratórios Fama, Montedison Farmacêutica, Pfizer Química, Salsbury Laboratórios, Squibb Indústria Química, Syntex do Brasil Ind. e Com., Laboratórios de Produtos Químicos e Veterinários Vigor, Laboratório Quintus, Pearson Ind. e Com., Vitasul, Abbott Laboratórios do Brasil, Anschau Com. e Representações, Ciba-Geigy Química, Diprovet, Elanco Química, INC Usafarma Ind. Farmacêutica, Laboratório Bravet, Laboratórios Noli, Leivas Leite S.A. Ind. Químicas Biológicas, M. Cassale Fenícia Importação e Exportação, Nutrição Ind. e Com. de Nutrimentos para Animais, Química e Farmacêutica Nikkho Brasil, Sivan Comp. de Produtos para Fomento Agropecuário, Tortuga Comp. Zootecnia Agrária, Upjohn Produtos Farmacêuticos,

\footnotetext{
${ }^{9}$ De acordo com a edição de 1979 de Quem é Quem da Visão, o setor de química, que engloba, entre outros, os setores de produtos farmacêuticos, medicinais e veterinários, possuía um patrimônio líquido de 261,8 bilhões de cruzeiros distribuídos entre 422 empresas. As empresas de controle acionário nacional representavam 286, as de controle acionário externo 110 e as estatais 26. Já o subsetor de produtos farmacêuticos e veterinários era formado por 51 empresas, com um patrimônio líquido de 7,1 bilhões de cruzeiros, do qual as 28 empresas de controle acionário nacional privado detinham 33,31/,, as três estatais 3,3\% e as 20 estrangeiras os 63,4\% restantes. (Ver Quem é quem na economia brasileira - Visão, 1979, pp. 254-55.)
} 
Usinas Químicas Brasileiras, Basf Brasileira S.A. - Ind. Químicas, Fatec Química Industrial, Merck Sliarp \& Dohme - Ind. Química Farmacêutica, Dow Química, Ind. Farmacêuticas Fontoura Wyeth, The Sydney Ross Co., e algumas outras.

Essas mesmas empresas fornecem também a maior parte dos produtos de insumos nãoquímico-veterinários, como atreladouros, bebedouros, campânulas, comedouros, classificadores de ovos, misturadores de ração etc., em especial a Anschau Com. e Rep. (Quem é quem na agropecuária brasileira - A Granja, edição de 1979, pp. 175-240 e junho de 1975, p. 65).

Como a produção de insumos químico-veterinários possui uma estrutura com alto grau de oligopolização e um mercado nacional, por isso mesmo, e também por serem produtos de fácil transporte, os insumos consumidos nas diferentes regiões são produzidos em forma centralizada por empresas localizadas em geral em São Paulo e Rio. Os grandes laboratórios vendem seus produtos tanto às indústrias de rações, integradoras, como diretamente aos produtores. Elas também possuem redes próprias de assistência técnica aos produtores através das quais encaminham seus produtos.

\subsubsection{ABATEDOUROS E FRIGORÍFICOS}

A internacionalização do capital de processamento industrial e comercial na produção agrícola, no caso da avicultura industrial, possui alguma especificidade. Esse é um dos setores menos internacionalizados da indústria brasileira. De acordo cone Quem é Quem, de Visão, 1979, o subsetor frigorífico era composto por 101 empresas, das quais 97 de controle acionário do capital privado nacional e quatro estatais (Quem é Quem - Visão, 1979, p. 306). Contudo, deve-se levar em conta que os critérios de Visão para que unia empresa seja considerada de capital externo é que o controle acionário seja majoritário (mais de 50\% das ações) ou integral, com propriedade total das ações. Não se considera, portanto, a participação minoritária, que pode ser mista, ou seja, de capitais nacionais privados, estatais, e/ou estrangeiros (Quem é Quem - Visão, 1979, p. 509). Desse modo, das 101 empresas (sete de capital aberto), boa parte já teve controle acionário de capital externo, e possivelmente, como estratégia frente aos estímulos oficiais, passaram a ter controle acionário local. Os casos mais notáveis nesse sentido são a Swift Armour, com controle acionário de capital norte-americano até há pouco, e a Serrano Indústria Brasileira de Alimentação (do Grupo Herta, de capital alemão), entre outros. A Perdigão (SC), por outro lado, é exemplo de uma empresa nacional que passou a ter participação de capital externo, japonês e árabe.

Como vimos no caso dos produtores de linhagens e como veremos na seção sobre exportações, existiria uma tendência à penetração do capital estrangeiro no setor das grandes empresas integradoras, isto é, as que conjugam abatedouro, frigorífico, industrialização e comercialização. Essa penetração seria a forma mais eficaz de assegurar o controle do mercado de 
consumo de seus produtos.

\subsubsection{MÁQUINAS E IMPLEMENTOS}

Outro setor relativamente internacionalizado, mas de difícil exame no tocante especificamente à avicultura, é a produção de máquinas e implementos, por fazer parte do conjunto de indústrias vinculadas aos setores de produção de máquinas em geral. De qualquer modo, esse setor já atrai capital externo na medida de sua expansão. Em 1980, por exemplo, a Meyen, indústria holandesa de abatedouro avícola, instalou-se no Brasil, para fabricação de abatedouros automáticos de aves com capacidade de $3 \mathrm{mil}$ aves/hora e outros equipamentos. (A Granja Avícola, julho de 1980, p. 24). A primeira empresa estrangeira especializada no setor foi a Big Dutchman.

\subsubsection{PESQUISA}

A pesquisa e produção tecnológica, em particular no tocante à produção de material genético e de insumos químico-veterinários sofisticados, está estreitamente vinculada ao grande capital internacional e, inclusive, é uni elo básico da internacionalização do complexo avícola industrial. A produção e controle genético exemplificam isso, na medida em que está a cargo quase exclusivamente da produção nos maiores centros internacionais do capital e desenvolvimento tecnológico, de onde é importado em sua quase totalidade. Juntamente com o controle genético, é importada, em boa medida, também a tecnologia de manejo e de organização da produção. Já a tecnologia sofisticada de produção de insumos veterinários, se bem que também seja produzida essencialmente nos centros tecnológicos mundiais, em sua maior parte é utilizada pelas empresas produtoras no Brasil, visto que, por ser um setor industrial já consolidado internamente e ao mesmo tempo altamente internacionalizado, a transferência da tecnologia, nesse caso, se dá mais pelas relações entre empresas filiais com as matrizes que propriamente pela compra de insumos. Em outras palavras, a transferência de tecnologia sofisticada, em setores de produção de insumos sofisticados que requerem tecnologia de ponta, como os de origem químico-veterinária, se dá em boa medida juntamente com a transferência de capitais e no relacionamento entre a empresa instalada no Brasil e a matriz.

No caso da produção de material genético, possivelmente por ser mais recente seu consumo em escala no Brasil, a transferência do exterior ainda tem como base a compra. Com exceção de algumas tentativas de desenvolvimento tecnológico voltado para a avicultura da década de 1950 em diante, como o Instituto Biológico de São Paulo, e outras tentativas que não foram além do desenvolvimento e/ou adaptação de tecnologia de manejo, e o caso da produção de linhagens próprias da Granja Guanabara, praticamente toda a tecnologia genética é importada. 
Por outro lado, tudo leva a crer que, se o desenvolvimento do complexo avícola industrial no Brasil continuar nesse ritmo, a exemplo da tecnologia dos demais insumos modernos que requerem tecnologia de ponta, a produção de material genético também poderá se desenvolver ou pelo menos se adaptar internamente. Isso se dará sob o controle das empresas produtoras e detentoras da tecnologia genética, quer através de suas filiais que progressivamente se vão instalando no Brasil, quer através da associação dessas empresas com empresas de origem nacional vinculadas ao complexo avícola industrial e da atuação dos órgãos oficiais e mesmo empresas privadas na adaptação, aperfeiçoamento e difusão daquelas franjas de tecnologia que não compõem a produção básica da tecnologia de ponta sob o controle das corporações internacionais.

A atuação do Estado e das empresas integradoras, embora tenda a se intensificar pela própria dinâmica do complexo avícola industrial e pela importância que possui no conjunto das políticas oficiais, mesmo que tendencialmente avance no sentido da pesquisa e assistência técnica, se caracteriza por atuar fundamentalmente na assistência técnica. Esta consiste no acompanhamento da aplicação tecnológica ou mesmo no desenvolvimento de pesquisas que visam à adaptação de tecnologia de ponta ou pesquisa sobre manejo etc., atingindo apenas tangencialmente a pesquisa mais aplicada. Nesse sentido, desde 1980 e por solicitação de associações dos diversos setores da avicultura industrial, a Embrapa (Empresa Brasileira de Pesquisa Agropecuária) iniciou um Programa de Pesquisa Avícola após simpósio de três dias com representantes de entidades associativas e instituições de ensino superior e de órgãos das secretarias de agricultura dos principais Estados produtores. O conteúdo principal do Programa consiste em adaptação tecnológica de estirpes de aves e maior eficiência em sanidade, nutrição, manejo, comercialização etc. (Avicultura Industrial, novembro de 1980, p. 16).

Nos Estados, o entrosamento principal se dá entre órgãos de pesquisa e assistência das secretarias de agricultura e universidades. Estas últimas, como no caso de Minas, foram importantes na divulgação de técnicas de manejo assim como no incentivo a empresários a entrarem no setor. (Avicultura Industrial, agosto de 1979, pp. 5-12). Por outro lado, enquanto a assistência técnica à massa de produtores diretos é feita diretamente pelas empresas integradoras em Estados, como Santa Catarina, onde predomina a integração por contrato, em outros, como é o caso de Minas Gerais, onde a produção não se organiza em tais moldes, mas onde predominam os produtores isolados, parece que essa assistência é em boa parte subsidiada pelo poder público, especialmente através da Emater, Empresa de Assistência Técnica e Extensão Rural. A filosofia da Emater, nesse caso, é "difundir tecnologia agropecuária e gerencial, gerada por escolas e outros órgãos públicos, operacionalizando-a a nível de produtor individualmente" (ibid., pp. 33-34). 


\subsection{CONSUMO INTERNO E EXPORTAÇÕES}

O consumo do frango "industrial" produziu modificações nos hábitos de consumo popular. Anteriormente, o frango "caipira" era o preferido pelo consumidor, que considerava o frango industrial com sua pele muito branca, sem gorduras, um frango inferior. 0 frango industrial impõese primeiro nos supermercados, e com um público fundamentalmente de classe média. Com o tempo, seja pela sua oferta sistemática na maioria dos centros de vendas de carnes, seja pelo preço relativamente inferior à carne de boi, terminou por ingressar inclusive no consumo popular. ${ }^{10}$

\section{Quadro 1.3}

Relação de preço bovino, frango, suíno salário trabalhador urbano e rural, São Paulo, 1970-1980

\begin{tabular}{lllllll}
\hline Ano & $\begin{array}{c}\text { Bovino } \\
\text { salário } \\
\text { urbano }\end{array}$ & $\begin{array}{c}\text { Frango } \\
\text { salário } \\
\text { urbano }\end{array}$ & $\begin{array}{c}\text { Suíno } \\
\text { salário } \\
\text { urbano }\end{array}$ & $\begin{array}{c}\text { Bovino } \\
\text { salário } \\
\text { rural }\end{array}$ & $\begin{array}{c}\text { Frango } \\
\text { salário } \\
\text { rural }\end{array}$ & $\begin{array}{c}\text { Suíno } \\
\text { salário } \\
\text { rural }\end{array}$ \\
\hline 1970 & 1,00 & 1,00 & 1,00 & 1,00 & 1,00 & 1,00 \\
1971 & 1,16 & 0,95 & 0,96 & 1,11 & 0,91 & 0,92 \\
1972 & 1,29 & 0,92 & 1,06 & 1,12 & 0,80 & 0,92 \\
1973 & 1,57 & 1,18 & 1,12 & 1,24 & 0,93 & 0,89 \\
1974 & 1,75 & 1,12 & 1,74 & 1,09 & 0,70 & 1,08 \\
1975 & 1,32 & 0,95 & 1,21 & 0,90 & 0,64 & 0,82 \\
1976 & 1,14 & 0,86 & 0,98 & 0,77 & 0,58 & 0,67 \\
1977 & 1,10 & 0,79 & 1,06 & 0,70 & 0,50 & 0,67 \\
1978 & 1,42 & 0,82 & 1,04 & 0,92 & 0,53 & 0,68 \\
1979 & 1,58 & 0,72 & 1,05 & 1,31 & 0,60 & 0,87 \\
1980 & $1,53^{\mathrm{a}}$ & $0,75^{\mathrm{a}}$ & $1,12^{\mathrm{a}}$ & $1,16 \mathrm{~b}$ & $0,57 \mathrm{~b}$ & $0,85^{\mathrm{b}}$ \\
\hline
\end{tabular}

a Valores de maio.

b Valores de abril.

Fonte: Instituto de Economia Agrícola - Banco Central do Brasil, in Suinocultura Industrial, n? 32, ano 4, 1981.

\footnotetext{
${ }^{10}$ Uni ditado popular dizia que pobre só come frango quando uni dos dois está doente. Na atualidade, o consumo de frango caipira só é relevante, na produção rural, para autoconsumo.
} 
Quadro 1.4

Brasil - produção per capita de carnes bovina, avícola, suinícola $(\mathrm{kg} / \mathrm{hab})-1970-1979$

\begin{tabular}{lccc}
\hline Ano & $\begin{array}{c}\text { Carne } \\
\text { bovina }\end{array}$ & $\begin{array}{c}\text { Carne } \\
\text { avicola }\end{array}$ & $\begin{array}{c}\text { Carne } \\
\text { suinicola }\end{array}$ \\
\hline 1970 & 22,2 & 2,3 & 7,6 \\
1971 & 22,3 & 2,3 & 7,8 \\
1972 & 22,8 & 3,0 & 7,1 \\
1973 & 23,2 & 4,0 & 7,9 \\
1974 & 24,0 & 4,2 & 7,6 \\
1975 & 24,5 & 4,5 & 8,8 \\
1976 & 23,1 & 5,0 & 9,6 \\
1977 & 22,8 & 6,1 & 8,8 \\
1978 & 22,1 & 7,4 & 8,6 \\
1979 & 23,3 & 8,4 & 7,5 \\
\hline
\end{tabular}

Fonte: UBA, FJP/GIA, MA, IBGE, in Suinocultura Industrial, nọ 32, ano 4, 1980.

Na década de 1970, enquanto o consumo e estoque de suínos e bovinos apenas cresceu, a produção avícola per capita quase quadriplicou.

\section{Quadro 1.5}

Quantidade de carne $(\mathrm{kg})$ adquirida no varejo

pelo salário mínimo mensal - (1971 a 1979 - São Paulo ) + 13ọ salário

\begin{tabular}{lccc}
\hline Ano & Boi $(\mathrm{kg})$ & Frango $(\mathrm{kg})$ & Suino $(\mathrm{kg})$ \\
\hline 1971 & 46,1 & 69,3 & 42,6 \\
1972 & 46,4 & 55,8 & 38,0 \\
1973 & 36,3 & 47,9 & 30,9 \\
1974 & 35,6 & 46,7 & 25,7 \\
1975 & 38,6 & 56,7 & 31,2 \\
1976 & 44,6 & 57,0 & 35,5 \\
1977 & 47,6 & 62,5 & 31,6 \\
1978 & 37,6 & 57,2 & 33,7 \\
1979 & 28,6 & 50,5 & 28,6 \\
\hline
\end{tabular}

Fonte: CASP - Informativo, no 6, ano 1, janeiro de 1981.

O crescimento das exportações brasileiras de frango foi vertiginoso. De um produtor secundário no mercado mundial, o Brasil começa a década de 1980 ocupando o segundo lugar entre os exportadores de frango. A exportação de frangos de corte evoluiu de 12,8 milhões de unidades em 1970 para cerca de 43,2 milhões em 1976 e cerca de 100,8 milhões de unidades (equivalente a 154 mil toneladas de carne) em 1980 (Gazeta Mercantil, 31 de dezembro de 1980, p. 16).

Segundo dados da ABEF (Associação Brasileira de Exportadores de Frangos, que em 1979 foi responsável por 96,7\% das exportações), U NEF (União Nacional de Exportadores de Frangos) e da UBA (União Brasileira de Avicultura), as exportações brasileiras de frangos começaram em 
1975, com 3,4 mil toneladas, de uma produção total de 484 mil toneladas. Em 1979 já foram exportadas 50,8 mil toneladas, de uma produção total de 772,8 mil toneladas. Portanto, apenas nesses quatro anos, enquanto a produção não chegou a duplicar, as exportações cresceram em quase 14 vezes. Somente o ano de 1979, em relação a 1978, teve um crescimento de 59,26\% no tocante ao peso, e de 72,96\% no tocante ao valor FDB. Em 1980 as exportações atingiram um total de 187.834.495kg, contra uma previsão da ABEF de 100 a 120 milhões de kg. 0 preço internacional manteve-se relativamente constante entre 995 e 923 dólares por tonelada, com exceção dos anos de 1979 e 1980, quando superou a marca dos mil dólares por tonelada (Dirigente Rural, set.-out. de 1979). 0 ano de 1980 foi o que teve o maior crescimento, até aqui, das exportações. Segundo estimativas da Cacex, esse incremento foi de $153 \%$ em relação a 1979 (Zero Hora, 22 de dezembro de 1980, p. 23).

Quadro 1.6

Evolução das exportações brasileiras de frangos

\begin{tabular}{lrr}
\hline Ano & Volume $/ \mathrm{kg}$ & Valor $/$ US $\$ / F O B$ \\
\hline 1975 & 3.469 .104 & $3.289 .780,00$ \\
1976 & 19.636 .012 & $19.564 .638,00$ \\
1977 & 32.828 .560 & $31.572 .462,00$ \\
1978 & 50.804 .868 & $46.871 .775,00$ \\
1979 & 81.095 .951 & $81.148 .255,00$ \\
$1980^{\mathrm{a}}$ & 160.000 .000 & $200.000 .000,00$ \\
\hline
\end{tabular}

a Previsão.

Fonte: Realidade Agroavícola, dezembro de 1980.

As empresas que iniciaram as exportações de frangos em 1975, por ordem de participação, foram a Sadia Concórdia (SC), a Perdigão S.A. (SC), Frigorífico Seara (SC), a Coopave (RS) e outros. Em 1980, do total de 187.834.459 kg exportados, participaram 43 empresas, encabeçadas por ordem de importância pela Sadia Concórdia S.A. (SC), Perdigão S.A. (SC), Frigorífico Seara S.A. (SC) e Coopave (Dados de Avicultura Industrial, (...), (852), p. 5 e Coopave, mar.-abr.-mai.junho de 1980, p. 44), o que demonstra o caráter mais de exportação da avicultura do Sul.

O fato de a avicultura do Sul ser fortemente de exportação talvez se deva a que, sendo lá recente a avicultura industrial, ela já teve início na fase exportadora, assim como também o próprio caráter da agricultura sulina de exportação, marcada por linhas de produção integradas. Além disso, a avicultura industrial no Sul é predominantemente de corte, justamente o ramo da avicultura que se orientou para exportação. Em ordem de volume exportado, os principais Estados nos últimos anos foram Santa Catarina, Rio Grande do Sul, São Paulo, Minas Gerais e Rio de Janeiro.

Frente à expansão do mercado e às dificuldades para exportação por empresas isoladamente, 
em 1976 foi criada a União Nacional de Exportadores de Frangos (UNEF) e a Associação Brasileira de Exportadores, a qual se filiara a ABEF. Através dessas associações os exportadores brasileiros pretendem conquistar mercados anteriormente ocupados pela produção dos países da Europa ocidental e oriental (Comércio Exterior, mar.abril de 1977, pp. 23-25). Em 1980, a UNEF pretendia colocar no mercado externo a cota de 9 mil toneladas mensais produzidas pelas dez empresas que fazem parte do consórcio, e que estavam comprometidas a exportar exclusivamente através da UNEF (Avicultura Industrial, agosto de 1980, p. 20).

Os principais países compradores são os países do Oriente Médio. Em 1980, por ordem de volume adquirido, o Kuwait, Iraque, Emirados da Arábia, Iêmen, Argentina, Omã, Líbano, Catar, Paraguai, Bahrain, Jordânia, EUA, Chile e Espanha formavam a quase-totalidade dos compradores. Nesse ano, a União Soviética ingressou no rol dos compradores de frangos brasileiros (ibid.). De qualquer forma, os países do Oriente Médio produtores de petróleo são responsáveis pela maior parte das aquisições, em estreita relação com as importações brasileiras de petróleo, tendo participação nas exportações inclusive a Petrobrás S.A., através da Interbrás, desde 1976.

Finalmente, não deixa de ser significativo o fato de que, sendo o Brasil importador de material genético, ele é hoje exportador de matrizes e pintinhos para produtores avícolas de outros países latino-americanos.

\subsection{CONCLUSÕES}

O impacto da expansão do complexo avícola atinge a estrutura de consumo da população (substituição da carne de boi por carne de frango e/ou aumento absoluto no consumo de proteínas de origem animal), reforça o próprio complexo agroindustrial e acelera a modernização de outros setores agrícolas (no caso da avicultura, a produção de milho) e a reorganização da produção de aves no meio rural.

A formação do setor avícola moderno no Brasil deve ser entendida como um processo de internacionalização de um setor agropecuário em função principalmente do seu mercado interno e dentro de um processo no qual as multinacionais, embora controlando aspectos centrais da tecnologia, são compelidas a uma interiorização crescente desta.

A interiorização da tecnologia avícola é possibilitada pelo desenvolvimento do parque industrial brasileiro, e particularmente do setor farmacêutico e de implementos e insumos agrícolas. Ainda assim, o ritmo de transferência depende em grande parte das pressões políticas e de estratégias das grandes empresas multinacionais e nacionais.

Dentro desse processo de interiorização da produção, se fortalecerá a tendência à formação de conglomerados agroindustriais avícolas formados por capital nacional e estrangeiro, os primeiros 
oferecendo seu controle de mercados nacionais e as vantagens que auferem no sistema creditício, e os últimos o controle de tecnologia, e eventualmente de mercados externos.

A exportação brasileira de frangos deve ser entendida como expressão de um novo tipo de exportação de produtos, diferente do modelo exportador tradicional. Enquanto o modelo tradicional de exportação se fundava particularmente na utilização extensiva de terra e força de trabalho, a exportação avícola atual tem como fundamento um moderno complexo agroindustrial crescentemente interiorizado, e como centro impulsionador central o próprio mercado interno. 


\section{CAPÍTULO 2}

\section{CAPITAIS, FRANGOS E CAMPONESES ${ }^{11}$}

\subsection{FORMAS DE PRODUÇÃO RURAL}

A avicultura moderna é filha das mais avançadas técnicas de engenharia genética aplicadas à produção industrial de carnes animais. Pelo alto grau de conversão de cereal em carne, é o frango o animal que melhor se adapta à produção maciça de carnes a menores preços. A partir do controle genético, confinamento e regulação alimentar, reduzem-se - quando não se eliminam - os determinantes naturais do ciclo de reprodução biológica do animal.

Quadro 2.1

Produção brasileira de matrizes para postura e ovos/consumo

\begin{tabular}{cccc}
\hline Ano & $\begin{array}{c}\text { Matrizes } \\
\text { Ovos brancos }\end{array}$ & $\begin{array}{c}\text { Matrizes } \\
\text { Ovos vermelhos }\end{array}$ & $\begin{array}{c}\text { Ovos } \\
\text { Milhões } / \text { dz. }\end{array}$ \\
\hline 1971 & 606.650 & 161.763 & 490 \\
1972 & 472.654 & 173.149 & 510 \\
1973 & 516.489 & 115.644 & 500 \\
1974 & 423.762 & 101.263 & 500 \\
1975 & 456.984 & 125.920 & 501 \\
1976 & 495.009 & 124.835 & 510 \\
1977 & 471.504 & 142.380 & 521 \\
1978 & 556.948 & 209.549 & 552 \\
1979 & 545.808 & 297.918 & $620^{\mathrm{a}}$ \\
1980 & $620.000^{\mathrm{b}}$ & $245.000^{\mathrm{b}}$ & $680^{\mathrm{b}}$ \\
\hline
\end{tabular}

a Estimativa.

b Previsão.

Fonte: Realidade Agroavicola, dezembro de 1980.

Para se ter uma noção mais concreta da apropriação das atividades produtivas pelo complexo agroindustrial, é indicativo o fato de que no preço final do frango, em 1976, o custo da mão-de-obra na granja de 12 mil frangos representava apenas $1,50 \%$ (3,85\%, se se inclui a previdência social).

\footnotetext{
${ }^{11}$ Este capítulo focalizará, em particular, os produtores de frangos de corte, e só em forma marginal os produtores de ovos. Isso, em parte, porque a produção de ovos tem tido um crescimento muito pequeno na década e, hoje, é em grande parte subsidiária da produção de frangos de corte.
} 


\begin{tabular}{lrr}
\hline Item & \multicolumn{1}{c}{ Cr\$ } & $\%$ \\
\hline 1. Custos fixos & & \\
1.1. Depreciação & $3.746,00$ & 2,81 \\
1.2. Administração & 600,00 & 0,45 \\
1.3. Despesas financeiras 15\% a.a. & $8.428,50$ & 6,32 \\
$\quad$ Subtotal & $12.774,50$ & \\
2. Custos variáveis & & \\
2.1. Pintos de um dia & $23.400,00$ & 17,56 \\
2.2. Mão-de-obra & $2.000,00$ & 1,50 \\
2.3. Rações & $88.311,85$ & 64,87 \\
2.4. Gás & $2.000,00$ & 1,50 \\
2.5. Energia elétrica & 600,00 & 0,45 \\
2.6. Maravalha & $1.200,00$ & 0,90 \\
2.7. Medicamentos e desinfetantes & 600,00 & 0,45 \\
2.8. Previdência social & $3.131,60$ & 2,35 \\
2.9. Perdas & $1.116,00$ & 0,83 \\
$\quad$ Subtotal & $120.479,45$ & \\
\hline Total geral & $133.254,95$ & 100,00 \\
\hline
\end{tabular}

Fonte: Cepa-SC, 1976.

Poder-se-ia, igualmente, somar o custo da mão-de-obra rural na produção da ração, para se ter uma idéia da participação do trabalho rural no preço final do frango. Um cálculo aproximado indica que, na produção da ração, $25 \%$ do custo pode ser imputado à mão-de-obra rural. Teríamos, nesse caso, que, no preço final do frango, a mão-de-obra rural participaria com $16 \%$ dos custos.

Esse processo tem uma dupla dinâmica. 0 capital industrial passa a se apropriar de atividades que anteriormente eram realizadas no interior da empresa rural, e, com base nessa apropriação, passa a impor aos produtores rurais os padrões e ritmos de transformação do processo produtivo. ${ }^{12}$ Os produtores rurais, ou seja, aqueles cuja atividade ainda depende em boa medida dos determinantes naturais no processo produtivo - em particular do uso extensivo da terra - ingressam, assim, num processo em que suas condições de reprodução estão superditadas e subordinadas à dinâmica do complexo avícola industrial.

A formação do moderno complexo avícola brasileiro é muito recente, tendo passado durante a década de 1970 por um processo de expansão, apoiado pelo crédito público subsidiado que permitiu o ingresso, no setor, dos mais variados tipos de produtores. Em grandes rasgos podem ser caracterizados dois grandes tipos de produtores rurais avícolas: as unidades produtivas familiares, de pequeno e médio porte, e as grandes empresas, fundadas no trabalho assalariado. ${ }^{13}$

Os produtores, pequenos e médios, se articulam com o complexo agrícola industrial através

\footnotetext{
${ }^{12} \mathrm{O}$ desenvolvimento dessa formulação pode ser encontrado em Goodman, Sorj e Wilkinson, 1982.

13 Trata-se aqui de uma caracterização simplificada, já que existem casos de granjas de médio porte trabalhadas por assalariados.
} 
de duas formas centrais: integração direta com a indústria de transformação e integração através do mercado. ${ }^{14} \mathrm{~A}$ integração direta com a empresa industrial pode dar-se através da participação de cooperativas que atuam no campo industrial (na produção de ração, pintos, e na transformação e comercialização do frango) ou com empresas privadas. Se bem que esses tipos possam ser encontrados nas diversas regiões do país, atualmente a primeira teria maior importância no Estado de São Paulo e, em particular, em Santa Catarina, e a segunda nos outros Estados.

$\mathrm{Na}$ primeira forma de articulação, foram praticamente eliminados os efeitos diretos do mercado nas relações entre a empresa integradora e o produtor rural. Na segunda forma, o mercado ainda organiza as relações entre os agentes. De qualquer modo, em ambos os casos trata-se de relações oligopólicas e oligopsônicas entre grandes empresas agroindustriais confrontadas com uma miríade de pequenos produtores.

\subsection{PRODUÇÃO AGRÍCOLA INTEGRADA: SANTA CATARINA}

\subsubsection{AS INTEGRADORAS}

Em 1964, a Sadia elaborou um plano com a Associação Rural de Concórdia e a prefeitura local (seu município de origem), segundo o qual o frigorífico entrava com cerca de 16 milhões de cruzeiros, sua organização e pessoal técnico, a prefeitura com 4 milhões de cruzeiros, maquinaria e áreas para experimentos, e a Associação Rural com pessoal técnico e fornecimento de medicamentos e outros produtos para o início de um programa de fomento à suinocultura, e, num segundo grau, outros produtos agropecuários, como a avicultura. A estratégia desse projeto era selecionar algumas propriedades rurais que servissem de modelo de modernização para a atração dos demais proprietários, numa metodologia semelhante à posta em prática pelos órgãos oficiais como a Acaresc. Conjuntamente, a Sadia desenvolveu uma intensa e permanente campanha publicitária, cujo principal veículo era a Rádio Rural de Concórdia, da própria Sadia. Ao lado disso, a empresa intensificou sua atuação no desenvolvimento genético e técnico, em geral, do rebanho suíno, e passou a aumentar suas exigências de padronização qualitativa, estabelecendo inclusive competições com prêmios para os produtores (Dirigente Rural, outubro de 1965, pp. 51-55).

Em 1977, por exemplo, enquanto a taxa nacional de desfrute era de 18\%, em Concórdia era de $84 \%$ e os desfrutes dos produtores integrados da Sadia eram de $145 \%$ (Avicultura \& Suinocultura Industrial, novembro de 1977, p. 63).

Em 1972, a partir do projeto anterior de fomento e da intensificação do esquema de assistência técnica, a Sadia formulou as relações contratuais entre o produtor rural e a empresa,

\footnotetext{
${ }^{14}$ A forma contratual não implica necessariamente a existência de contratos formalizados juridicamente.
} 
inicialmente com 100 unidades produtivas rurais, ampliando progressivamente. Essa nova forma de vinculação aprofundou a assistência técnica, fornecimento de insumos e aumento da produtividade física dessas unidades produtivas, ao passo que, para a empresa, resultou numa veloz acumulação de capital, a qual passou de uma capacidade de abate de 34.902 cabeças de suínos em 1945 para 389.141 em 1976, aumentando a produção industrial de dois milhões para mais de 222 milhões de $\mathrm{kg}$, no mesmo período.

Simultaneamente, com o desenvolvimento da produção de suínos que não teve maior expansão na última década, a Sadia formulou o programa de integração da produção de aves. Diversamente dos produtores de suínos, que já haviam se formado com um grau maior de independência em relação aos frigoríficos, a avicultura industrial, em Santa Catarina, surge integrada contratualmente, a partir do início dos anos 1960. A razão fundamental da facilidade que a Sadia e demais empresas integradoras tiveram para impor essa forma de relacionamento contratual foi o caráter da estrutura agrária, formada por pequenos produtores disponíveis e em condições sociais que não apresentavam outras opções. Em 1977, cerca de 95,5\% do total de abate de frangos em Santa Catarina eram provenientes da integração que já havia se desenvolvido de forma tal que abarcava desde a produção de pintos, rações e concentrados, fornecimentos de insumos em geral e assistência técnica intensiva, até o controle completo da comercialização e transformação industrial por parte da empresa integradora.

Em seu estágio mais avançado a empresa exige ainda a produção de milho e outros componentes da ração, com os quais a indústria integradora produz a ração que fornece aos produtores integrados. Já nesse período, na relação entre integrador/integrado não havia nenhuma estrutura de mercado, na medida em que o contrato determina a oferta, a demanda e o preço do produto (Cebrae/Ceag, 1978, p. 72).

Com a rápida expansão da indústria de processamento de aves, tanto o número de indústrias processadoras quanto a integração contratual tiveram um crescimento acelerado. Assim, enquanto em 1972 havia apenas uma indústria processadora, com 134 produtores integrados, com um abate anual de 3,3 milhões de cabeças e com uma média de 24.791 cabeças por integrado, já em 1976 eram nove as empresas processadoras, 953 integrados, sendo 106 para cada indústria. $\mathrm{O}$ abate anual era de 60 milhões de cabeças, com uma média de 62.959 para cada integrado. Das nove indústrias pesquisadas em 1977 pela Ceag/SC, oito produziam rações para frangos integrados e a maior parte dos pintos de um dia era fornecida pelas próprias indústrias. O restante estava a cargo de granjas especializadas na produção de pintos para os produtores ou para as indústrias integradoras que repassavam aos criadores de frangos. As principais razões apontadas para a aceleração da expansão de integração contratual de produção de suínos e aves em Santa Catarina estão ligadas ao tamanho 
da indústria de transformação que lidera o processo e a estrutura do mercado por ela condicionado. Entrevistas realizadas pela Ceag/SC em 1977 com as indústrias pioneiras na integração apontam no sentido de que o desenvolvimento da "(...) produção contratual surgiu como necessidade de descentralização de produção, à medida que a empresa atingia determinado tamanho. As dificuldades de dispor de investimentos para montar instalações necessárias à produção de frangos para abate tornam-se cada vez maiores, quanto maior é o número de aviários que seria preciso construir" (Cebrae/Ceag-SC, 1978, pp. 74-75). Contudo, além da estratégia estritamente administrativa, pensamos, como mostraremos mais adiante, que a integração contratual é resultado, fundamentalmente, das condições histórico-sociais e políticas onde está inserida e sob as quais são criadas as estratégias do capital.

De qualquer modo, se de um lado a integração contratual é resultado da concentração do capital industrial-comercial-financeiro que comanda o processo, de outro, resulta da acelerada centralização e conglomeração, passando o capital industrial a um grau progressivamente maior de oligopolização e conglomeração e atuando conjuntamente em diversos ramos e inclusive setores. ${ }^{15}$ De acordo com a pesquisa citada, dos dez frigoríficos existentes em Santa Catarina, em 1975, dois participavam com $60 \%$ do abate total e os quatro maiores atingiam a participação de $83 \%$. No período 1974-1975 havia sido duplicado o número de pequenos estabelecimentos responsáveis pelos restantes $16 \%$ do abate.

Nessa permanente expansão e centralização, as empresas integradoras pioneiras passaram a absorver progressivamente outras linhas de produção e setores, e, inclusive, a expandir sua área de ação. A Sadia (Grupo Fontana), por exemplo, implantou em 1970 um novo projeto, a Sadia Avícola, em Chapecó (SC), para produção e transformação de perus e frangos de corte. Em 1977 implantou a Sadia Agropastoril, em Faxinal dos Guedes (SC), para produção de 100 mil suínos com alto padrão tecnológico para exportação (Cebrae/Ceag, 1978, pp. 77-78). Conforme sua publicação Annual Report 79-80, e relatório, no final de 1979 o Grupo Sadia contava com as seguintes empresas: na avicultura, a Sadia Concórdia S.A. Ind. e Com. (SC), Sadia Avícola S.A. (SC), Frigobrás - Cia. Brasileira de Frigoríficos (PR) e Moinho Cepe S.A. (PR), que, em 1979, abateram mais de 60 milhões de unidades de aves; na suinocultura, Sadia Concórdia S.A. Ind. e Com. (SC) e Frigobrás (PR), abatendo em 1979 mais de 1.100 mil unidades; na comercialização, a Sadia

\footnotetext{
${ }^{15} \mathrm{O}$ comando da integração por parte da indústria processadora de carne se fundamenta na preexistência de produtores independentes e frigoríficos que já competem entre si por matéria-prima. A centralização do comando do processo das unidades industriais é para os frigoríficos a forma mais adequada no estágio atual, visto que os produtores rurais poderiam mudar de atividades diversificando sua estrutura produtiva nas conjunturas desfavoráveis enquanto a estrutura produtiva da indústria impede tal mudança. Por outro lado, o frigorífico sofre problemas de oferta insuficiente e irregular de matéria-prima. Quanto ao comando do processo pelas fábricas de rações através da integração da produção agropecuária, não existiriam experiências nacionais nem vantagens em relação aos frigoríficos.
} 
Comercial Ltda., responsável pela distribuição e comercialização dos produtos no mercado interno.

Além disso, o grupo estava coligado (ou controlava) em 1979 à Sadia Oeste S.A. Ind. e Com., INT - Plan Sociedade Civil Ltda., à Sadia Corretora de Seguros Ltda., Hotel Alvorada S.A., Sadia Joaçaba, Sadia Agropastoril, Hybrid Agropastoril, Agropastoril Paranaense, Agropastoril Paulista e à Sadia Proc. de Dados. Estava em fase de implantação a Sadia Agropastoril Goiás Ltda. A Holding Sadia Concórdia controla também a Transbrasil, ex-Sadia Transportes Aéreos, criada para transportar sua produção. (Sadia, Annual Report 79/80 e Sadia, Relatório 1979, janeiro e junho). Para a implantação do projeto em Goiás, a Sadia adquiriu uma área de 2.300ha. Esse projeto, formado pelas empresas Sadia Agropastoril Ltda. e Sadia Ind. e Com. Ltda., prevê para quando estiver em funcionamento, o abate anual de 10 milhões de perus e 72 milhões de frangos, resultando numa produção anual de 158 mil toneladas de carne. O projeto, num custo total de 4,8 bilhões de cruzeiros de 1980, compreende ainda uma fábrica de óleo de soja (600t/dia), uma fábrica de rações, 2.500 aviários e consumirá $40 \%$ da safra de soja de Goiás (A Granja, Suplemento Avícola, abril de 1980, p. 7).

O grupo maior concorrente da Sadia e que dela se aproxima em Santa Catarina é o Perdigão. Em 1978, o faturamento da "Holding" Sadia se dividia em 30\% de suínos, $20 \%$ de aves, 19\% de rações, $15 \%$ de óleo de soja e $16 \%$ de outros produtos. O Grupo Perdigão possui semelhança não apenas no tamanho, mas inclusive nas estruturas produtivas e estratégicas. Seu faturamento era composto por $28 \%$ de suínos, $27 \%$ de aves, $20 \%$ de rações e $25 \%$ de outros produtos. No exercício de julho de 1979 julho de 1980, o Grupo Sadia vendeu cerca de 30 bilhões de cruzeiros e o Grupo Perdigão cerca de 14 bilhões. Contudo, o Grupo Perdigão, se bem que menor, teve um crescimento mais acelerado nos últimos anos. Enquanto a Sadia aumentou o abate de suínos, por exemplo, em 48\% no período de 197679 , de 783 para 1,16 milhão de unidades, o aumento da Perdigão foi da ordem de 118\%. No abate de aves, a Sadia aumentou de 35,8 bilhões, em 1976, para 66 milhões (cerca de 84\%), e a Perdigão teve um crescimento no abate de $191 \%$.

A exemplo da Sadia, o Grupo Perdigão atua em diversos outros setores como serrarias, supermercados, distribuição de petróleo, moinhos, gráficas, hotéis, comunicações etc. Controla três estações comerciais de rádio em Santa Catarina, contra uma da Sadia, além de estar entrando no setor de televisão. Segundo seu diretor "se der lucro, melhor, mas nosso objetivo é sócio-políticoinstitucional". Porém pretende investir na produção de suínos, aves e rações, $80 \%$ de seu faturamento (Negócios em Exame, 2 de junho de 1980, p. 28). Até 1985, o grupo pretende duplicar seu tamanho, com a aplicação de 500 milhões de cruzeiros por ano de reinvestimentos dos lucros, financiamentos e captações de recursos no mercado acionário. O Grupo Sadia possui 17 empresas (95\% do faturamento provindos de atividades agroindustriais) e conta com a vantagem de maior 
mobilidade de recursos e domínio de mercado, através de uma rede de 60 mil postos de venda, contra 10 mil do Grupo Perdigão.

Em termos de controle de mercado, a Sadia detinha 12,6\% do mercado nacional de suínos em 1976 e passou a controlar 18\% em 1980, contra 3,5\% em 1976 e 9,3\% em 1980, da Perdigão. Em relação ao mercado nacional de aves, a Sadia evoluiu de 17,4\% para $18 \%$ e a Perdigão de 4,7\% para 8\% no mesmo período. Em 1980 a Sadia exportava 33\% e a Perdigão 50\% de suas produções (Negócios em Exame, 2 de julho, 1980, pp. 26-29).

Quanto à integração da produção avícola, tanto a Sadia quanto a Perdigão participam de todas as fases do ciclo produtivo, com exceção da produção estritamente de matéria-prima. Ambas produzem desde a ração consumida pelos integrados até a entrega dos produtos aos varejistas, inclusive, no caso da Perdigão, fabricando a própria embalagem e industrializando o couro dos suínos. Os dois grupos atuam com integração através de contratos, sendo que a Sadia em 1980 possuía 4 mil produtores integrados e a Perdigão, cerca de 1 mil.

Em 1980, o Grupo Perdigão adquiriu o Frigorífico Ouro, de Capinzal (SC) e a Comércio e Indústria Saulle Pagnoncelli, em Herval d'Oeste (sc). Conjuntamente com esta empresa (ativo de 335 milhões de cruzeiros), foram assumidas também unidades industriais para abate e processamento de suínos e aves, incubatórios, usina hidrelétrica e imóveis urbanos. Ao mesmo tempo, o grupo, em 1980, dobrou o faturamento em relação ao ano anterior (A Granja Avícola, Porto Alegre, junho de 1980, p. 18 e julho de 1980, p. 25).

A Perdigão ocupava a posição 221 na lista das 500 maiores empresas privadas no Brasil em 1980. A Sadia Comercial Ltda. (excluindo-se as demais do Grupo Fontana), a posição 92, a Sadia Concórdia S.A. Ind. e Com., a 148 e a Sadia Oeste S.A. a posição 425. Por outro lado, a Perdigão foi a segunda em crescimento da receita operacional, com 38,2\% em relação ao ano anterior.

\subsubsection{OS PRODUTORES AVÍCOLAS}

Pesquisa direta em 1978 constatou que, em Santa Catarina, onde a produção avícola é praticamente toda integrada, as exigências das empresas integradoras quanto à área mínima da unidade produtiva a ser integrada variava de 13 a 25ha, conforme a empresa. A importância atribuída à área mínima diz respeito, segundo a pesquisa, principalmente a necessidades técnicas para instalações, por influenciar a capacidade de financiamento do produtor, e "porque vai determinar a maior ou menor dependência do produtor com relação à atividade integrada, levando em consideração que, a partir da disponibilidade de terra para cultivo, o produtor tende a diversificar sua produção. 
Santa Catarina: Número e área dos estabelecimentos avícolas, 1978

\begin{tabular}{cc}
\hline Hectares & No de estabelecimentos \\
\hline Menos de 1 & 123 \\
1 a & 2 \\
2 a 5 & 63 \\
5 a 10 & 124 \\
10 a 20 & 114 \\
20 a 50 & 223 \\
50 a 100 & 413 \\
100 a 200 & 119 \\
200 a 500 & 29 \\
+ de 500 & 14 \\
\hline Total & 3 \\
\hline
\end{tabular}

Dos 1.236 estabelecimentos avícolas em Santa Catarina em 1978, nota-se, segundo o Quadro 2.3, concentração maior, em áreas de 20 a 50ha, sendo significativo, porém, o grande número em áreas bem menores, mesmo de menos de um hectare. Desses estabelecimentos, 809 utilizavam adubo, dos quais 311 adubos químicos, 174 adubo calcáreo, 1.146 utilizavam defensivo animal e 403 defensivo vegetal. Quanto ao tipo de força utilizada, 801 utilizavam força animal e 236 força mecânica, sendo a maior parte própria e a restante alugada. Cerca de 168 informantes possuíam um total de 203 tratores, ao passo que 735 possuíam 1.162 arados de tração animal e 46 possuíam 61 colheitadeiras e combinados, o que caracteriza o baixo grau de mecanização das produções complementares no próprio estabelecimento avícola (ibid.).

Quanto à mão-de-obra utilizada, é constituída basicamente pela mão-de-obra familiar na avicultura integrada horizontalmente, de forma contratual ou não. Essa mão-de-obra familiar é, inclusive, parte das exigências das empresas integradoras, se bem que isso nem sempre seja explicitado. Mesmo assim, em alguns casos e graus, é utilizada eventualmente mão-de-obra assalariada também na avicultura integrada contratualmente. Em média, os produtores de aves de Santa Catarina, integrados contratualmente e os sem contrato, ocupam dois a três trabalhadores por estabelecimentos. De 779 produtores entrevistados, 327 utilizavam eventualmente mão-de-obra externa e 162 utilizavam mão-de-obra permanente. A baixa utilização de mão-de-obra externa é explicada tanto pelo seu custo, que reduziria ainda mais o ingresso obtido na atividade, quanto pela predominância de pequenas e médias propriedades e pela utilização de modernas técnicas de produção, que aumentam a produtividade e diminuem o número de trabalhadores necessários (ibid., p. 110).

Quanto ao grau de instrução desses trabalhadores, no estrato de menores de dez anos, $60 \%$ 
não possuíam instrução, sendo que $26 \%$ das crianças até dez anos trabalhavam em média 4,5 horas/dia, sem remuneração. Das 372 pessoas economicamente ativas pesquisadas, com idade entre dez e 18 anos, 88\% possuíam o grau de instrução primária. Ainda com relação à utilização de mãode-obra, apenas $4 \%$ dos trabalhadores exerciam atividades fora da propriedade e somente $2 \%$ eram remunerados. Essa situação era tanto para os produtores integrados contratualmente quanto para os demais produtores de aves. Desse modo, a pesquisa conclui que "esses fatos mostram que a integração até então não tem contribuído, como era de esperar, para o desenvolvimento social do produtor rural" (ibid. ).

Quanto ao tempo de trabalho na propriedade, numa amostragem de 185 produtores integrados contratualmente e 12 sem contrato, 12,2\% trabalhavam de uma a oito horas por dia; 33,0\% de nove a 12 horas e 54,8\% de 13 a 16 horas diárias, em 1978 (ibid., Quadro 26).

Na produção de aves em Santa Catarina em 1978, 85\% dos custos eram constituídos por pintos, rações e concentrados, adquiridos das empresas integradoras. Tendo em vista que o valor das vendas é menor que os custos médios, a pesquisa estima "que cerca de $90 \%$ do valor da produção dessa atividade vão para o frigorífico na forma de diversos pagamentos. Somando as despesas financeiras decorrentes de empréstimos nos bancos, energia elétrica e gás, verifica-se que somente 5,5\% dos custos têm origem na propriedade do agricultor, ou seja: mão-de-obra e depreciação" (ibid., p. 169). A participação da mão-de-obra nos custos da produção é em média de 2,5\%, havendo casos de empresas integradoras em que essa participação baixa para 1,3\% e, com exceção de duas, mantém-se sempre abaixo de $2 \%$. Com exceção do item vacinas e medicamentos, é o componente dos custos com menor participação.

Com base nos cálculos dos custos da produção e dos preços recebidos, o estudo conclui que a "atividade avícola", segundo os dados da pesquisa, não tem apresentado lucratividade. Não há casos de saldo positivo, tomando-se a soma deles por frigoríficos. Mesmo não incluindo nos custos a mão-de-obra e a depreciação, o resultado geral não é favorável. Como o produtor não inclui nos seus cálculos os custos acima e mais energia elétrica, despesas financeiras e gás, sua suposição é que a atividade é lucrativa. Os produtores normalmente recebem do frigorífico um "excedente" dado pela diferença entre o valor das vendas do lote de frango e os custos com pintos, ração, previdência social, medicamentos e outras despesas que realiza junto ao frigorífico. Esse "excedente" é considerado pelo produtor como "lucro líquido" (ibid., pp. 169-70).

\subsubsection{RELAÇÃO INTEGRADOR/INTEGRADO}

Em nossas entrevistas com produtores rurais integrados na avicultura, na tentativa de examinar as disposições jurídicas contratuais, nenhum deles possuía contrato formalizado. Em geral 
os produtores se consideram em relações contratuais com a empresa integradora a partir de um "pacto" entre ambos. Os aspectos mais formais do contrato aparecem em especial em situações como a tentativa de transferência do produtor de uma empresa integradora a outra. Uma outra pesquisa constatou que na avicultura e suinocultura integradas, em Santa Catarina, as relações entre produtor rural integrado/empresa integradora se dão através do "estabelecimento de contratos escritos a partir do conjunto de normas previamente estabelecidas; contratos verbais que constituem a grande maioria, ou ainda a forma mais simples, representada pelo cadastro. Todas elas têm sua determinação no conjunto de exigências já mencionado" (Cebrae/Ceag-SC, pp. 141-42).

Dos produtores integrados pesquisados em 1979, em média $38 \%$ possuíam contrato escrito, $37 \%$ verbal e $23 \%$ estavam comprometidos pelo cadastro. A referida pesquisa concluiu que não existem diferenças substanciais entre essas diversas modalidades, devido ao condicionamento sócio-cultural da relação integrado/integrador. O cadastro não constitui uma forma legal de compromisso, mas uma relação de produção/venda através do registro da produção entregue, dos insumos adquiridos e do desempenho da unidade produtiva. A duração média dos contratos escritos era de até dois anos para $14 \%$ dos integrados por contrato escrito; $13 \%$ de três a seis anos; $10 \%$ mais de seis anos e $55 \%$ por tempo indeterminado, com fortes variações entre as empresas integradoras.

Nessa mesma época, $21 \%$ dos produtores integrados pesquisados e $44 \%$ das empresas integradoras afirmavam a existência de pagamentos de multas como condicionantes para a rescisão de contratos, enquanto $55 \%$ dos produtores e $12 \%$ das empresas afirmavam o contrário. Essa disparidade nas respostas demonstra a grande discrepância na interpretação dos contratos, acontecendo o mesmo em relação aos demais. Quanto à duração do contrato, 42\% dos produtores integrados afirmavam que as alterações contratuais eram promovidas em conjunto com a empresa integradora, $21 \%$ afirmavam que só esta podia modificar os contratos e $23 \%$ não sabiam quem poderia promover alterações contratuais. Quanto ao cumprimento do contrato, $82 \%$ dos produtores afirmavam que as empresas integradoras cumpriam os contratos e $15 \%$ o contrário, por não cumprir os preços, assistência técnica etc.

Em geral, por contrato de integração é designado o relacionamento e dependência direta entre produção agropecuária e empresa integradora, que pode ser formulada explicitamente através de contratos escritos, cadastros ou oralmente. O conteúdo desses "contratos" ou "pactos", formulados juridicamente ou não, diz respeito substancialmente à exclusividade na aquisição dos insumos por parte do produtor rural, ao padrão tecnológico e manejo a ser posto em prática sob orientação e assistência técnica da empresa e, fundamentalmente, à exclusividade e garantia da produção agropecuária por parte da empresa integradora. 
Quanto aos critérios de seleção dos produtores integrados, constatou-se que somente determinados produtores têm condições de preencher as exigências impostas pelos frigoríficos. Aliás, é o excesso de produtores dispostos a esse tipo de contrato que funciona como condicionador das relações produtor rural/integrador.

Conforme a referida pesquisa, os "produtores integrados não são produtores comuns, são escolhidos, em função de possuírem um número de hectares de terra acima da média dos produtores da região, de terem condições de obter crédito e de se situarem a uma distância relativamente próxima à indústria, diminuindo, assim, os custos de transporte. ${ }^{16}$ É fundamental que os produtores possuam certas características para que o projeto global da integração seja viabilizado, segundo a estratégia estabelecida pelo frigorífico" (Cebrae-Ceag, p.141).

Já o encarregado de relações públicas da Sadia Avícola (Chapecó-SC), em entrevista concedida em 3 de fevereiro de 1981, quanto à seleção de produtores integrados, inclui outras exigências, complementando as expostas acima. Conforme suas declarações, a primeira condição para ser integrado a essa empresa é que o produtor seja "minifundiário" e que a mão-de-obra seja familiar, porque "a Sadia não trabalha com proprietários absenteístas. (...) A família é que deve trabalhar no aviário, porque a Sadia não quer peão, porque o peão não tem o 'capricho' pela produção".

A segunda exigência é a produção do milho, que implica a necessidade de uma área mínima, embora não seja necessariamente grande, por se tratar de uma produção intensiva. A empresa impõe ainda que exista a menor distância possível em relação à indústria processadora; que o produtor tenha "tradição" no trabalho agrícola como garantia de que não abandonará a agricultura após possuir as instalações avícolas, comprometendo assim a produção de milho; e, por último, que o produtor possua reserva monetária para investimentos próprios. Satisfeitas essas exigências, a empresa encaminha e acompanha o projeto até sua conclusão e avaliza-o no Banco, passando a fornecer os insumos e comprometendo-se a adquirir a produção.

Embora todas as empresas integradoras exijam a produção de determinada quantidade de milho por parte do produtor integrado, o qual será vendido em sua quase-totalidade à empresa, esse milho tem pouca importância na aquisição de insumos por parte da empresa. Tanto a maior parte do milho quanto os, demais insumos são adquiridos por terceiros. A importância da produção de milho e outros produtos estaria em sua contribuição para a formação do excedente rural. "Infere-se daí que

\footnotetext{
${ }^{16}$ Essa diminuição da distância entre o integrado e a empresa integradora, que é um dos critérios para passar à condição de integrado contratualmente, além de diminuir o custo de transporte, "(...) oferece melhores condições de controle e fiscalização por parte do frigorífico, que pode evitar assim os desvios de produção para fora do esquema integrado" (Cebrae/Ceag-SC, op. cit., 1978, pp. 71-72).
} 
a produção de milho tem a função primordial de gerar excedentes na propriedade rural. Dado que a atividade integrada não apresenta resultados positivos, provavelmente estará havendo transferência do excedente de milho para esta última" (ibid., p. 266).

Evidentemente a produção industrial de aves é altamente excludente por sua própria seletividade estratégica, elegendo um determinado grupo de produtores e impondo suas exigências tecnológicas. Porém, para se explicar o violento processo de exclusão social da maior parte dos produtores tradicionais no Sul e, inclusive, seu cunho crescentemente mais tenso pela maior seletividade da fronteira agrícola, faz-se necessário tomar o conjunto das linhas de produção modernas. Isso porque a avicultura industrial é recente demais e, embora seja intrinsecamente excludente e seletiva, ainda não se consolidou ao ponto de a exclusão dos antigos produtores dessa linha de produção ser maior que a incorporação de novos produtores. Em outras palavras, a vinculação da moderna avicultura industrial ao processo de reprodução negativa do campesinato tradicional se dá em relação ao conjunto dos produtores tradicionais, e não apenas em relação aos antigos produtores de aves. Diversamente da produção de suínos, os antigos produtores de aves no Sul eram pouco representativos e não existe um processo de eliminação dos produtores tradicionais. Por outro lado, a pressão que a avicultura industrial faz no sentido da reprodução negativa do antigo campesinato, que extrapola a avicultura em si, pode se dar indiretamente, através, por exemplo, de sua influência no sentido de transformar a produção de milho, de produção a cargo do antigo campesinato, em uma linha de produção moderna e mecanizada, a cargo de outro estrato de produtores.

Seria interessante caracterizar um pouco esse processo de "seleção", tomando como exemplo os produtores de suínos, visto que, embora a avicultura não tenha entrado ainda nessa fase por ser recente e por ter sido criada numa situação em que não existia uma avicultura tradicional significativa para ser eliminada (com exceção, de pequena monta, no Rio Grande do Sul), a avicultura moderna, até agora, absorveu produtores mais do que os excluiu. $\mathrm{O}$ exemplo de suinocultura aqui é importante na medida em que nessa produção há uma seleção permanente dos produtores, impulsionada pela mudança do patamar técnico da produção acirrada pelas crises, reorganizando a produção e eliminando ou realocando parte dos produtores. Um projeto de "resseleção" dos produtores suínos para Santa Catarina foi elaborado explicitamente em 1976 pelo MA/Suplan DID IICA - Acaresc, para execução entre 1977-1986. Ao mesmo tempo em que pretende dar um impulso tanto quantitativo quanto qualitativo à suinocultura, o projeto redimensiona o tipo de produto e de produtor através da seleção de propriedades para sua aplicação (Min. da Agricultura/Suplan, 1976).

De qualquer modo, o que dá fundamento às condições sociais da integração é a formação histórica e a manutenção da existência de um bloco de produtores rurais em condições sociais de 
produção e de vida inferiores aos produtores efetiva ou potencialmente integrados. Para a manutenção desse bloco de produtores nessas condições, concorre uma série de elementos, onde se destacam primeiro, a própria dinâmica da produção agropecuária camponesa formada por estratos de produtores em condições diversas e onde o estrato em piores condições tende a se deteriorar; segundo, o grau de oferta de emprego de mão-de-obra nos setores capitalistas da economia; e, por fim, elementos "não-econômicos", tais como o desenvolvimento de uma determinada "tradição" e habilidade no desempenho de atividades próprias da agropecuária em bases familiares, o que pode ser "capitalizado" pela empresa integradora. Evidentemente, esses elementos "não-econômicos" não podem se chocar com as condições objetivas da organização da produção, mas isso é viabilizado pelas especificidades técnicas do processo de trabalho agrícola. Por exemplo, na pesquisa do Cebrae/Ceag-SC citada, na produção de suínos e aves em Santa Catarina, os frigoríficos que internalizaram parte da produção agropecuária através da produção direta não obtiveram vantagens econômicas, o que é atribuído em especial aos encargos sociais que a mão-de-obra assalariada acarreta, o que não acontece com a integração horizontal.

\subsection{PRODUTORES NÃO-INTEGRADOS: O CASO MINEIRO}

\subsubsection{AS ORIGENS}

A avicultura de granja empresarial em Minas, como nos demais Estados em que ela foi introduzida na década de 1950 e especialmente de 1960, já nasce com elevado nível tecnológico, se relacionado aos sistemas de criação tradicionais existentes. Isso se dá pela incorporação de melhoramentos genéticos, adoção de instalações mais apropriadas, alimentação racional e especializando-se em corte e postura processo e que ao mesmo tempo iria influenciar a estrutura incipiente da avicultura comercial mineira, segundo informação da Emater, foi o programa ETA (Escritório Técnico Agropecuário) dos "galpões de mil frangos", resultado de convênio entre os Estados Unidos e o Ministério da Agricultura no início dos anos 1960. Um dos resultados desse tipo de programa, segundo expressão de técnicos da Emater, foi a "pulverização" com que se iniciou a avicultura comercial em Minas, significando com isso a proliferação da produção nas mãos de pequenos produtores de reduzido plantel de aves.

O Quadro 2.4 dá uma idéia da evolução da distribuição da produção de carnes de aves no Brasil pelos principais Estados produtores no período 1972-1978. Enquanto São Paulo diminui sua participação percentual na produção nacional, esse Estado teve, no período, crescimento acima de $10 \%$ em taxas geométricas anuais. Enquanto Minas Gerais veio aumentando lentamente sua participação, Santa Catarina superou fortemente o Estado de Minas no período, passando de 4,9\% 
em 1972, para 22,9\% em 1978. O impulso decisivo por que passou a avicultura comercial em Santa Catarina teve início em 1971, segundo análise do BDMG, graças à entrada nesse ano de grandes frigoríficos no Estado, utilizando o sistema de integração horizontal da produção. Em 1978, 96\% da avicultura comercial de corte no Estado estava estruturada com base nesse sistema. Esse fator teria possibilitado a Santa Catarina taxas geométricas de crescimento superiores a $50 \%$ ao ano, no período 1972-1978.

Quadro 2.4

Brasil: Distribuição percentual da produção de carnes de aves por principais Estados produtores - 1972-78

\begin{tabular}{cccccccc}
\hline Ano & $\begin{array}{c}\text { São } \\
\text { Paulo }\end{array}$ & $\begin{array}{c}\text { Santa } \\
\text { Catarina }\end{array}$ & $\begin{array}{c}\text { Minas } \\
\text { Gerais }\end{array}$ & $\begin{array}{c}\text { Rio Grande } \\
\text { do Sul }\end{array}$ & Paraná & $\begin{array}{c}\text { Outros } \\
\text { Estados }\end{array}$ & Brasil \\
\hline 1972 & 50,3 & 4,9 & 11,8 & 5,7 & 2,9 & 24,4 & 100 \\
1973 & 48,2 & 6,2 & 12,3 & 5,0 & 3,5 & 24,8 & 100 \\
1974 & 47,5 & 8,8 & 13,0 & 5,2 & 3,2 & 22,3 & 100 \\
1975 & 46,1 & 15,5 & 12,7 & 7,6 & 3,9 & 14,2 & 100 \\
1976 & 49,8 & 16,0 & 12,0 & 9,0 & 4,2 & 9,0 & 100 \\
1977 & 45,3 & 18,9 & 12,0 & 10,9 & 3,9 & 8,9 & 100 \\
1978 & 38,1 & 22,9 & 13,3 & 12,3 & 3,9 & 9,5 & 100 \\
\hline
\end{tabular}

Fonte: Instituto de Economia Agrícola e Banco de Desenvolvimento do Estado de São Paulo.

O Quadro 2.5 mostra, a partir de 1978, brusca elevação da produção em Minas Gerais de carne de frangos, tendo elevado de 3,66 a disponibilidade interna de $\mathrm{kg}$ de frangos per capita em 1974, para 14,28 em 1980.

Quadro 2.5

Minas Gerais - Disponibilidade interna de frangos e ovos para a população total

\begin{tabular}{ccc}
\hline & \multicolumn{2}{c}{ Disponibilidade per capita } \\
\cline { 2 - 3 } Ano & Kg frango & Unid. ovos \\
\hline 1974 & 3,66 & 53,20 \\
1975 & 4,24 & 49,91 \\
1976 & 4,38 & 60,74 \\
1977 & 4,19 & 72,37 \\
1978 & 6,04 & 95,28 \\
1979 & 9,52 & 112,97 \\
1980 & 14,28 & 109,00 \\
\hline
\end{tabular}

Fonte: Emater/MG - Elaboração COADP/AV (Fernandes, 1981). 


\subsubsection{ESTRATIFICARÃO DOS PRODUTORES}

Chama-nos a atenção, inicialmente, a grande "pulverização" da produção por pequenos produtores avícolas que caracterizou a introdução da avicultura moderna em Minas. Não possuímos informações estatísticas que demonstrem esse fato para os anos anteriores a 1975. Os dados sobre classes de avicultores na avicultura de corte em Minas Gerais em 1975 oferecem, no entanto, uma boa ilustração desse aspecto para um total de 990 granjas de corte então detectadas por levantamento direto da Acar e AAMG Associação dos Avicultores de Minas Gerais. Mais adiante, oferecemos uma perspectiva da evolução dos diversos estratos de produtores no período 1975-1980, onde se observa uma nítida evolução da produção no sentido de se concentrar em mãos dos maiores produtores.

Em 1975, dos 990 produtores, segundo os dados da Acar/MG, enquanto 82,83\% possuíam plantéis inferiores a 10 mil aves e, destes, 52,32\% inferiores a 5 mil, os 17,17\% restantes com mais de 10 mil aves representavam mais de $52 \%$ da capacidade de alojamento (Quadro 2.6). Os produtores com capacidade de alojamento para menos de 10 mil aves, mas especialmente com menos de 5 mil, são classificados por todos os estudos técnicos como de pequeno porte, muito abaixo do mínimo técnico-econômico recomendável. São considerados marginais ou "franco-atiradores", e que, em situação de crise, reagem paralisando sua produção. Em 1975, por exemplo, na época do levantamento que deu origem ao Quadro 2.6, de 25\% das granjas paralisadas, o maior índice estava na classe inicial de produtores de até 2 mil aves, decrescendo o percentual à medida que crescia 0 total de plantel por avicultor, isto é, segundo os técnicos, à medida que a atividade assumia moldes empresariais pelo emprego de melhor tecnologia (alimentação, manejo, controle sanitário, boas linhagens etc.) (Cepa/MG, 1977, p. 76). Porém, como na atividade se verifica normalmente uma paralisação temporária de granjas em épocas de preços baixos, os índices verificados não podem ser tomados como paralisações definitivas. Tendo em vista, porém, situações de crises mais prolongadas, como parece ser a que atinge o setor mais recentemente a partir de meados de 1980, é de prever um maior índice de paralisações definitivas por parte de pequenos produtores ou aluguel de seus galpões a produtores maiores. 
Quadro 2.6

Minas Gerais: Avicultura de corte - dados técnicos de produção - 1975

\begin{tabular}{|c|c|c|c|c|c|c|c|}
\hline \multirow[b]{3}{*}{ Classe de avicultores } & \multirow{3}{*}{$\begin{array}{l}\text { \% de distri- } \\
\text { buição dos } \\
\text { avicultores }\end{array}$} & \multicolumn{3}{|c|}{ Capacidade de alojamento } & \multicolumn{3}{|c|}{ Plantel existente } \\
\hline & & \multirow{2}{*}{$\begin{array}{l}\text { \% de distribui- } \\
\text { ção do plantel }\end{array}$} & \multirow{2}{*}{$\begin{array}{l}\text { \% de ociosidade } \\
\text { das granjas }\end{array}$} & \multirow{2}{*}{$\begin{array}{c}\text { Média capac. } \\
\text { aloj. por } \\
\text { avic. (no) }\end{array}$} & \multirow{2}{*}{$\begin{array}{l}\text { Média aves } \\
\text { por avicultor }\end{array}$} & \multicolumn{2}{|c|}{$\begin{array}{l}\text { Volume médio vendas } \\
\text { por avicultor }\end{array}$} \\
\hline & & & & & & Mensal & Anual \\
\hline Até 2.000 aves & 25,55 & 6,25 & 39,73 & 1.761 & 1.061 & 682 & 8.184 \\
\hline De 2.001 a 4.000 aves & 26,77 & 12,79 & 33,00 & 3.440 & 2.305 & 1.328 & 15.936 \\
\hline De 4.001 a 10.000 aves & 30,51 & 28,70 & 31,59 & 6.774 & 4.634 & 2.628 & 31.536 \\
\hline Acima de 10.000 aves & 17,17 & 52,26 & 30,78 & 21.917 & 15.172 & 8.602 & 103.224 \\
\hline Total/Média estadual & 100,00 & 100,00 & 31,85 & 7.201 & 4.907 & 2.809 & 33.708 \\
\hline
\end{tabular}

Fonte: Acar/MG e AAMG, em "Aspectos econômicos da avicultura de corte em Minas Gerais".

Já em 1979, de unia amostra de 1.652 produtores no Estado, representativa respectivamente de $94 \%$ dos avicultores de corte e $71 \%$ dos de postura, verificou-se que cerca de $75 \%$ dos de corte e $54 \%$ dos de postura possuíam uni plantel inferior a 10 mil aves. Por outro lado, somente $20 \%$ e $6 \%$, respectivamente, correspondiam à parcela de participação desse estrato de produtores de menos de 10 mil aves na produção total de frangos e ovos de Minas. A situação estadual mostrava então que $80 \%$ dos frangos produzidos estavam em mãos de $25 \%$ de produtores de corte e $94 \%$ dos ovos produzidos saíam de $46 \%$ dos produtores de postura, ambos com plantéis de mais de 10 mil aves (Fernandes, 1980, p. 11). Como se viu, em 1975 cerca de 17\% dos produtores de corte com capacidade de alojamento para mais de 10 mil aves controlavam apenas $52 \%$ dos frangos produzidos no Estado.

A transição recente da concentração da produção em pequenos avicultores para "médios e grandes" pode ser avaliada pelo fato de que a capacidade média de alojamento por avicultor passou de 5 mil em 1975 para 12.960 em 1979 e 13.360 em 1980 (Fernandes, 1980, p. 6). Por outro lado, segundo dados de 1977, para três regiões de Minas que, em 1978, detinham mais de 83\% dos avicultores mineiros, constata-se que mais da metade dos avicultores estavam na atividade há menos de cinco anos. Isso também acontecia na região Centro, onde $58 \%$ dos avicultores têm menos de cinco anos na atividade, e onde a avicultura de corte é mais antiga, com mais de 15 anos de existência. Combinados esses dados com a informação de que em 1974 os avicultores de corte em Minas eram 1.226 e 513 os de postura, e que por outro lado eles haviam decrescido para $931 \mathrm{e}$ 358, respectivamente, em 1977, pode-se ter uma idéia da instabilidade dos produtores avícolas, onde é grande a entrada de nossos produtores, mas também é alta a saída de outros.

A partir de 1978, porém, cresce rapidamente o número de produtores de corte - e especialmente a capacidade de alojamento - , passando os primeiros de 1.209 em 1978 para 2.094 em 1980, e a capacidade de alojamento de 11.935 .700 para 27.981 .490 cabeças no mesmo período 
(Fernandes, 1980, p. 6). A entrada de novos produtores de maior porte no ramo foi facilitada a partir de 1975 pela possibilidade de se obter crédito oficial junto ao Banco do Brasil, que sempre preferia, segundo técnico da Emater, financiar, entre os produtores de aves, os maiores e, entre os diversos produtos agrícolas, especialmente aves, pois isso significava operações de crédito maiores num único projeto em relação à dispersão de projetos pequenos em outros produtos como milho etc. Ainda segundo o coordenador de avicultura da Emater/MG, a centralização mais recente do setor avícola no Estado se dá a partir de 1978, entendendo como tal a eliminação de pequenos produtores em favor de outros de médio e grande porte, tendo em vista especialmente as dificuldades de capitalização dos pequenos produtores, como se verá adiante.

Apesar de não possuirmos dados sobre a evolução da estratificação dos produtores para avicultores de corte, o Quadro 2.7, relativo à evolução dos estratos de avicultores de postura (produção de ovos comerciais), oferece uma boa idéia sobre o ritmo de concentração do setor. Enquanto os avicultores com plantéis de mais de 30 mil cabeças representavam apenas 4,32\% em 1975, eles eram 32\% em 1980, com uma variação, no período, de mais 640, 74, responsáveis por $76 \%$ do plantel mineiro. No geral, a tendência é a diminuição do número de avicultores com pequenos plantéis e o aumento e concentração da produção em maiores produtores.

Nesse sentido, deve-se levar em conta especialmente o crescente ritmo de integração vertical na avicultura mineira, tanto na de corte como na de postura, nos anos recentes. Tendo em geral iniciado como produtores de corte, essas empresas integradoras foram se expandindo por outros ramos da avicultura em direção à integração vertical, como a Rezende Empreendimentos Alimentícios e a Granja Igarapé Ltda., as duas maiores em Minas, estando a Rezende entre as maiores do país. Com exceção da genética, a Rezende controla todas as fases da avicultura, tendo seu faturamento evoluído de 127 milhões em 1977 para 2.957 bilhões em 1980. Com exceção das matrizes (que compra da Rezende), a Igarapé é independente nas demais fases, possuindo hoje granjas de matrizes e frangos de corte, incubatório, abatedouro e fábrica de rações e já começa a colocar seus produtos no exterior (Exame, 1980; Avicultura Industrial, n.9 837).

\subsubsection{INSTABILIDADE DOS PRODUTORES}

A tendência à diminuição de produtores de pequenos plantéis e o aumento de produtores maiores é o resultado tanto do sucesso e capitalização de alguns empreendimentos como da real eliminação dos que não conseguem fazer frente aos aspectos técnicos e econômicos da produção, de modo a suportar situações de oscilações nos fatores de produção e comercialização. Assim, e independentemente de outros fatores, estudos acurados para a região Sul de Minas, responsável por $60 \%$ da produção total de ovos no Estado, demonstram que, na região, as granjas de postura, para 
uni mínimo de estabilidade, deviam ter um plantel acima de 10.303 aves. (Barrios, 1979, p. 46). Em 1975, no entanto, para a região, de um total de 417 produtores, apenas 106 possuíam plantéis superiores a 10 mil aves, estando a maior concentração (157 avicultores) situada em produtores de 1 mil a 5 mil aves, com 34 produtores com plantéis inferiores a mil aves (ibid., 4). Quanto à avicultura de corte, embora não se disponha de estudos tão precisos, os estudiosos do assunto são unânimes em afirmar que o tamanho econômico dessa exploração se situa em plantéis de 12 mil aves no mínimo (Fernandes, 1980, p. 13). Como se viu antes, no entanto, em 1979, 75\% dos avicultores de corte ainda possuíam plantéis inferiores a 10 mil aves.

\section{Quadro 2.7}

Minas Gerais - \% de distribuição dos avicultores de postura por estratos

- sua variação no período de 1975-1980

\begin{tabular}{|c|c|c|c|c|c|c|}
\hline \multirow[b]{2}{*}{ Classe de avicultores } & \multicolumn{2}{|c|}{1975} & \multicolumn{2}{|c|}{1980} & \multicolumn{2}{|c|}{ Variação no período } \\
\hline & $\begin{array}{l}\text { \% de distri- } \\
\text { buiçāo de } \\
\text { avicultores }\end{array}$ & $\begin{array}{l}\% \text { de distribui. } \\
\text { ção do plantel }\end{array}$ & $\begin{array}{l}\text { \% de distri- } \\
\text { buiçāo de } \\
\text { avicultores }\end{array}$ & $\begin{array}{l}\text { \% de distribui- } \\
\text { ção do plantel }\end{array}$ & $\begin{array}{c}\text { Distribuição dos } \\
\text { avicultores }\end{array}$ & $\begin{array}{c}\text { Distribuição } \\
\text { do plantel }\end{array}$ \\
\hline Até 5.000 aves & 45,80 & 12,71 & 32,0 & 2,0 & $-30,13$ & $-80,26$ \\
\hline 5.000 a 10.000 aves & 28,78 & 20,90 & 22,0 & 4,0 & $-23,56$ & $-80,86$ \\
\hline 10.000 a 30.000 aves & 21,10 & 33,35 & 14,0 & 18,0 & $-33,65$ & $-46,03$ \\
\hline Acima de 30.000 aves & 4,32 & 33,04 & 32,0 & 76,0 & $+640,74$ & $+130,02$ \\
\hline Total & 100,00 & 100,00 & 100,00 & 100,00 & - & - \\
\hline
\end{tabular}

Fontes: Realidade Avicola, ACAR, 1975. Avicultura Mineira: Uma Exploração em Debate, Emater, 1980, claborado pcla Coadp$\mathrm{AV} /$ Emater-MG.

O estudo sobre granjas de postura no Sul de Minas referido acima distribui os produtores em estratos: estrato A, de 1 a 8 mil aves; estrato B, de 8.001 a 20 mil aves; estrato C, acima de 20 mil aves. Suas conclusões são extremamente elucidativas com relação aos problemas que afetam esses estratos. Nota-se que os custos médios de produção diminuem à medida que aumenta o tamanho dos empreendimentos. O estrato A, de pequenas granjas, apresentava no primeiro trimestre de 1978 um custo de produção para a caixa de ovos de 271 cruzeiros, valor este acima do preço médio do mercado no período da pesquisa, isto é, 253 cruzeiros. Os estratos maiores, B e C, porém, tinham custos de produção inferiores ao preço do mercado, 233 e 224 cruzeiros respectivamente. A taxa de rentabilidade relaciona o lucro com o capital fixo total da empresa, representado por benfeitorias, máquinas e implementos. As pequenas empresas apresentaram uma taxa de rentabilidade de 3,1\% ao mês, ao passo que as médias atingiram 4,5\% e as grandes 5,5\%. Segundo o autor, "compreendese o comportamento dessas taxas, uma vez que as grandes empresas adquirem os insumos em maior quantidade e, à medida que o tamanho da granja cresce, também cresce o número de empresas que misturam a ração na propriedade, fatos que permitem a obtenção de insumos com menores preços, 
contribuindo assim na redução dos custos de produção" (Barrios, 1979, pp. 45-47).

Outros dados do estudo são ainda esclarecedores. A conversão alimentar, por exemplo, que indica a quantidade de ração gasta para produzir uma dúzia de ovos, apresenta as pequenas granjas com menor eficiência. Enquanto o índice preconizado são $2 \mathrm{~kg}$ para produção de uma dúzia, as pequenas gastam $2,17 \mathrm{~kg}$ e as médias e grandes $1,92 \mathrm{~kg}$ respectivamente. Considerando-se que o item ração representou mais de $80 \%$ dos custos variáveis, portanto numa participação elevada nos custos totais, esse índice de conversão alimentar destaca-se como um dos fatores importantes para explicar a diminuição dos custos de produção dos maiores produtores, assim como sua elevação no caso dos pequenos. Do mesmo modo, enquanto a quantidade de ovos por ave/ano no estrato A, de pequenas granjas, é de 222, nos estratos B e C é de 240. A compra dos componentes da ração em separado e sua mistura na granja diminui em geral os custos de produção em relação à compra da ração já acabada. A pesquisa indicou que apenas $10 \%$ das granjas pequenas misturavam ração na granja o ano todo, enquanto esse índice se elevava para $42 \%$ nas granjas médias e para $92 \%$ nas grandes ${ }^{17}$ (Barrios, 1979, pp. 30-39).

Tentando estabelecer uma relação entre o volume de produção e as oscilações dos preços de mercado, a referida pesquisa pôde verificar o efeito de tais oscilações sobre os três estratos de produtores. Foram utilizadas quatro combinações baseadas nas variações de preços ocorridas entre 1971 e 1977. Nas duas primeiras, o preço do concentrado foi deixado constante e o preço do ovo foi abaixado em $15 \%$ e $30 \%$. Nas outras duas o preço do ovo não foi alterado mas o concentrado foi aumentado em $5 \%$ e $10 \%$. O resultado foi que as pequenas e médias empresas (estratos A e B) não suportam nenhuma variação em que haja queda do preço do ovo e alta do concentrado. Eles alertam: "Se qualquer das combinações de redução do preço do ovo e elevação do preço do concentrado ocorrer simultaneamente, pequenas e médias granjas não sobreviverão e deixarão o mercado", enquanto as empresas da categoria c resistem satisfatoriamente a algumas combinações mais adversas. Como recomendações, os autores aconselham "uma atenção especial aos avicultores de postura com plantéis menores que 10.303 aves, no sentido de capitalizar suas empresas para ultrapassarem esse nível de alojamento". (...) "Os técnicos deverão visitar essas granjas e estudar, juntamente com os proprietários e os bancos, a possibilidade de ampliá-las. Algumas certamente não apresentam condições de crescimento. Mas seus proprietários deverão ser alertados para os riscos que correm se continuarem no ramo" (Avicultura Industrial, novembro de 1980).

\footnotetext{
${ }^{17}$ No caso de um pequeno produtor por nós visitado, por exemplo, ele não mantinha contabilidade, trabalhava em vários galpões simultaneamente e mantinha frangos caipiras (o que aumenta as possibilidades de contaminação e transmissão de doenças), não possuía caminhão nem misturador (o que aumenta seus custos de ração) e utilizava todas as drogas que o vendedor desses produtos indicava. Esse produtor, com a crise, abandonou a produção de aves.
} 
Ainda que não existam dados tão acurados para os custos da produção comercial de frangos de corte como os apresentados para a avicultura de postura, a dinâmica do setor e das classes de produtores que o compõem não é diferente. Na composição dos custos de produção de $1 \mathrm{~kg}$ de frango, o item ração entra com cerca de $70 \%$, sendo, portanto, o seu determinante fundamental. Como decorrência da majoração dos preços dos insumos da ração, milho (com participação de cerca de 70\%) e concentrados comerciais (30\%), em especial a partir de meados de 1980, tem-se uma redução pronunciada das margens de lucro dos produtores. Tal fato é confirmado pela relação frango/ração que a partir de maio de 1980 atingiu o nível mais baixo dos últimos anos. A relação frango/ração resulta da divisão do preço recebido pelo produto (frango vivo em $\mathrm{Cr} \$ / \mathrm{kg}$ ) pelo preço que o produtor paga pela ração para corte (em $\mathrm{Cr} \$ / \mathrm{kg}$ ) no mercado atacadista. Conforme dados apresentados por técnicos da Emater/MG, se em janeiro de 1978 o produtor, com o preço de $1 \mathrm{~kg}$ de frango, podia comprar 4,24kg de ração, em dezembro de 1980, $1 \mathrm{~kg}$ de frango comprava apenas 2,72kg de ração (Fernandes, 1981, p. 2). A Figura 1, por outro lado, dá uma idéia da evolução dos preços da ração, milho, frangos de 1971 a 1979, onde aparece clara, a partir de 1974, a dissociação dos preços dos produtos com relação à ração, aumentando desproporcionalmente esta última com relação aos preços de frangos.

O impacto dos dados acima é evidentemente diferenciado segundo as diferentes classes de produtores, apesar de abranger todo o ramo da avicultura como tal. Diferentemente dos maiores produtores, os pequenos não possuem infra-estrutura para estoque de ração na granja, nem dispõem de aparelhamento para mistura na granja dos componentes da ração. Em vista disso, devem comprar ração pronta muitas vezes através de intermediários/atravessadores que, ao mesmo tempo em que fornecem ração ao pequeno produtor, o atrelam à venda exclusiva do produto frango/ovo. $\mathrm{O}$ impacto do uso da ração pronta em vez da sua mistura na granja é significativo para o encarecimento dos custos de produção. Dados de 1978 para a Zona da Mata indicavam que o uso de ração pronta foi o responsável pela produção de um frango $17,87 \%$ mais caro do que aquele produzido com ração misturada na granja (Ferreira, 1979, p. 13). Informação obtida de veterinário em Pará de Minas, em março de 1981, indicava que a ração misturada na granja era 2 cruzeiros mais barata por $\mathrm{kg}$ do que a comprada pronta. Pode-se perceber o impacto desse fator, quando dados informais junto a fábricas de ração e distribuidores internos permitem concluir que o consumo da ração pronta, ainda hoje em Minas, apresenta 40 a $45 \%$ do total de ração destinada a produção avícola (Fernandes, 1980, p. 17). 


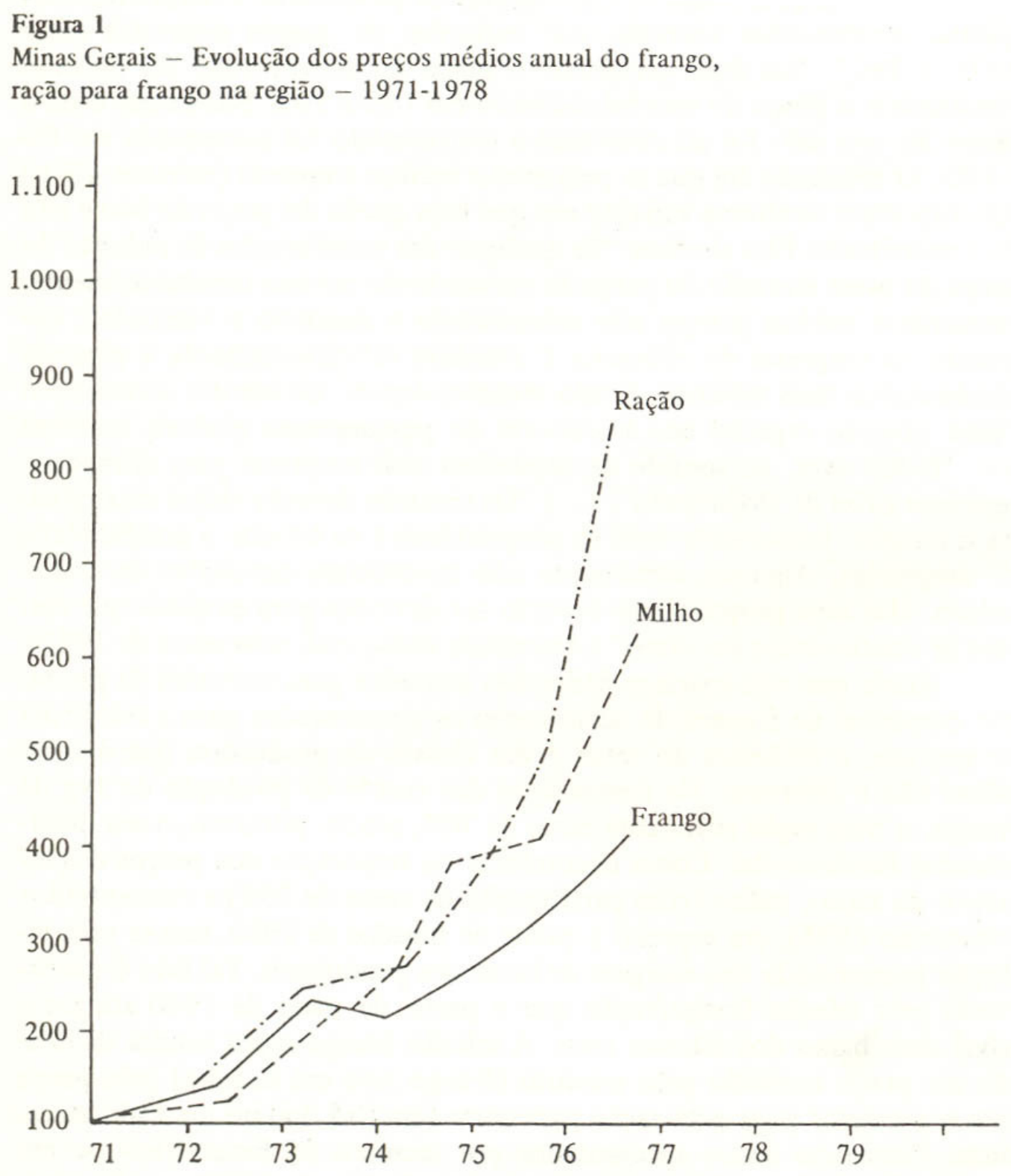

Fonte: Evolução dos preços Agropecuários de Minas Gerais - CPLAN Emater/MG Teixeira da Silva, J. - 1979.

A alta vertiginosa nos custos de produção, que tem por base o custo da ração e, neste, o custo do milho (o milho passou de cerca de 5 cruzeiros o $\mathrm{kg}$ em início de 1980 para 15 cruzeiros o $\mathrm{kg}$ em março de 1981, elevando o preço do $\mathrm{kg}$ da ração de 6,5 para 15 cruzeiros no mesmo período), conjugada ao nível de superprodução em Minas em 1980, resultante do aumento quantitativo entre 1977 e 1980 da capacidade produtiva instalada no período (cerca de 8 milhões de cabeças em 1977 para 28 milhões em 1980, em avicultura de corte), vem resultando, desde meados de 1980, numa crise prolongada da produção avícola em Minas, afetando diferencialmente as diversas categorias de produtores. Com relação somente ao setor de pintos de corte, por exemplo, em março de 1981 a produção mineira foi $42 \%$ menor do que a capacidade de produção das 
matrizes instaladas no mesmo período. Levantamento realizado pela Emater/MG no final de 1980 indicava que, entre outubro e novembro desse ano, 400 avicultores estavam paralisados, representando perto de 3 milhões da capacidade instalada de aves de corte, ou 10\% dessa capacidade, e que cerca de 65 mil poedeiras no Estado tinham sido eliminadas sem reposição de plantel. O total de avicultores paralisados representava cerca de $25 \%$ dos avicultores mineiros, e a média de aves por avicultor era de 7.600 cabeças. (Entrevista Emater/MG, junho de 1981.)

Segundo a própria Emater/MG, isso demonstra o fato -já conhecido - de que são os pequenos produtores, "aqueles considerados marginais ou franco-atiradores, que reagem paralisando suas criações", aos primeiros problemas de crise no setor. Em situações como essas as paralisações tanto podem significar para o avicultor a espera de superação da crise para reiniciar a produção, como alugar suas instalações para avicultores maiores ou simplesmente sair do ramo. Há casos, como alguns observados no município de Pará de Minas, em que o pequeno avicultor, tendo sublocado suas instalações a outros produtores, estes também são atingidos pela crise e desistem do negócio, ficando o primeiro definitivamente eliminado. As crises do setor, desse modo, redundam normalmente numa seleção de avicultores, tanto maior quanto mais prolongada for, readaptando as diversas camadas de produtores às novas condições de produção e comercialização. Essa parece ser a fase atual.

Na verdade, a situação crítica que se iniciou em 1980 prosseguiu em 1981 e as paralisações totais ou parciais começaram a atingir as empresas de incubação e grandes e médios avicultores. ${ }^{18}$ Pesquisa realizada pela Associação de Avicultores de Minas Gerais nos primeiros meses do ano identificou entre 169 produtores pesquisados:

a) uma ociosidade de $27,13 \%$ da capacidade produtiva de 102 produtores de frango de corte com uma média de plantéis de 45 mil aves cada um, sendo 9,84\% de plantéis paralisados e 17,28\% de plantéis reduzidos;

b) uma ociosidade de $20,19 \%$ da capacidade produtiva de 60 produtores de galinha de postura com uma média de 42 mil poedeiras cada um, sendo 2,81\% de plantéis paralisados e $17,38 \%$ de plantéis reduzidos;

c) uma ociosidade de $24,33 \%$ da capacidade produtiva de sete empresas de incubação com uma média de 92 mil matrizes cada uma, significando eliminação de 24,33\% de matrizes sem reposição (Fernandes, 1980, p. 6).

\footnotetext{
${ }^{18}$ A crise da avicultura brasileira que está se estendendo desde fins de 1980 até o momento atual (agosto de 1981), é produto de uma expansão acelerada da capacidade instalada durante os últimos anos (graças ao crédito rural subsidiado) e da recessão econômica que está levando a uma diminuição do consumo de carne em geral, e de aves em particular. Isso porque a carne bovina, produzida em forma extensiva, tem maior capacidade de resistir à baixa real de preços do que a carne produzida industrialmente, onde os custos dos insumos industriais são mais inelásticos.
} 
Mais recentemente, tem-se notícia de que a Granja Rezende, por exemplo, teria dispensado cerca de mil de seus empregados. A Igarapé, por outro lado, despediu 250 dos seus 700 empregados do setor de construção, conforme informação de seu presidente, e sua planta incubadora para 1,5 milhão de pintos mensais está hoje produzindo 800 mil, ao mesmo tempo em que começa a colocar seus produtos no exterior. ${ }^{19}$

A esta altura, somos levados a uma qualificação do argumento técnico com base em teorias de economia de escala que procura estabelecer um tamanho mínimo de plantel da empresa avícola que a faça operar com lucro e tenha estabilidade. $\mathrm{O}$ argumento certamente é válido desde que se tenham em conta as condições de produção em que estão inseridos esses empreendimentos. Situações de crises maiores acabam atingindo todos, de modo diferenciado, é evidente, e pressionam para uma readaptação da estrutura produtiva.

No caso de Minas, onde praticamente a avicultura não está estruturada em bases de integração horizontal, mas onde os produtores, especialmente os de pequeno porte, estão sob o controle do capital comercial de intermediários e atravessadores (como se verá na seção seguinte), a instabilidade destes produtores é maior, assim como também a dos próprios atravessadores. Pareceria que essa estrutura é bastante débil para fazer frente a situações adversas. Assim, por exemplo, existem indicações preliminares de que para fazer frente à situação atual, a readaptação da estrutura de produção em Minas possa caminhar para as duas vertentes ao mesmo tempo, tanto o fortalecimento da integração vertical como a implantação da horizontal, ou a integração por contrato.

Têm surgido notícias de que grandes atravessadores, por exemplo, que operavam com frota de veículos para compra direta de aves dos produtores e venda aos frigoríficos, estejam adquirindo abatedouros próprios para integrar sua atividade de modo a fazer frente à situação. (Entrevista com veterinário, junho de 1981.) Boa parte desses atravessadores já operava também com granjas próprias. Essa operação é em parte viável pela existência de um grande número de pequenos abatedouros em condições precárias, e que enfrentam problemas específicos na situação atual.

Por outro lado, existem também indicações de que a integração horizontal possa ser uma saída para a crise como estratégia de grandes empresas. Essa via é atualmente incentivada pela Emater/MG como solução para os pequenos produtores, juntamente com o associativismo, vindo mesmo atuando na programação junto a empresas que queiram adotar integração horizontal como já o fez com a Rio Branco, única empresa em Minas que adotou integração horizontal de 80

\footnotetext{
${ }^{19}$ As empresas integradoras teriam, aparentemente, menores prejuízos em época de crise do que as empresas com integração vertical. As primeiras poderiam repassar parte do custo da crise aos produtores enquanto as últimas estariam mantendo ocioso um montante muito alto de capital fixo.
} 
avicultores em 1980. Nesse sentido, entre suas estratégias para 1981-82 está a de "ampliar e implantar granjas, quando vinculadas a garantias contratuais de fornecimento de insumos e colocação da produção, e que tenham ou passem a ter toda a infraestrutura necessária à produção. Em especial prioridade situam-se aquelas granjas abaixo das economias de escala, que disponham das condições de endividamento que tal ampliação requer". O associativismo coloca-se como estratégia maior da Emater, "entendida como ação de impacto e de concentração de esforços", com o objetivo de diminuir os custos de produção e evitar a intermediação: "Desenvolver o espírito associativista entre os produtores, industriais de abate, de produção de pintos de um dia e de rações, acompanhar, orientar e participar junto às suas formas associativistas, promovendo sua aproximação e interação, buscando a redução dos custos e a diminuição da intermediação na comercialização, a partir de grupos organizados" (Fernandes, 1981, pp. 12 e 13).

As hipóteses levantadas acima serão confirmadas no futuro; é claro, porém, que não deixa de ser interessante, no momento atual, a procura de alternativas para readaptar uma estrutura produtiva que vem se revelando extremamente débil em momentos de oscilações do mercado quando se distanciam custos de produção e preços do produto. Com relação aos demais Estados avícolas brasileiros, segundo dados da Apinco de 1981, Minas seria o Estado onde a crise atual estaria tendo maiores impactos. Se, além da solidificação da integração vertical, a tendência da integração horizontal conseguir ir adiante, teríamos então, como resultado da crise, uma readaptação em que uma camada de pequenos "camponeses" avícolas seria marginalizada da produção, seguindo tendência de anos anteriores, enquanto uma outra seria constituída por camponeses que, superando a crise, seriam integrados diretamente ao capital industrial através da integração horizontal, ou subsistiriam em cooperativas de produtores, em que pese ao reduzido sucesso até o presente, quanto à difusão do associativismo.

Na possibilidade dessa readaptação das condições de produção avícola em Minas, não se pode menosprezar a ação de órgãos públicos atuando no setor avícola, tanto do lado da integração vertical como da horizontal. Do lado da integração vertical atuam prioritariamente os agentes financeiros do Estado, no caso de Minas, o Banco de Desenvolvimento (BDMG) com recursos do Banco Central. O Programa de Desenvolvimento da Avicultura de Corte do BDMG para 1980-83 prevê o investimento de 2.250 milhões de cruzeiros. Nesse investimento deixaram-se explicitamente de fora "as pequenas granjas do tipo de empresas familiares", que poderão obter, "provavelmente com maior conveniência", apoio financeiro de bancos comerciais, com recursos próprios ou mediante repasses ao Sistema Financeiro de Crédito Rural. "Por este motivo, o presente programa optou por apoiar somente as empresas integradas de produção e de abate de frangos de corte", considerando-se para isso a expansão das granjas integradas com a indústria de abate 
juntamente com fábricas de rações (BDMG, 1980, pp. 122-40).

Do lado da integração horizontal, atua de modo especial a Emater/MG, articulando os pequenos e médios produtores aos frigoríficos e grandes empresas, em sua função social de "difundir tecnologia agropecuária e gerencial, operacionalizando-a a nível de produtor através de cursos, reuniões, palestras, demonstrações de métodos e resultados". No setor avícola encontra-se metade dos técnicos com que a Emater/MG conta dar apoio à agropecuária em geral em Minas, possuindo uma coordenadoria estadual de avicultura e 13 regionais e cerca de 170 escritórios no interior do Estado, atingindo 1.615 avicultores em 1979. Através dessa rede de escritórios, a Emater é o órgão no Estado que está mais em dia com as informações sobre avicultura, recebendo semanalmente dados sobre o setor nas diversas regiões do Estado.

\subsubsection{A INTERMEDIAÇÃO EM MINAS}

Nas páginas anteriores fizemos menção freqüente a dois traços característicos da estrutura da produção avícola em Minas. Por um lado, a tendência à integração vertical em anos recentes com base em grandes empresas avícolas e, por outro, a não-existência da modalidade de integração horizontal por contrato em sentido forte, mas apenas parcial, onde o contrato de fornecimento do produto por parte dos produtores a um determinado abatedouro ou frigorífico não cria necessariamente uma obrigação formal entre ambos, sendo apenas um arranjo pessoal entre as partes, e que pode ser desfeito sem maiores conseqüências. Adquire importância, nesse contexto, a figura do intermediário/atravessador, produto, em boa medida, da existência de um grande número de pequenos produtores "independentes". A seguir, procuraremos tecer alguns comentários sobre algumas particularidades dessa forma de organização da produção, com base em entrevistas diretas com produtores e contatos com técnicos que operam no setor avícola.

A decisão de entrar no ramo da produção de frangos de corte, por exemplo, obriga necessariamente o indivíduo a ter de decidir sobre a aquisição de pintos, de ração, de assistência técnica e de medicamentos, de transporte e venda do produto. Em situação de integração completa esses elementos não apresentam maiores complicações, uma vez que a empresa integradora os adianta ao produtor em troca do fornecimento exclusivo do produto a um preço estabelecido.

Em Minas, como se verá adiante, o único caso desse tipo de integração é o do frigorífico Rio Branco, que iniciou experiência, há cerca de um ano, com integrados. Desse modo, e com exceção das empresas totalmente verticalizadas, os avicultores mineiros em sua grande maioria, especialmente os pequenos, estão totalmente "flutuantes", sem contrato com frigoríficos e dependentes de uma complexa variedade de articulações para aquisição de insumos e venda do produto, produzindo o contexto para o surgimento do intermediário ou atravessador. A integração parcial que existe com 
abatedouros e frigoríficos se dá através do contrato de compra da produção prefixada ao preço vigente no dia na Bolsa de Frangos. Esse preço é decidido semanalmente pela Bolsa de Frangos e Ovos que funciona junto à Associação de Avicultores de Minas Gerais. É de notar que esse preço estabelecido pela Bolsa é apenas indicativo do preço a ser pago aos produtores sem contrato prefixado de venda, podendo variar tanto para baixo como para cima, dependendo da concorrência entre abatedouros e atravessadores, e do modo como ambos são capazes de especular junto aos produtores com a situação do mercado.

O modo de se efetuar a indicação do preço pela Bolsa já é um indício do controle e pressão exercidos pelos abatedouros e atravessadores pelo rebaixamento dos preços. A Associação dos Avicultores é constituída por membros que são pessoas físicas ou jurídicas no setor de avicultura, dela fazendo parte tanto produtores diretos como abatedouros e frigoríficos, industriais de ração, de medicamentos, técnicos avícolas etc., o que já demonstra uma vasta heterogeneidade de interesses representados pela Associação. Se, em 1975, a AAMG possuía apenas 196 sócios, dela hoje são membros 937 associados representando cerca de 65\% dos produtores avícolas e mais de $85 \%$ dos vários interesses ligados ao setor de aves no Estado.

Numa reunião normal da Bolsa de Frangos, por exemplo, os associados presentes discutem de início, aleatoriamente, com o presidente, a situação de oferta e procura, que consiste em alguns dos presentes indicarem se têm previsão de maior ou menor quantidade de aves a levar aos abatedouros com relação à semana anterior. A partir dessa rápida alusão à oferta, o presidente escolhe uma comissão de seis associados, sendo três produtores e três donos de abatedouros, com a função de proporem o preço para o quilo de frango e votarem em seguida, sendo o do presidente o voto que decide em caso de empate. Ao se observar uma reunião da Bolsa, fica evidente a pressão dos abatedouros e atravessadores por manter os preços baixos, como também seu controle sobre a Bolsa, especialmente em situação de crise, quando, segundo informação de técnico avícola, os atravessadores comparecem em maior número, pois têm interesse em manter preços baixos. Presentemente, por exemplo, o próprio presidente, além de produtor, é também comerciante de ração e atravessador no comércio de aves.

O atravessador é basicamente a firma com frota de transporte que adquire aves ou ovos diretamente dos produtores e, conforme o mercado, faz um jogo especulatório na colocação do produto no destino de abate (frangos) ou no mercado atacadista (ovos), ora comercializando na região, ora estendendo esse comércio a outras regiões e para fora do Estado. A isenção do ICM interestadual para frangos e ovos facilita essa operação, pois o produto passa a transitar sem documentação fiscal emitida pelo produtor, gerando ao mesmo tempo risco comercial para os avicultores, pois suas produções são entregues a terceiros, os intermediários, contra um simples vale 
manuscrito. Nesses casos os prejuízos aos produtores advêm do desaparecimento de partes da carga durante o trajeto, argumentando-se posteriormente na origem, como mortes, descartes, condenação das aves etc., sem que o produtor possa ser indenizado (Fernandes e Ferreira, 1981, p. 15). A nãoemissão da nota fiscal pelo produtor nessa operação com o atravessador livra o primeiro, por outro lado, do pagamento do Funrural, que em março de 1981 significava cerca de 5\% do preço do frango.

Os principais fornecedores de aves e ovos aos intermediários/atravessadores são pequenos produtores e aqueles produtores sem contrato com abatedouro. Freqüentemente o próprio atravessador é o que fornece ração para o produtor, especialmente ração pronta, que encarece em mais de $10 \%$ os custos de produção. Como a maioria dos produtores desconhece os custos de produção (79\% dos avicultores da região Centro, a mais antiga produtora de aves em Minas, desconheciam esses custos segundo dados de 1977, contra 57,69\% e 73,12\% da região Sul e da Zona da Mata, respectivamente), o atravessador também defrauda o pequeno produtor nos custos e na conversão alimentar, pois é o atravessador que freqüentemente orienta o produtor no uso da ração. Sendo o ideal 2,2kg de ração para frango de corte, o atravessador indica-lhe uma conversão maior, 2,6, por exemplo, como se constatou em Pará de Minas, além de medir a quantidade desta para 57 dias, quando 52 seria o ideal. Além dos ganhos que obtêm nessa transação e do controle que o intermediário acaba exercendo sobre os produtores, seus lucros ainda advêm de não necessariamente repassarem aos produtores os descontos que obtêm das fábricas de ração como grandes consumidores que são.

E interessante notar, por fim, que também um abatedouro de frangos pode funcionar como uma espécie de atravessador entre determinada fábrica de ração e um incubatório e os produtores, recebendo uma comissão de $2 \%$ de ambos em troca de vincular os produtores quer à fábrica quer ao incubatório. Conforme informação obtida, quatro casos desse tipo de "falsa integração" estariam sendo processados atualmente em Pará de Minas. O sentido principal dessa transação em que abatedouro, fábrica de ração e incubatório se associam para "integrar" o produtor é francamente especulativo e exploratório do produtor, onde este é utilizado como elemento que viabiliza o consumo dos serviços de que a fábrica de ração e incubatório dispõem, possibilitando ainda um lucro adicional ao abatedouro. Em situações de baixa de preços, os frigoríficos se aproveitam para formar estoques que serão vendidos na alta. ${ }^{20}$ Esses estoques servem igualmente como instrumento de pressão econômica sobre o produtor rural que não tem condições de "armazenar" sua produção.

À forma "pulverizada" de pequenos produtores "autônomos" em que se estruturou a

\footnotetext{
${ }^{20}$ A maioria dos frigoríficos, em tempos normais, não utiliza grande parte de sua capacidade instalada.
} 
produção avícola em Minas e que possibilitou a diversidade de articulações e intermediações "especulativas" nas relações de produção mencionadas acima, parecem estar ligadas também certas características da rede de abate no Estado, também "pulverizada" numa grande quantidade de abatedouros considerados "irrecuperáveis" (101, de um total de 116 no Estado), e pouco condizentes com o nível de sofisticação industrial a que chegou a avicultura. Apesar da sua expressiva significação na quantidade aves/ano abatidas (17 milhões de um total de 60 milhões no Estado) esses "postos de abate" se caracterizam por "reduzidas dimensões, falta de equipamentos apropriados à operação, sendo a grande maioria localizada no quintal do proprietário ou em terreno contíguo à sua residência, com as várias atividades do estabelecimento realizadas pelo próprio dono e seus familiares". Segundo avaliação de técnicos do BDMG, "esses postos de abate, além de não atenderem aos requisitos técnico-sanitários para exportação dos excedentes, concorrem com os matadouros-frigoríficos, não só pela insignificância dos investimentos realizados naqueles, como também porque os "postos de abate" não pagam taxa de inspeção e não têm condenação de carcaças para o consumo humano... além do mais, esses "postos de abate" geralmente descumprem as legislações vigentes na área trabalhista e fiscal, bem como as normas de controle e poluição ambiental" (BDMG, 1980, pp. 102-03). Em vista disso, o BDMG se dispunha, no seu programa para avicultura, a investir Cr\$ 880.500.000,00 para recuperação, adaptação, reativação ou expansão de nove matadouros-frigoríficos já existentes e construções de outros sete novos, no período 198083.

Restaria mencionar aqui, talvez como um dos fatores explicativos da persistência da sujeição dos pequenos avicultores à rede de intermediação e exploração a que estão expostos em Minas, as relações de dependência pessoal que facilmente se estabelecem entre atravessadores, por exemplo, e produtores. Conforme entrevistas com pequenos produtores e informações de técnicos, essa sujeição é difícil de desfazer, entre outras razões, pela possibilidade de favores pessoais que os intermediários comerciantes geralmente passam a prestar aos pequenos produtores: além de informações sobre manejo da granja, por exemplo, transportando-lhes pequenas encomendas da cidade, botijão de gás etc., assegurando e repassando crédito e atendendo necessidades de transporte que seu isolamento no meio rural dificulta satisfazer por conta própria. Nesse sentido, parecem readaptar-se, como no caso da produção avícola moderna, as formas de dominação tradicional tão conhecidas na agricultura brasileira, possibilitando maior exploração econômica dos produtores diretos.

Em certas condutas e motivações mais particularmente especulativas e de exploração direta dos pequenos avicultores por parte do capital comercial, financeiro e industrial ligado ao setor avícola em Minas, parece residir, por outro lado, uma das dificuldades de se estabelecer, no Estado, 
a integração horizontal por contrato nos moldes em que isso se dá em Santa Catarina. Segundo comentários de técnicos da Emater/MG, que têm procurado programar junto ao capital industrial a integração por contrato dos produtores, os empresários do setor em Minas estão pouco propensos a conceder algum benefício aos produtores e só interessados em ver na operação os lucros imediatos. Nesse caráter "empresarial mineiro" mais claramente lesivo ao produtor (síndrome talvez da atitude especulativa através de arranjos pessoais da intermediação, como discutida acima) parece estar uma das causas da inexistência, em Minas, de integração horizontal completa, mais do que nas explicações oferecidas por empresários que se referem à atitude individualista do pequeno produtor mineiro ou ainda à inexistência de uma estrutura fundiária de pequenos camponeses.

A esse aspecto negativo à integração horizontal parece juntar-se outro no mesmo nível, o da ainda fraca centralização dos frigoríficos a ponto de centralizar as decisões estratégicas frente ao campesinato, como se depreende do fato de que dos 116 abatedouros/frigoríficos no Estado, apenas oito possuíam inspeção federal em 1979, sete podiam ser recuperáveis e 101 eram considerados irrecuperáveis e de características domésticas do pequeno capital comercial (BDMG, op. cit.).

Situação diferente é apresentada pela empresa Rio Branco. Juntamente com granjas próprias para plantéis de 125 mil matrizes e 800 mil frangos de corte, a Rio Branco possui hoje plantel de 1.800.000 aves de corte no sistema de integração por contrato, utilizando 130 produtores com contrato firmado em cartório, com o objetivo principal de produção para exportação, sendo $80 \%$ destinados ao Oriente Médio. É significativo o fato de que seus integrados se localizam num raio de até $180 \mathrm{~km}$ do frigorífico central, e, conforme informação direta, pretende estender-se até Pará de Minas, distante cerca de $500 \mathrm{~km}$ da sede. A integração teve início em forma experimental no final de 1980 com cerca de 80 integrados, e só em março de 1981 estava implantada em forma acabada com 180 integrados, sendo que, segundo a empresa, o número de integrados para o futuro não tem limites.

A empresa fornece diretamente ao integrado pinto, ração, medicamentos, vacina, assistência técnica semanal e transporte, além de pagar o Funrural. No contrato firmado em cartório e válido por 18 meses, está estipulado um preço mínimo por frango, além de uma cláusula de reajuste, com base num fator de produção. Esse fator de produção estabelece que o integrado deve produzir em 49 dias um frango de $1,650 \mathrm{~kg}$ de peso com conversão alimentar de 2,1. O integrado que atinge esse fator recebe por ave $\mathrm{Cr} \$ 7,20$. Segundo avaliação de técnico avícola com amplo conhecimento direto das condições de produção dos mais variados estratos de produtores avícolas no Estado, essas condições de contrato são relativamente favoráveis aos integrados. Tanto é assim que mais de 70\% dos integrados em outros moldes, da Cooperativa Comasa, no município vizinho de Leopoldina, já foram atraídos para a Rio Branco. Por outro lado, com base nos critérios acima referidos, a empresa 
tem possibilidade de selecionar seus integrados, findos os prazos de vigência do contrato. Por exemplo, até agora, $75 \%$ dos integrados conseguiram atingir $80 \%$ do fator de produção, sendo que $25 \%$ superam esse índice, e a empresa pretende eliminar cerca de $10 \%$ dos que tinham sido integrados. Segundo foi informado, a maioria dos produtores está satisfeita com a condição de integrados, só reclamando os que não conseguem aquele fator de produção. Apesar de a empresa integradora não estimular o cultivo de milho por parte dos seus integrados, quem quiser pode fazêlo e se o utilizar como ração, será ressarcido ao preço do mercado (Entrevista, junho de 1981).

\subsection{TRANSFORMAÇÕES DA EMPRESA FAMILIAR PELA AGROINDÚSTRIA}

\subsubsection{PROCESSO DE TRABALHO E APROPRIAÇÃO DO CONHECIMENTO} CAMPONÊS

Apesar das diferentes formas de integração, como acabamos de ver acima, emergem dentro delas certas características comuns às empresas rurais articuladas ao complexo agroindustrial. Para o produtor familiar, e também para o trabalhador assalariado, as formas tradicionais de produção mantinham um controle do processo produtivo a partir do conhecimento adquirido na prática e das características técnicas da produção. O que fazer, quando fazer e como fazer eram em grande parte determinados pela sua "intuição", desenvolvida a partir da experiência acumulada.

Nas condições de produção tecnificada, e particularmente no caso da avicultura, o processo produtivo passa a estar determinado pelas prescrições "externas" das empresas industriais que estruturam o ritmo e as tarefas da atividade produtiva. Como alimentar, a preparação da alimentação, quando e como distribuir, o tratamento do frango, o que fazer em casos de doenças etc. são determinados pelos técnicos das empresas integradoras ou pelos vendedores do setor avícola industrial ou dos órgãos oficiais de assistência. Em qualquer um dos casos, os porquês das prescrições técnicas permanecem desconhecidos para o trabalhador rural, que, no fundamental, segue as indicações dos técnicos, sob pena de produzir resultados econômicos insatisfatórios.

Não somente o conhecimento é subtraído do produtor, como seu ritmo de trabalho passa a ser determinado pelas prescrições técnicas da agroindústria. O delicado material genético com que ele trabalha, além da racionalização no uso dos insumos (quantidade certa distribuída em períodos prefixados), determinam que o ritmo do trabalho e sua distribuição estejam em grande parte fora do controle do produtor.

A desapropriação do conhecimento tradicional e a imposição do ritmo de trabalho não implicam que o trabalhador avícola não possua ainda certas características e conhecimentos que lhe 
são próprios. O trabalho rural avícola exige do trabalhador certas características na sua capacidade de manuseio das aves, que são adquiridas pela experiência nesse campo. No trabalho avícola, a experiência adquirida permite ao produtor rural - embora este não controle, e até desconheça as especificações técnicas dos produtos utilizados - introduzir de forma intuitiva pequenas modificações na utilização dos insumos. Trata-se, porém, de limites muito estreitos de autonomia no processo produtivo, sem lhe dar reais condições de influir seja nas determinações mais gerais da utilização dos insumos industriais, seja na aplicação de capacidade inovadora.

Particularmente, nas condições de "transição acelerada", de camponês tradicional, com praticamente nenhuma educação formal, para as formas avançadas da agricultura industrial, o produtor não tem condições de acompanhar, de integrar níveis mais abstratos de informação relativos à tecnologia por ele utilizada.

O ritmo de trabalho, embora não seja totalmente imposto pelo ritmo da maquinaria, não deixa para o produtor maiores margens de autonomia, sob pena de não cumprir os níveis de produtividade que são a condição de sobrevivência econômica. Ainda mais: por estar impossibilitado de contratar um número suficiente de trabalhadores assalariados, tem que assumir tarefas que vão muito além de uma jornada normal de oito horas de trabalho.

O caso da avicultura demonstra empiricamente a limitação das hipóteses apresentadas por Mann e Dickinson (1978) para explicar a inexistência de um processo de proletarização no campo. Para esses autores, o capital teria dificuldades de entrar no campo pelo caráter sazonal da produção agrícola, implicando uma ociosidade do capital fixo durante parte considerável do ano. Isso resultaria numa baixa rotatividade do capital, afetando, por sua vez, a taxa de lucro na agricultura.

A demonstração teórica dos erros implícitos nesse tipo de argumento já foi realizada em outro lugar. O que convém sublinhar aqui é que a avicultura é um setor onde foi praticamente eliminada a ociosidade do capital fixo, mas ainda segue sendo um setor onde a produção familiar, senão dominante, é ainda viável. A permanência da produção familiar no campo deve, portanto, ser procurada em outro lugar. ${ }^{21}$ No presente trabalho indicamos as condições históricas que tornam possível a existência da produção familiar integrada à agroindústria.

\subsubsection{O SENTIDO DA INTEGRAÇÃO}

As empresas integradoras apontaram em entrevistas como principais vantagens do sistema de integração: matéria-prima (o frango) de maior qualidade de rendimento industrial $(92,3 \%$ dos entrevistados), abastecimento constante da matéria-prima qualificada (92,3\%), redução dos custos

\footnotetext{
${ }^{21}$ Sobre essa questão, consultar Goodman, Sorj e Wilkinson (1982).
} 
industriais nas operações de abate e elaboração da matéria-prima (84,5\%), padronização das carcaças $(75,9 \%)$ e redução de espaços, tempo e capital de giro necessário para estocagem e matéria-prima no período anterior ao abate (46,2\%) (Cebrae/Ceag-sc, 1978, pp. 80-86).

Ainda de acordo com essas análises, as "principais vantagens dos produtores com este sistema de integração podem ser resumidas nos seguintes itens: assistência técnica intensa e permanentemente atualizada; formação de um plantel básico de reprodutores de alto valor zootécnico; utilização de equipamentos e insumos de qualidade, inclusive rações e concentrados de alto valor nutricional a preços mais acessíveis; utilização racional de crédito rural orientado; maior produtividade; redução dos custos de produção e maior rentabilidade; melhor preço médio de venda; melhor aproveitamento dos recursos disponíveis na propriedade (terra, capital e trabalho); adição e dimensionamentos adequados, com elevação de renda líquida anual e capacitação profissional do produtor" (Cebrae/ Ceag-SC, 1977, pp. 22-25).

Entretanto, partimos do pressuposto de que tanto as estratégias particulares como as estratégias globais do capital integrador e as respectivas condições e formas de relações integrador/integrado (contratualmente ou não), antes de serem determinadas por cálculos de rentabilidade, são produtos das condições históricas da formação e desenvolvimento tanto do capital integrador quanto da estrutura agrária a ser integrada. Em outras palavras, frente às condições técnicas à disposição do capital e às condições naturais da produção agropecuária, o capital integrador possui uma gama de alternativas estratégicas, dependentes do contexto de uma dada estrutura social no campo. Por sua vez, os produtores integrados desenvolvem estratégias ou respostas negativas, como, por exemplo, sua insolvência enquanto produtor rural integrado, o rompimento das relações contratuais pelo descontentamento, a desistência de continuar sendo produtor e passar a ser operário na própria agroindústria e/ou nas atividades urbanas, a formação de associações de criadores com razoável poder de barganha frente às empresas integradoras etc.

Frente a isso a empresa integradora contaria com a possibilidade do aumento da produção média dos produtores ou assumiria, diretamente, a produção de aves:

(...) Outra maneira de contornar o problema do êxodo de produtores da integração é dada pela própria evolução tecnológica da produção agroindustrial. Poderá chegar o momento em que parte do processo tenha que ser internalizada pelo frigorífico como única opção de incorporar a renovação tecnológica. Parece que isto já está ocorrendo com a produção de aves; a diminuição do período de desenvolvimento para corte, a automatização dos aviários etc. possibilitam maior rentabilidade do capital. Além do que, o valor das instalações e equipamentos tecnologicamente sofisticados pode se tornar impeditivo a pequenos produtores (ibid., pp. 24-26).

De tudo isso se conclui que o sistema tenderá a evoluir no sentido de uma incorporação maior de produtores e/ou de um aumento da produção de integrados no consumo total de matérias-primas dos frigoríficos. O frigorífico tem a seu favor, ainda, o fato de que o número de produtores que procuram se integrar é relativamente grande, o que 
compensaria qualquer saída, mas o produtor rural tem ainda contra si um fator que lhe impõe a imobilidade para sair do esquema contratual: é a dependência que lhe criam as instalações agrícolas, por um lado, impedindo-o de sair da atividade suinícola ou avícola, e, por outro (o que ocorre em muitos casos), o grau de endividamento em que se encontra junto ao frigorífico ou ao banco financiador de suas instalações não lhe permite qualquer esforço para mudar de atividades (ibid.).

De qualquer modo, para a pesquisa citada, em Santa Catarina apenas 5\% da produção de aves se davam internamente, ou seja, pelo próprio abatedouro, e, segundo os cálculos, para que as empresas integradoras produzissem toda a matéria-prima através da integração vertical, seria necessária uma imobilização de capital para investimentos em terra e instalações superior ao total do capital social das empresas.

De qualquer maneira, o elemento básico para a explicação da formação da agricultura de integração, seja contratual ou não, está nas condições macrossociais e históricas, de onde emanam as condições concretas e imediatas para as diferentes estratégias e arranjos entre integradoras e integrados. E os elementos básicos resultantes do tipo de formação histórica da agropecuária do Sul do Brasil foram a preexistência de uma massa de produtores rurais com determinadas condições de produção em quantidade superior às necessidades imediatas do capital integrador e a disposição desses produtores em não contarem com uma taxa de remuneração do capital fixo da venda da terra. A preexistência de um campesinato à disposição do capital integrador é reforçada com sua relativa imobilidade, enquanto o capital integrador possui uma mobilidade espacial e setorial maior. Um dos exemplos mais claros da determinação social das formas de integração pode ser extraído da contraposição da avicultura catarinense, já formada sob a égide do capital integrador, com a avicultura industrial mais antiga, ou, ainda, com a avicultura formada já com base na grande empresa. Um dos exemplos deste último caso é a Granja Rezende, que, segundo seu diretor: "Antes de nos decidirmos pela verticalização, discutimos a adoção do sistema de integração, utilizado pela Sadia e pela Perdigão" (empresas que dominam, conjuntamente, 30\% dos abates de suínos e aves do país). "Mas como no Triângulo Mineiro não há minifúndios, só latifúndios, acabamos por investir na verticalização, que deu ótimos resultados" (Negócios em Exame, 22 de outubro de 1980, p. 44). É significativo que praticamente a totalidade da produção industrial de aves e também de suínos no Sul se localize nas regiões caracteristicamente de menor propriedade rural.

Por sua vez, a tendência da avicultura industrial à integração horizontal, nas regiões em que preexistia uma avicultura relativamente forte, tem provocado fortes reações desses setores, especialmente em São Paulo. A julgar pela reação das associações mais atingidas pelo avanço da integração, os "avicultores independentes não têm perspectivas de manutenção de suas atividades, tanto pela crise conjuntural que o setor e o país atravessam, como pela atuação das empresas 
integradas de avicultura, que visam ao controle do mercado, segundo o presidente da União dos Avicultores de Corte (Unac). Em palestra realizada no Primeiro Seminário de Economia Avícola, o empresário defendeu a livre iniciativa e previu um conflito político no setor, caso as dificuldades atuais não sejam distribuídas de forma equilibrada". Na mesma ocasião houve um confronto com os defensores da integração através de um diretor da Sadia Agropastoril e avicultores independentes (Folha de São Paulo, 5 de dezembro de 1980).

Essa tendência ou avanço da integração é apoiada inclusive por setores produtores de insumos, como a For Agro. Segundo um de seus diretores, ao "(...) produtor pequeno - aquele que cria menos de 50 mil frangos e não possui instalações adequadas ou o mínimo de estrutura de capitalização, é vedado o milagre da economia, como a todos em situação semelhante, de fabricar sua própria ração (...). Aos portadores de tais benesses, contudo, um novo mundo de economia de escala, lucros, lhe será outorgado a um simples telefonema" (Avicultura Industrial, janeiro de 1981, p. 14). Esse "novo mundo" seria a integração, que, com um telefonema à empresa integradora, esta se encarregaria do fornecimento dos insumos e da assistência técnica ao produtor integrado.

Outro setor dos que reagem mais fortemente contra a tendência à integração é a Comissão Técnica da Avicultura da Federação da Agricultura de São Paulo. Conforme seu presidente, Flávio Fernandes, um dos responsáveis pelo avanço da integração, é a crise que elimina da concorrência os pequenos e médios empresários. Para ele, "as altas constantes dos insumos promovem a descapitalização do criador de aves: sem financiamento e capital de giro ele acaba perdendo o emprego. (...) Vê-se, portanto, frente a duas opções, nenhuma delas particularmente atraente: arrenda sua propriedade ou passa a fazer parte de um esquema de integração. (...) A integração é a solução a curto prazo. (...) A médio prazo a coisa se complica: como conseqüência desta absorção, a faixa dos pequenos e médios empresários avícolas pode desaparecer, restringindo a disputa pelo mercado apenas a grandes empresas. (...) A integração é um processo irreversível. (...) O avicultor se torna um assalariado. E, em contrapartida, as empresas continuam isentas de obrigações sociais para com ele". Segundo o presidente, a integração não resolveria os problemas, tuas os transferiria para o futuro. A melhor solução seria não aplicar o modelo norte-americano de integração como está ocorrendo no Brasil; "Acho, porém, que teremos um meio-termo entre as duas integrações, dadas as características internas de nosso país" (Dirigente Rural, maio de 1980).

No Sul, como não preexistia uma avicultura industrial consolidada em outras bases de organização e levando-se em conta a estrutura produtiva e social da agropecuária, essas reações contra a integração não existem. As reações, quando existem, são por melhores preços para a produção entregue à empresa integradora. É interessante notar que empresas que propagam e implantam a integração horizontal no Sul, como a Sadia, em outras regiões, como em Goiás, 
implantam a integração vertical.

Cabe esclarecer que essa divisão social do trabalho entre a unidade produtiva agropecuária e a empresa integradora não atinge necessariamente toda a gama de linhas de produção a cargo da agropecuária, pelo menos no mesmo grau. Concretamente, pode acontecer que a alta especialização e a integração de aves, por exemplo, mantenham e mesmo desenvolvam as demais produções da unidade produtiva, inclusive como estratégia do próprio capital integrador e do produtor integrado, na medida em que a pecuária leve, em geral, e a avicultura são altamente consumidoras, também, de insumos de origem agropecuária. Isso faz com que a produção de produtos como o milho passe a ser essencial, pelo exposto, e, inclusive, porque pode se constituir numa estratégia por parte do capital produtor para o rebaixamento dos custos monetários da produção. Mesmo assim, isso não quer dizer que a unidade produtiva avícola integrada necessite de uma relativamente grande área de terra, visto que a produção desses insumos de origem agropecuária é intensiva.

\subsubsection{SELEÇÃO - CONCENTRAÇÃO - EXPULSÃO}

Como vimos, a avicultura integrada exige, além da existência de uma massa de produtores rurais em condições sociais inferiores, um contingente de produtores rurais aos quais o conjunto das condições sociais não oferece alternativas melhores que a produção integrada.

O que importa reter é que a integração horizontal supõe a existência de unidades produtivas "em excesso" relativo para serem integradas, de forma semelhante à necessidade de força de trabalho livre excedente para o bom funcionamento do trabalho assalariado para o capital. Por isso, a integração horizontal na avicultura industrial ou outra linha de produção integrada não depende apenas das condições sociais dessas produções, mas ainda das condições sociais para o conjunto das linhas de produção semelhantes.

O importante a reter do processo histórico de ocupação do solo nas condições brasileiras é seu duplo caráter "compressor". Essa compressão, no tocante à ocupação do solo, pressiona no sentido da deterioração gradativa das condições sociais de produção (pauperização) da parte dos pequenos produtores em piores condições, pela própria escassez relativa da terra, que se constitui no principal meio de produção na agricultura tradicional. A essa crescente pressão sobre a terra por parte da pequena produção se agregam a relativa rigidez econômica e institucional da grande propriedade fundiária, baseada na exploração extensiva e ocupando as melhores terras (pastagens, reservas de madeiras etc.) e o paulatino esgotamento e/ou aumento da seletividade no acesso à fronteira agrícola. Esse fenômeno manifesta-se particularmente na crescente subdivisão das pequenas propriedades rurais, num primeiro momento, e na progressiva marginalização em massa da parte mais "débil" do campesinato, repetindo, numa outra fase histórica, um fenômeno 
semelhante à antiga exclusão social dos ex-escravos, assalariados, agregados, meeiros etc., do latifúndio predatório.

A esse processo histórico une-se outra fonte de "compressão" que se consolida como determinante na reorganização da estrutura agrária na fase atual e cuja vertente é o desenvolvimento do capital e o progressivo aumento e diversificação de suas pressões sobre a estrutura agrária. No caso do Sul do Brasil, o conjunto de capitais com interesses vinculados à agropecuária encontra uma estrutura agrária diversificada e com uma parte extremamente comprimida, o que define o espaço para as estratégias dos diversos blocos de capital que atuam sobre ela. O efeito da atuação do capital agroindustrial sobre a estrutura agrária é seletivo por sua própria natureza, redefinindo, mas não eliminando a crescente pressão sobre a terra. Em outras palavras, à competitividade histórica para o acesso à terra se acrescenta a competitividade para o acesso às novas condições de produção, condicionadas pelo desenvolvimento do capital em geral e, particularmente, pelos blocos de capital com interesses vinculados especificamente à produção agrícola.

As tendências presentes na avicultura confirmam que a agropecuária avançada apresenta claras tendências à concentração da produção sem levar necessariamente o meio rural ${ }^{22}$ à eliminação da empresa familiar. Seja como for, não deixa de ser importante assinalar que existem indícios de que os níveis de automação e os ganhos de escala tornam cada vez mais viável a granja avícola em moldes de grande empresa capitalista.

\footnotetext{
${ }^{22}$ Em trabalho anterior definíamos dois processos de transformação social no campo: diferenciação social horizontal e vertical (Sorj, 1980).
} 


\section{CAPITULO 3}

\section{ENTRE O OVO E A GALINHA: INTERMEDIAÇÃO E REPRESENTAÇÃO POLÍTICA NA AVICULTURA BRASILEIRA}

\subsection{ARTICULAÇÃO ESTADO/ECONOMIA}

A representação e realização de interesses na moderna avicultura brasileira se inscreve nos moldes do Estado autoritário. A readequação sócio-econômica gestada desde os anos 1950 e consolidada, a partir de 1964, no novo regime político trouxe em seu bojo a redefinição também do exercício do poder. Se bem que a avicultura, por si só, não chegue a constituir um setor particularmente importante da economia, ela se configura, no entanto, como um dos exemplos mais notáveis da articulação entre o moderno capital ligado à agricultura e o Estado, como também das novas formas de representação política de interesses.

A articulação entre capital estatal, capital multinacional e capital privado nacional em termos de economia brasileira em geral já foi examinada em outros trabalhos (Cardoso, 1975). O que cabe reter aqui é que, na articulação dessas novas formas de capital, se cristalizam dois aspectos sócio-econômicos do capitalismo associado-dependente diretamente vinculados ao tema em questão. Primeiro, essa articulação se dá no conjunto de transformações socioeconômicas que implicam um novo patamar técnico-econômico, o qual aponta para a progressiva oligopolização. $\mathrm{O}$ segundo aspecto a ser ressaltado é o crescimento da participação estatal, quer diretamente como "empresário-associado" ou como "fiador" e garantidor do crescimento econômico e do ordenamento político-institucional.

No caso da avicultura industrial, é substancialmente sob a forma de "fiador", no sentido de criar as condições econômicas da acumulação e de garantia de ordenamento político-institucional, que o Estado atua mais diretamente. A avicultura industrial é um setor inexplicável se se abstrai do componente Estado. Ao recriar as condições sócio-econômicas para a acumulação, o Estado cria também as condições para a associação ou a articulação com o capital externo e para o avanço no sentido de centralização e dinamização do moderno capital.

Nos rearranjos político-institucionais inaugurados em 1964, dois aspectos precisam ser ressaltados para a apreensão das formas de representação e realização de interesses na avicultura industrial. De um lado, com a obstrução dos canais políticos tradicionais, tanto o Estado quanto as classes e grupos hegemônicos recriam ou reforçam novos meios de intermediação entre as esferas de realização do capital e as instâncias decisórias. Esse rearranjo implica a reestruturação e reaparelhamento do Estado e o redimensionamento ao nível de aglutinação e organização de interesses e pressões sociais. Essa aglutinação é objetivada particularmente nas "associações" e em 
sua articulação com os órgãos oficiais. Na reestruturação dos novos canais políticos efetivos e em seu comportamento, está implícita - como "lei não-escrita" - uma determinada "racionalidade" que filtra e dita a relevância das questões que emergem do processo de acumulação e conseqüentes transformações sociais.

O princípio básico da lógica dessa "racional idade" implícita na organização e exercício do poder é que as bases, tanto sócio-econômicas quanto político-institucionais, já estão dadas. Ao se optar por determinado tipo de capitalismo e ao se empenhar o Estado em sua viabilização, as questões que poderiam emergir e, portanto, requereriam tomadas de posições e decisões, são exclusivamente questões referentes a "desajustes" e "estrangulamentos" de seu funcionamento. Esse tipo de racionalização foi assumido não apenas pela tecnoburocracia estatal, mas pelo conjunto das organizações privadas. Desse modo, o critério básico, ao nível político-ideológico, para que determinada questão passe a ser considerada, é que esteja vinculada ao "bom funcionamento da sociedade", isto é, à racionalização do capitalismo associado-dependente.

É nesse quadro, onde a economia se "politiza" e onde a política se "administraliza" - na medida em que está assentada na "racional idade" apontada acima -, que alguns autores a percebem despolitizada. De acordo com esse ponto de vista, as classes sociais que dão suporte ao Estado autoritário teriam relegado à burocracia militar o controle e a administração do poder. Em outras palavras, as classes que controlam a sociedade brasileira teriam abandonado a pretensão de serem poderosas para serem ricas (Forman, 1979, pp. 248-49). Ora, numa economia cuja dinâmica internacionalizante articula o capital com apoio estatal, seu móvel básico, sua própria orientação é resultante da interação político-institucional empresa/Estado. Essa mesma interação é urna tomada de posição política que requer um profundo e permanente entrosamento entre esferas do poder público e do capital, tanto ao nível socioeconômico quanto político-institucional. As decisões políticas se transfiguram em medidas econômico-administrativas.

Essa readequação dos canais políticos - juntamente com sua "racionalidade" implícita assenta numa base social cuja dinâmica de transformação envolve tanto a progressiva centralização e oligopolização do capital quanto a redefinição da estrutura das classes trabalhadoras. Especificamente no tocante ao complexo avícola industrial, as transformações das condições sociais dos trabalhadores agrícolas são extremamente complexas, por abrangerem uma série de formas de subordinação do trabalho agrícola ao capital. De qualquer modo, as duas formas básicas são representadas pela subordinação do campesinato, através da integração horizontal, e pela sua proletarização, através da integração vertical.

O que importa reter dessas formas de subordinação do trabalho ao capital, para os fins aqui propostos, é que a fonte maior de tensões sociais nem chega a ser a subordinação do trabalho ao 
capital. Num nível mais imediato e mais dramático, a principal fonte de tensões sociais é a seleção/ exclusão em massa do antigo campesinato que não possui condições socioeconômicas para se integrar e subordinar, de acordo com os requerimentos do capital e da tecnologia postos em prática. Essa eliminação do antigo campesinato contrapõe-se à diminuição relativa das necessidades de mão-de-obra por parte do moderno capital, tanto industrial quanto agrícola. A relevância desses elementos para a apreensão do exercício do poder na avicultura é resultante da utilização política dessas condições sociais. Pode parecer paradoxal, mas ao "afunilamento" em termos socioeconômicos - na medida em que as condições sociais abrangem desde produtores rurais camponeses relativamente estabilizados economicamente até produtores em deterioração ou em via de marginalização social - corresponde um afunilamento político.

São esses setores "excluídos" dos círculos de decisão efetiva os que são representados formalmente por outro tipo de "associações", como os sindicatos e/ou setores de igrejas. Suas reivindicações escapam à lógica estrita da reprodução do capital e são toleradas até o ponto em que não ameacem a viabilização político-institucional da produção.

Uma outra ordem de transformação sócio-econômica na base social dessa forma de exercício do poder é constituída pelo processo de concentração e centralização, acompanhado pela internacionalização do capital. Esse processo constitui-se na fonte de um conjunto de falsas questões, de caráter puramente ideológico, que considera como sendo a "eliminação" da pequena e média empresa de capital privado nacional a grande contradição social. Também na avicultura existe um violento processo de centralização e, portanto, de desaparecimento e/ou readaptação das empresas capitalistas sem condições de acompanhar os novos patamares técnico-econômicos. Mas isso não significa que haja antagonismo irredutível entre essas categorias de capital, apesar dos conflitos permanentes. A própria articulação entre o capital estatal, internacional e privado nacional foi uma opção política e um direcionamento dado por esses componentes.

O processo de eliminação das empresas sem condições de acompanhar os novos patamares técnico-econômicos, embora implique o desaparecimento da pessoa jurídica da empresa, não significa em absoluto o desaparecimento do capital privado nacional enquanto tal. O principal equívoco na constatação do processo de centralização é a confusão estabelecida, em geral, entre a eliminação jurídica das empresas menos aparelhadas e a eliminação de seu capital e proprietários, que, na verdade, se readaptam às novas formas de acumulação. A eliminação de empresas pela centralização pode atingir um número proporcionalmente grande, como acontece atualmente com a avicultura industrial, porém, em conjunturas de rápida expansão, o próprio crescimento do setor abre espaços para a formação e expansão de novas pequenas empresas, que mais tarde passarão a se readaptar. 
$\mathrm{Na}$ avicultura industrial, o conflito entre blocos de capital se apresenta como inclusivo de diversos agentes, por se tratar de um setor formado historicamente com base no capital privado nacional, especialmente no tocante ao capital envolvido em abatedouros, a chamada indústria tradicional. No entanto, esse conflito, ao mesmo tempo em que tem sua fonte no novo patamar técnico-econômico e nas suas articulações com a internacionalização da economia, representa, também, as diferentes posições e articulações entre esses blocos de capital e o Estado.

$\mathrm{Na}$ medida em que o padrão de acumulação está assentado na articulação das diversas formas de capital, sob a égide do grande capital internacional e estatal, as vinculações e a atuação do Estado em relação às pequenas empresas possuem um caráter mais de viabilização sócio-política que estritamente econômico-produtiva. Isso não exclui, no entanto, um determinado apoio efetivo por parte do Estado às pequenas empresas, apoio esse diferenciado e seletivo, conforme a capacidade técnico-econômica de responderem a ele em seus setores específicos e ao grau de pressão política que setores representantes dessa forma de capital conseguem organizar. Embora não apresentem ameaças de ruptura com o padrão de acumulação, esses setores podem, no entanto, acumular razoável ameaça de dissensão em certas conjunturas e, por isso, o Estado formula programas específicos de apoio. Evidentemente, esse mesmo apoio tem em mira o rompimento das barreiras para que tais setores alcancem o patamar técnico-econômico do setor ou ramo produtivo. Especificamente na avicultura industrial, no caso de Santa Catarina por exemplo, a parte mais substancial do apoio às grandes empresas em sua readaptação ao novo patamar técnico-econômico teve como fonte financeira o Cebrae, ${ }^{23}$ numa conjuntura de relativa estabilidade política e crescimento econômico (Cebrae/Ceag/ SC, 1977).

Esses novos moldes de acumulação e realização de interesses estão centrados no "novo capital", isto é, no grande e moderno, seja ele de origem internacional, privada nacional, estatal, isolada ou conjuntamente. Nesse sentido haveria também um "afunilamento" no tocante à reprodução do capital, a exemplo dos camponeses e trabalhadores em geral. No entanto, ainda que o "antigo capital" não se encontre nos novos patamares técnico-produtivos, mas numa posição desprivilegiada no tocante à articulação, não está fora da "racionalidade" proposta.

\subsection{INSTRUMENTOS BÁSICOS DE REALIZAÇÃO DE INTERESSES}

Antes do exame de associativismo enquanto conduto efetivo de mediação e realização de interesses, descreveremos os principais instrumentos e políticas do Estado no sentido de criação das

\footnotetext{
${ }^{23}$ A história da formação e atuação do Cebrae (Centro Brasileiro de Assistência Gerencial à Pequena e Média Empresa) e da Comissão Permanente de Apoio à Pequena e Média Empresa confirmam o exposto (Correio do Povo, 14 de junho de 1981, p. 48; Jornal do Comércio, 25 de maio de 1981, p. 2).
} 
condições sócio-econômicas da acumulação. Focalizaremos rapidamente os créditos e subsídios à produção agrícola e ao seu processamento industrial, as políticas de exportação, de pesquisa e assistência técnica.

\subsubsection{O CRÉDITO}

O crédito direto ao complexo avícola, de um lado, tem como suporte sua vinculação com uma produção agropecuária altamente modernizada e integrada ao moderno capital industrial e às políticas de exportação. ${ }^{24}$ De outro, em sua consolidação, esse setor foi parcialmente atingido pela crise econômica e cortes na expansão do crédito. Mesmo assim, em seu desenvolvimento, o complexo avícola contou com uni lugar de destaque, tanto no crédito direto à produção agropecuária quanto nos financiamentos e estímulos à indústria processadora e às exportações.

Por suas características de pequena produção, principalmente no Sul, a avicultura se beneficiou também das mudanças na orientação da política creditícia, cujo objetivo era facilitar o acesso de pequenos produtores, em condições de modernização, ao crédito agrícola. Essa nova política creditícia tem como razões principais as limitações dos recursos disponíveis para o crédito rural e sua alta concentração. ${ }^{25} \mathrm{Na}$ tentativa de inclusão de "pequenos" estabelecimentos, o Banco do Brasil, em 1978-79, entre outras orientações, estimulou a criação de "Postos Avançados de Crédito Rural" (Banco do Brasil, 1978, pp. 20-27). Além disso, a avicultura tem maior capacidade de resposta aos estímulos governamentais, comparativamente à pecuária bovina.

Os créditos concedidos pelo Banco do Brasil à agropecuária tiveram uma expansão crescente na segunda metade da década de 1960 e na década de $1970 .{ }^{26}$ Em 1976, a avicultura ocupou 3,4\% dos empréstimos do Banco do Brasil à produção pecuária, contra 82,6\% para a bovinocultura, 3,9\% para a suinocultura e o restante para outros rebanhos. Já no ano seguinte a participação da avicultura evoluiu para 6,5\% em relação ao total, num crescimento de 139,7\%. Em

\footnotetext{
${ }^{24}$ Conforme levantamento da Federação de Associações de Bancos, em 1981, os financiamentos subsidiados abrangem cem programas, entre os quais se destacam: financiamentos de ’obras no exterior, exportação e importação, apoio à pequena e média empresa, redesconto do café, crédito cooperativo, serviços de consultoria, desenvolvimento tecnológico, imobilizações financeiras, reconstrução de imóveis, apoio à Previdência Social, capitalização de empresas, operações cinematográficas, pesquisa de recursos minerais e crédito agrícola em toda a sua expansão". Nesses programas empregam-se cerca de 800 bilhões, através das instituições de crédito oficiais e privadas, com dotações governamentais (Folha de São Paulo, 18 de maio de 1981, p. 7).

${ }^{25}$ Conforme dados do Banco do Brasil, em 1976 os "pequenos" estabelecimentos respondiam por cerca de $80 \%$ do número de contratos efetuados pelo Banco; participavam com menos de $20 \%$ do total de créditos concedidos e cerca de $80 \%$ das propriedades rurais não tinham acesso ao crédito.

${ }^{26}$ Os créditos concedidos pelo Banco do Brasil à agricultura brasileira evoluíram, no período entre 1966 e 1976 , em 2,23 vezes no tocante ao número de contratos e 71,2 vezes ao valor. Nesse mesmo período, os créditos à pecuária tiveram uma expansão de 3,31 vezes no número de contratos e de 79,26 vezes em relação ao valor. No período 1970-75, os créditos destinados à agropecuária pelo Banco do Brasil, que representavam 41,7\% dos empréstimos globais em 1970, evoluíram para 53,7\%, no final do período. Durante esses cinco anos, o crédito rural expandiu-se em 835\%, contra uma expansão de $476,5 \%$ para os demais créditos.
} 
1978 a expansão foi de 35,3\% e, em 1980, de 143,5\%. Cerca de 79,7\% desse crédito em 1976, 87,9\% em 1977 e 99,4\% em 1978 foram destinados à produção cabendo o restante à comercialização e melhoramentos (Banco do Brasil, 1977, p. 50; 1978, pp. 42-43).

Boa parte desses recursos têm como fonte o Banco Mundial, em especial o Banco Interamericano de Desenvolvimento, sendo repassados ao Banco do Brasil e bancos regionais para programas específicos. Esses empréstimos do Banco Mundial para a agropecuária brasileira, que começaram na década de 1960, expandiram-se na década de 1970. Entre 1967 e 1973, o Banco Mundial emprestou cerca de 66 milhões de dólares à pecuária brasileira (Banco Mundial, 1973, pp. 11-13). Já o BID, no período 1961-78, concedeu 2.911 .338 mil dólares ao Brasil, em projetos cujo total era de 23.112 .235 mil dólares. A agropecuária foi contemplada com 265.313 mil dólares em projetos, com um custo total de 745.863 mil dólares e mais 118.781 mil dólares em financiamentos às exportações. No tocante a "cooperação técnica e desenvolvimento rural", o Banco aprovou, em 1978, "uma operação não-reembolsável, em cruzeiros, no valor de 14,5 milhões de dólares, para um programa de assistência à agricultura de baixa renda no Brasil". Em relação ao crédito agrícola para pequenos e médios produtores, "em 1975, o Banco aprovou um empréstimo de 40 milhões de dólares para permitir ao Banco Central do Brasil a execução de um programa de crédito agrícola supervisionado, criado para aumentar a produtividade e as rendas de médios e pequenos agricultores, fortalecer as cooperativas existentes e estimular a formação de outras. Até meados de 1978, tinham sido aprovados cerca de 2.894 créditos individuais, dentre os quais 71 foram outorgados a cooperativas para melhorar o armazenamento de cereais, para refrigeração de carnes e laticínios e para instalações de comercialização de produção agrícola" (BID, 1979, pp. 48-50). Boa parte desses recursos foram repassados pelo Banco Central ao BRDE - Banco Regional de Desenvolvimento do Extremo Sul -, para o desenvolvimento e consolidação de produção de aves e suínos, através da integração contratual.

O aprofundamento da crise surgida em meados da década passada passou a influir gradualmente na política de crédito rural, em termos quantitativos e, principalmente, em seu redirecionamento no sentido de uma maior racionalização, ou seja, passou a haver uma maior busca da modernização da produção agropecuária, concomitantemente com a diminuição dos juros subsidiados (Avicultura Industrial, setembro de 1980, pp. 16-17). Mesmo assim, em 1980, o crédito rural equivalia ainda a cerca de $86 \%$ do produto líquido da agricultura.

De qualquer modo, se de um lado a elevação das taxas de juros e outras medidas de maior rigor na concessão de crédito, tendo em vista uma maior produtividade, pode dificultar o acesso de determinados segmentos da avicultura, de outro, isso não significa de imediato uma redução no 
montante dos financiamentos. ${ }^{27}$ Além disso, a restrição do crédito de comercialização às cooperativas não compromete a comercialização de produtos avícolas, visto que está a cargo das empresas processadoras, no caso da integração horizontal, que contam com outras fontes de financiamentos. No caso de integração vertical, por definição, não há comercialização entre produtor rural e empresa processadora.

Essa nova orientação do crédito rural, em especial a nova taxa de juros, provocou uma série de pressões por parte de "associações" vinculadas de alguma forma à produção agropecuária e cooperativas. O Governo justifica a nova política, fundamentalmente, em termos da necessidade de diminuir gradativamente os subsídios, elevar o preço da produção e uma melhor distribuição dos créditos aos produtores de menor porte. No caso do complexo avícola, a nova política levou a Associação Brasileira de Exportadores de Frangos e outras organizações a proporem mudanças específicas na regulamentação do crédito. Entre as principais, está a reivindicação de que a política de crédito considere as exportações brasileiras de frangos - que está dentro das metas do Governo e a especificidade das produções capital-intensivas, como a avicultura, suinocultura e fruticultura, nas quais os investimentos fixos têm maturação longa. Por isso, as associações exigem que, enquanto os investimentos não têm retorno, não seja cobrada correção monetária, finas apenas os juros. Outra proposta apresentada é que, para as atividades de alta densidade econômica e pequeno valor agregado, como a avicultura, o critério para classificação dos produtores em mini, pequeno e grande não seja o valor bruto da produção, mas o valor agregado (A Granja, janeiro de 1980, pp. 64-65). De qualquer modo, as reorientações na política de crédito rural, ao que tudo indica, não reduzem substancialmente o montante global de financiamentos, ao menos no tocante ao crédito para custeio. A avicultura conta ainda com as vantagens de explícita prioridade para a pecuária leve e para as exportações. Segundo declaração da direção do Banco do Brasil: "A avicultura deve merecer atenção especial pela sua crescente importância na pauta de exportações brasileiras: oitavo lugar entre os produtos básicos com a estimativa de receita da ordem de 240 milhões de dólares este ano" (Avicultura Industrial, fevereiro de 1981, p. 29).

Os financiamentos e subsídios, no entanto, não se restringem à produção agropecuária. Nesse sentido o complexo avícola também exemplifica a interdependência entre acumulação e intervenção do Estado. 0 caso do complexo avícola em Santa Catarina esclarece esse aspecto. Por

\footnotetext{
27 Segundo o responsável pelo setor de financiamentos agrícolas do Banco Itaú, essas mudanças podem provocar alterações na tomada do crédito pelos avicultores ("fazendo com que os mesmos passem a ser verdadeiros capitalistas"), na medida em que antes "os $15 \%$ (destinados ao crédito rural) eram disputados por qualquer produtor, grande ou pequeno, em suposta 'igualdade de condições', quando, na realidade as NPRs (Notas Promissórias Rurais) apresentadas para operações de desconto, dos grandes produtores, pela maior garantia oferecida por seus compradores, automaticamente os tornavam candidatos preferenciais aos empréstimos". Atualmente os "pequenos" e "médios" produtores teriam acesso garantido ao crédito (Avicultura Industrial, janeiro de 1981, p. 11).
} 
possuir uma avicultura mais desenvolvida e estruturada e porque em geral os agentes financeiros operam através de programas, existe nesse Estado uma maior disponibilidade de informações sobre o crédito à avicultura.

Tratando-se, porém, de uma avicultura integrada horizontalmente e por contrato em sua maioria, o crédito ao complexo avícola industrial e aos produtores de aves em boa medida se confundem, o que dificulta seu exame separadamente.

De qualquer modo, já em 1976 o Cepa-sc concluía que "o desenvolvimento da avicultura no Estado está alicerçado no amplo apoio que tem recebido do Crédito Rural. A rede bancária oficial, bem como os bancos particulares, têm destinado à avicultura os recursos necessários à sua aplicação e aperfeiçoamento tecnológico quer no setor industrial, quer a nível do criador, na aplicação e custeio de novas unidades produtoras" (Cepa-SC, 1976, p. 29). 0 entrelaçamento entre o capital financeiro oficial e as empresas privadas abrange inclusive a forma de acesso aos financiamentos. "Empresas particulares atuam na comercialização de insumos e na elaboração de projetos para obtenção de financiamentos destinados à implantação de novas unidades produtoras e/ou custeio de projetos em execução" (idem). ${ }^{28}$ No tocante ao crédito de investimento, o prazo para amortização conforme o banco, entre cinco e dez anos, e os agentes financeiros exigem para crédito ao produtor a hipoteca de um bem, além do aviário que está sendo financiado.

Em 1975, época do início do surto de crescimento, os agentes financeiros da avicultura catarinense foram: Banco do Brasil com quase 94 milhões de cruzeiros, representando cerca de 60,57\% do total, num total de 619 contratos; Banco do Estado de Santa Catarina, com 30,6\% do total de 149 contratos; o Banco Regional de Desenvolvimento do Extremo Sul, com 9,37\% do total. Conforme levantamentos do Cepa-SC nas regiões produtoras de aves, em 1975, o valor financiado para a avicultura nessas regiões atingiu 101,4 milhões de cruzeiros, com 630 planos de financiamentos aprovados. Em 1976 estima-se que houve um crescimento nos financiamentos superior a $40 \%$ em relação a 1975 (ibid., p. 31).

Já em 1978 o Banco de Desenvolvimento de Santa Catarina financiou a avicultura em cerca de 20 milhões e o Banco Nacional de Crédito Cooperativo destinou ao setor pecuário 93,5 milhões. O Banco do Estado de Santa Catarina, entre custeio e comercialização, aplicou mais de 333 milhões

\footnotetext{
${ }^{28}$ Conforme pesquisa, além do financiamento para o produtor, os frigoríficos têm exercido influência, ainda, na obtenção de crédito através do credenciamento junto ao Banco. Nos empréstimos para custeio, freqüentemente o Banco libera o financiamento diretamente ao frigorífico, após abonada a nota de suprimento pelo produtor. "O frigorífico quase sempre avaliza a operação de custeio do produtor. Os produtores integrados de aves têm apresentado dificuldades de pagamento das amortizações dos empréstimos bancários devido ao baixo preço pago pelo frango vivo. Entretanto, supõe-se que os produtores se mantêm nessa atividade imbuídos de um efeito monetário ilusório, sem saldos positivos e que lhes exige outras receitas para a sua manutenção ou, então, na expectativa de colher alguns resultados futuros após o pagamento da amortização dos equipamentos e instalações" (Cebrae/Ceag-SC, 1978, pp. 185-88).
} 
de cruzeiros. "O BRDE tem atendido à avicultura principalmente com recursos de seus programas Pesac e BID, dos quais mais de $20 \%$ destinados ao financiamento de projetos avícolas. Em que pese às restrições creditícias observadas nos últimos anos, o BRDE liberou à avicultura, a partir de 1975, verbas no valor aproximado de 335 milhões de cruzeiros" (Avicultura Industrial, outubro de 1979, p. 45). Nessa mesma época o BRDE esperava receber novos recursos da ordem de 200 milhões para financiamentos à avicultura catarinense.

O maior projeto de financiamento e subsídio oficial ao complexo avícola catarinense, no entanto, parece ser o promovido pelo Cebrae/Ceag-SC. Em 1972 foi criado pelo Governo Federal o Centro Brasileiro de Assistência Gerencial à Pequena e Média Empresa, regulamentando o apoio oficial a determinados setores industriais. Com base na regulamentação - se bem que não observando à risca a definição de "pequena e média" empresas, por se tratar quase exclusivamente de "grandes" - o Cebrae, em conjunto com o Ceag-SC - Centro de Assistência Gerencial de Santa Catarina, Codesul - Conselho de Desenvolvimento do Extremo Sul, SIC, BRDE e Procape, formularam um programa de financiamento à avicultura e suinocultura em Santa Catarina. ${ }^{29} \mathrm{O}$ objetivo básico do programa é "(...) a promoção do desenvolvimento da Indústria de Frigoríficos de Carnes de Suínos e Aves de Santa Catarina, com vistas à dinamização deste segmento industrial e à conquista de uma maior fatia de participação no mercado nacional e internacional" (Cebrae/CeagSC, 1977).

Foram selecionados para o programa de investimentos, ampliação e modernização, 13 frigoríficos de suínos e 10 de aves. Geralmente os de suínos e aves fazem parte da mesma empresa. "Foram excluídos apenas estabelecimentos de porte muito reduzido ou em perspectivas de cessação de atividades." As principais metas do programa são promover "(...) a adequação das plantas às normas higiênico-sanitárias vigentes no país e requeridas no mercado internacional; a modernização dos frigoríficos quanto a processos e equipamentos, visando à adaptação a estruturas produtivas compatíveis com um maior aproveitamento econômico da matéria-prima, além de objetivar a eliminação de pontos de estrangulamentos internos e o ajustamento de lay-outs inadequados; e a ampliação da produção, tendo por metas passar de 1.275 mil cabeças de suínos e 50.250 mil de

\footnotetext{
${ }^{29}$ Cabe notar que projetos como esse não são uma particularidade da avicultura catarinense, embora esta esteja sendo tomada como modelo. No Rio Grande do Sul, por exemplo, em 1976, por iniciativa do Governo Estadual, foi elaborado o Programa de Indústria de Carnes Suínas e Aves, também visando aumentar e melhorar a produção através da implantação de projetos integrados, melhoria técnica da indústria de transformação e assistência financeira (Sudesul) FEE, 1976. Nesse mesmo Estado, a partir do Segundo Plano Nacional de Desenvolvimento, foram selecionadas 92 atividades consideradas agroindustriais, para as quais se previam investimentos de 7,5 milhões de cruzeiros entre 1975 e 1979 (Sudesul, 1976). Para Minas Gerais, o BDMG elaborou plano semelhante em 1980, especificamente para a avicultura, tendo em vista em especial a ampliação e modernização da indústria de abate de aves, com previsão de investimento de 2.250 milhões de cruzeiros (BDMG, 1980).
} 
frangos, em 1975, para 2.257 mil de suínos e 102.450 mil de aves a serem abatidas em 1979" (ibid., p. 6).

Conjuntamente, "(...) são incluídas no programa as estimativas de investimentos necessários para a ampliação dos sistemas de fomento (integração horizontal) à produção de matéria-prima, propondo-se, como objetivos para 1979, a integração total da produção de aves, e 50\% da produção de suínos a serem abatidos naquele ano" (ibid.).

Esse programa de financiamentos prevê prazos de carência até o período de maturação dos investimentos produtivos, de acordo com as condições de cada empresa. No caso de haver mais interessados que recursos ou, no caso de restrições, as prioridades são definidas conforme a acessibilidade à matéria-prima, eficiência econômico-financeira e as potencialidades técnicas da empresa. Quanto à origem dos recursos financeiros, o BRDE, na qualidade de agente financeiro, repassa os recursos das principais instituições oficiais de crédito, particularmente do Banco Nacional de Desenvolvimento Econômico - BNDE e Banco Central do Brasil - Bacem.

\subsubsection{OS PREÇOS ADMINISTRATIVOS}

A intervenção do Estado na formação direta de preços relativamente ao complexo avícola é intensa, principalmente no caso dos preços dos produtos fanais. Em relação ao preço das matériasprimas originárias da produção agropecuária, as próprias empresas o administram de modo direto, especialmente quando se trata de integração por contrato. A atuação estatal, nesse caso, torna-se explícita e mais intensa nas situações de crises. Nas relações de compra e venda entre produtor integrado e empresa integradora, por definição, não existe mercado opcional e, portanto, os preços são estabelecidos "administrativamente". No caso dos produtores de aves integrados sem contrato, há a concorrência entre as diversas empresas compradoras pela matéria-prima, como sucede particularmente em Minas. Mas, nesse caso, as empresas tomam em geral como parâmetro os preços dos produtores integrados por contrato. Além disso, a centralização progressiva das indústrias - com a conseqüente divisão de áreas - e a relativa imobilidade do produtor rural reduzem suas opções de mercado.

Quanto ao estabelecimento dos preços dos insumos de origem industrial para o complexo avícola, a presença do Estado é constante, especialmente na criação das condições de produção, mais do que propriamente pela taxação dos preços. Por outro lado, a intervenção na formação e negociação de preços sempre é mediada por uma ou mais associações de classe ou grupos de pressão. Tanto o direcionamento da intervenção quanto sua intensidade dependem da atuação e das forças desses grupos. 
O condicionamento da formação de preços ao jogo das associações de classe abrange também as relações de compra e venda entre produtores rurais e empresas processadoras, se bem que em outras condições sociais. Nesse caso, entram em jogo especialmente as associações de criadores, entre outras, que conforme o caso, podem organizar um razoável grau de pressão. Um dos mecanismos básicos de intervenção do Estado, nessas condições, é o estabelecimento de preços mínimos, elaborados a partir de cálculos oficiais e sempre "negociados" com os agentes envolvidos. O preço do frango vivo foi incluído na política de preços mínimos através dos financiamentos dos EGF (Empréstimos do Governo Federal) no final de 1979. Foi estabelecido ainda pelo Conselho Monetário Nacional que a fixação do preço mínimo para o frango vivo é alterada para cada dois meses conforme o preço da ração (Avicultura Industrial, novembro de 1979, p. 4). ${ }^{30}$

No condicionamento e formação de preços dos diversos componentes do complexo avícola, como referimos antes, entram em jogo as associações dos diversos blocos de capital e, no preço dos produtos finais para o mercado interno, as políticas de abastecimento e barateamento dos produtos alimentícios básicos. A partir de maio de 1976, a Sunab passou a controlar os preços da carne de aves. Esse órgão, vinculado ao Ministério da Fazenda, é encarregado das vendas, das exportações e importações etc. A Cobal atua como reguladora de mercado dos produtos alimentícios essenciais, podendo distribuir através de uma rede própria de lojas. Além disso, existem órgãos de poder decisório, como as Secretarias de Indústria e Comércio da Agricultura etc., a nível estadual, e o Conselho Interministerial de Preços, Secretaria Especial de Abastecimento e Preços etc., a nível federal, para onde convergem as pressões dos diversos grupos no sentido de condicionar a formação de preços. A intervenção desses órgãos pode ser direta, por exemplo, através de tabelamentos, ou pode se dar através de concessão ou retirada de subsídios, favorecimento fiscal, política de importação/exportação, formação de estoques reguladores etc. ${ }^{31}$

\footnotetext{
${ }^{30}$ Geralmente, as pressões dos criadores de aves, integrados ou não, são dirigidas contra a alta do preço dos insumos e a falta de um preço mínimo que cubra essa alta.

${ }^{31}$ Por exemplo, em 1981, a Cobal lançou em Porto Alegre seu programa "Fraão ng da Economia" através de sua "Rede Somar de Abastecimento". Para tanto foi assinado uni contrato entre a Cobal e a Avipal, maior empresa produtora de carne de aves no Rio Grande do Sul. Ainda que com contrapressões de setores específicos, como os vinculados à distribuição, gestiona-se a ampliação de programas desse tipo. Aos interesses contrariados, o presidente da Cobal tranqüiliza: "Para as classes produtoras e fornecedoras, quem sabe este seja uni bom investimento a médio e longo prazos. Pois, fornecendo outros tipos de carne a preços realmente razoáveis para a maioria da população, famílias que não consumiam este produto, ou que faziam pouco, poderão fazer com mais freqüência, modificando o tão famigerado hábito alimentar. Ou ainda, através de programas permanentes, planejar uma possível regularização do mercado em termos de oferta e procura." A organização que mais estava gestionando para distribuir através da Cobal em 1980 era a Apa. A proposta era que a Cobal assumisse a transação e as empresas distribuíssem em seu nome, até que a "empresa já se acostumou e sente que não há mais risco de fornecimento. A coisa então segue por si só", segundo o presidente da Cobal (Avicultura Industrial, julho de 1980, pp. 12-15). Nessa mesma época, era proposta pelo Sindirações a criação de um "banco frigorífico" (Frangobrás) para absorver os excedentes de carne de frango no mercado, a fim de que esses excedentes não rebaixassem os preços e colocação "dessa carne nas situações em que sua utilização seria compulsória, como nos programas governamentais de alimentos e dentro das Forças Armadas"; campanhas publicitárias etc. (Dirigente Rural, janeiro de 1980, p. 20).
} 
As formas mais usuais de intervenção governamental no preço de carne de frango e ovos é o tabelamento direto e o "acordo de cavalheiros", que consiste numa espécie de pacto entre a burocracia governamental e representantes dos setores envolvidos, no sentido de manter um determinado preço em troca de algumas concessões por parte do Estado. Como uni dos elementos desses acordos ou tabelamentos é a tentativa por parte do Estado de não permitir uma elevação brusca dos produtos básicos de consumo, as associações dos representantes dos blocos de capital atingidos continuam a pressionar na busca de outras concessões. Algumas vezes esses acordos fracassam pelas pressões ou rompimentos por parte de setores específicos (Avicultura Industrial, julho de 1980, p. 20).

De qualquer modo, existe um aspecto básico de todo o comportamento do conjunto de forças que atuam na formação e estabelecimento de preços que distingue os produtores integrados e representantes das diversas esferas do capital. Os primeiros, em geral, pressionam por um melhor preço mínimo, quase sempre em relação aos preços dos insumos, ao passo que os representantes do grande capital, como frigoríficos e fábricas de rações, atuam no sentido de que não sejam tabelados os preços dos produtos finais, mas que o Governo crie condições de produção e aumento de consumo, via de regra em nome da "lei de oferta e procura", que deveria funcionar livremente. É nesse sentido que uma das estratégias básicas da indústria de transformação e de rações é somente aceitar interferências governamentais na medida em que sejam concedidas outras vantagens nas condições de produção e realização. Assim, em compensação às intervenções que possam restringir os lucros, como tabelamento dos preços finais, recriam-se mecanismos que modifiquem as condições de produção e realização. ${ }^{32}$

$\mathrm{Na}$ produção de frangos de corte e na formação de preços de produtos finais a atuação do Estado é menos intensa, pela relativa competitividade desse tipo de carne em relação às demais, pelo menos nos últimos anos, e pela possibilidade de exportações apoiadas pelas políticas governamentais. Ao contrário, na avicultura de produção de ovos, por possuir menores condições internacionais para exportação e por ser um produto alimentício básico, a interferência governamental no estabelecimento do preço ao consumidor tem sido mais intensa, o que provoca

\footnotetext{
${ }^{32}$ Um dos casos piais ilustrativos de criação de condições de produção e realização para o capital vinculado à produção de carnes é o apoio do Estado no setor de armazenamento, ilustrativo também do intercruzaniento entre capital privado e estatal. Hoje, unia câmara de 40.0003 de capacidade (7 mil toneladas de frangos ou 10t de carne bovina) exige uni investimento acima de 320 milhões de cruzeiros. E o retorno do capital aplicado é muito lento. Porém, havia necessidade de se formar unia infra-estrutura para o futuro, em termos de guarda de produtos da agricultura. E o Governo financiou a iniciativa privada, financiando a construção de grarides armazéns frigoríficos (empresa privada de prestação de serviço). Obviamente, o Governo deixou de se preocupar com o armazenamento a frio, mas a responsabilidade foi dividida com aqueles que realmente desejavam melhorar as condições de estocagem de alimentos e lucrar com essa atividade (Atualidades Agropecuárias, julho de 1980, p. 10).
} 
reações por parte dos setores atingidos. Nesse caso, porém, a participação da indústria de transformação é mínima, o que contribui para o enfraquecimento das pressões.

Uma das maneiras de compensar esses tabelamentos está no apoio governamental às associações vinculadas ao complexo avícola, no sentido de ampliar o mercado interno. Essas campanhas foram intensificadas inicialmente no Paraná e em São Paulo pelas associações vinculadas à avicultura e apoiadas pelas Secretarias de Estado e visam aumentar a venda no mercado interno através de mudança nos hábitos de consumo (A Granja, março de 1981, p. 22). Outra forma utilizada para ampliar o mercado interno é, por exemplo, o estímulo por parte do Governo ao consumo institucional.

Ainda que indiretamente, o Estado condiciona a formação dos preços através da regulamentação e fiscalização de normas higiênico-sanitárias. Essa normalização implica a adoção de um determinado patamar e padronização da produção e, portanto, de custos da produção e pode servir como reorientação do mercado consumidor, além de eliminar empresas sem condições de cumpri-la. Por isso, qualquer alteração na regulamentação em vigor, em geral, provoca uma série de atritos entre agentes envolvidos. Para se ter uma idéia da heterogeneidade da indústria processadora em relação às normas higiênico-sanitárias, pode-se tomar, por exemplo, o caso de São Paulo, onde, segundo o diretor do Dipoa: "Quanto às indústrias de abate de carne de aves no Estado de São Paulo, recebemos no Dipoa um apoio fantástico em relação às medidas aplicadas aos estabelecimentos que não tenham condições de abate, enquadrados na referida lei. Existe uni plano de afastamento e gradual substituição desses estabelecimentos (...). Atualmente, são apenas dez abatedouros de carne de aves que possuem instalada a federalização, e mais dez em via de serem federalizados. De um total de quase 500 estabelecimentos que levantamos com uma pesquisa, apenas 16 abatedouros em São Paulo foram considerados recuperáveis pelo Dipoa para receberem a inspeção federal. Portanto, podemos verificar que a esmagadora maioria receberá ordem de fechamento" (A Granja, janeiro de 1975, pp. 21-22).

Em 1978, o Ministério da Agricultura, através da Portaria 974/78, procurou traçar normas para fiscalização dos estabelecimentos avícolas. Essas normas contrariavam em alguns aspectos os interesses das empresas do setor e, após muitas gestões e pressões da UBA e outras associações junto ao Ministério e à Secretaria Nacional de Defesa Animal, foram alterados os itens em desacordo (Avicultura Industrial, outubro de 1979, pp. 24-25).

Em síntese, a intervenção estatal na formação dos preços em relação ao complexo avícola é intensa, ainda que em boa medida seja indireta e não atue apenas em relação aos preços em si, mas na formação das condições de produção e mercado. 


\subsubsection{A POLÍTICA DE EXPORTAÇÃO}

A política de exportação, tanto em relação ao complexo avícola quanto às demais linhas de produção, é complementar aos demais mecanismos de intervenção estatal, visto que esses mecanismos são multilaterais e interdependentes, embora atinjam assimetricamente os diversos grupos de interesses. Para o complexo avícola, especificamente, a política de exportação constituise num esteio básico de atuação do Estado na formação de mercados e, portanto, nas condições sociais da lucratividade.

A partir de 1964, e particularmente no período pós-1967, a política de exportação passou a ser um dos complementos básicos dos incentivos à produção agropecuária e agroindustrial. De "acordo com a política governamental, passaram a ter prioridade os empréstimos destinados à implantação de projetos integrados, à utilização de sementes selecionadas, adubação e correção dos solos, emprego de maquinaria enfim, ao aproveitamento imediato de todos os recursos que a moderna tecnologia oferece, com a finalidade de aumentar o rendimento unitário das lavouras" (Banco do Brasil, 1975, p. 5). Essa política de incentivo ao aumento da produtividade está diretamente vinculada aos incentivos às exportações e à própria internacionalização da economia brasileira. $^{33}$

A política de incentivos às exportações provocou a reestruturação dos organismos oficiais e seu reaparelhamento, passando a ser instalada ou modificada uma série de mecanismos e subsídios. ${ }^{34} \mathrm{Na}$ reorganização da Carteira de Comércio Exterior - Cacex, do Banco do Brasil, foram criados os Comitês de Exportação, entre os quais o Comitê de Carnes e Derivados. "Esses comitês, sob a presidência da Cacex, reúnem representantes do Poder Público - federal e estadual -, e das associações de classes produtoras, industriais e exportadoras" (Banco do Brasil, 1975, p. 20).

Um dos aspectos básicos da política brasileira de exportações, de importância particular para o complexo avícola, é a política de incentivo às exportações de produtos manufaturados ou beneficiados, juntamente com o apoio ao capital externo e ao equilíbrio do balanço de pagamentos. É objetivo explícito, desde a década passada, a "diversificação da pauta de exportações, em especial ênfase na expansão de duas categorias capazes de competir com a posição do café: a de produtos

\footnotetext{
${ }^{33}$ Sobre os conflitos e limites das políticas agrícolas, especialmente a partir de 1980, que terão de dar conta de metas conflitantes corno o aumento da produção de alimentos, das exportações e energética (álcool), ver Homem de Melo, 1980.

${ }^{34}$ Em 1979, por exemplo, as operações do Banco do Brasil "(...) de financiamento à exportação acusaram uni saldo de 72,9 bilhões de cruzeiros" (Banco do Brasil, 1980, p. 35). Em 1980, o volume de subsídios implícitos nas exportações passou de 36 milhões de cruzeiros e em 1981 elevou-se para cerca de 158 milhões, ou seja, 341,4"4,. Além disso, há o crédito rural subsidiado que se destina à produção agropecuária para exportação, equivalente a 203 bilhões e 100 milhões de subsídios, implícitos nos empréstimos de 1980, e 455 bilhões e 800 milhões de cruzeiros em 1981, com um acréscimo de 124,414 (Follia da Tarde, 19 de junho, 1981, p. 33).
} 
manufaturados e a de minérios (produtos agrícolas não-tradicionais)" (Ipea, 1974, p. 19).

A expansão da produção e exportação de produtos avícolas, particularmente de frangos, se inscreve nesse processo de internacionalização da economia brasileira, com urna forte participação dos aparelhos estatais na criação das condições sociais de produção e realização, onde intervém o mercado externo. Por outro lado, o complexo avícola se vincula ao mercado externo através da importação de capitais e insumos sofisticados, em especial através dos setores de insumos químicoveterinários e genéticos, o que de certa forma influencia a política de exportação/importação.

De qualquer modo, como resultado de determinadas condições de produção, tais como moderna tecnologia, mão-de-obra e renda fundiária a baixo preço, custo, internacionalização da economia brasileira e apoio às políticas de exportação, os produtos avícolas tiveram um acelerado incremento nas exportações. No tocante ao mercado interno, a expansão do consumo está vinculada às dificuldades de abastecimento de carne bovina e à capacidade de resposta da avicultura, por ser uma produção de ciclo curto e que não requer grandes quantidades de área de terra nem está sujeita aos mesmos riscos, se bem que conte com um custo relativo de produção elevado.

Entre 1978 e 1980, a avicultura de corte no Brasil cresceu em tomo de 21,2\% ao ano. Estima-se que em 1980 houve um crescimento superior a 25\%. Nesse ano, foram exportadas cerca de 140 mil toneladas através da Unef e de tradings estatais e particulares. De acordo com a Cacex, as exportações de carne de frango tiveram um crescimento de $153 \%$ em 1980, representando um total de 155 milhões de dólares de divisas, esperando-se o mesmo crescimento em 1981. Nesse mesmo ano, segundo a Abef, do total estimado de 1.500 mil toneladas a serem produzidas, cerca de 260 mil serão exportadas. Desse modo, a participação brasileira no mercado externo aumentará de 13\% para 20\%, num total de 325 milhões de dólares, contra 81 milhões de dólares em 1979. Isso preocupa a Abef, na medida em que o Brasil desloca os principais países exportadores de frangos (EUA, Holanda e Alemanha), que são também os fornecedores de material genético (A Granja, janeiro de 1981, p. 12).

\subsubsection{PESQUISA E ASSISTÊNCIA TÉCNICA}

A pesquisa e assistência técnica são interdependentes, estão vinculadas ao capital externo, às empresas integradoras, à intervenção estatal e se constituem num dos instrumentos básicos do aumento da produtividade e reorganização da produção. Contudo, a participação desses elementos, em especial o grande capital e o Estado, varia na medida em que se trata de pesquisa ou assistência técnica e, inclusive, no decorrer do processo de consolidação do complexo avícola.

A pesquisa e produção tecnológica, particularmente as relacionadas a material genético e 
insumos químico-veterinários sofisticados, estão estreitamente ligadas ao grande capital internacional, sendo um dos elos básicos da internacionalização do complexo avícola, como foi visto anteriormente. A pesquisa de controle genético está a cargo quase exclusivamente dos maiores centros internacionais do capital e é importada juntamente com boa parte da tecnologia de manejo e de organização da produção. Já a tecnologia sofisticada de produção de insumos químicoveterinários, embora seja também produzida essencialmente nos centros tecnológicos mundiais, em sua maior parte é produzida pelas empresas instaladas no Brasil, como foi visto no primeiro capítulo. Por ser um setor industrial já consolidado internamente e ao mesmo tempo altamente internacionalizado, a transferência de tecnologia nesse caso é feita através das relações entre empresas filiais com as matrizes. Em outros termos, a transferência de tecnologia sofisticada se dá juntamente com a transferência de capitais e no relacionamento entre a empresa instalada e a matriz.

Desse modo, a atuação do Estado nesse setor é essencialmente subsidiária e complementar. Sua atuação, no entanto, amplia-se em conjunto com as empresas integradoras, pela própria dinâmica do complexo avícola e pela importância que possui no conjunto das políticas oficiais. Mesmo que tenda a se intensificar, a ação do Estado se caracteriza por centrar-se na assistência técnica, ou seja, no acompanhamento da aplicação tecnológica e, num segundo plano, na adaptação da tecnologia já desenvolvida, atingindo apenas tangencialmente a pesquisa mais sofisticada.

Ainda que complementar, a atuação do Estado tendeu a se intensificar a partir dos anos 1970. Em boa parte em virtude da insuficiência da expansão horizontal da agropecuária para a fronteira agrícola para dar conta do abastecimento interno e exportações, e da pressão do moderno capital vinculado à agropecuária no sentido de aumentar a utilização de insumos modernos e elevação da produtividade física. Houve simultaneamente um reaparelhamento dos organismos oficiais de assistência técnica, maior apoio financeiro oficial e definição de unia política claramente voltada à adaptação tecnológica e abandono de qualquer pretensão de criação tecnológica. Conforme o Presidente da Embrapa, de 1972 a 1980 o Governo multiplicou por 30 a quantia investida em pesquisa. Contudo, sua função básica "(...) não é contribuir para novas teorias científicas nem criar modelos. Seu objetivo é utilizar o conhecimento científico existente para gerar conhecimento tecnológico." Conforme seus planos, isso seria feito em colaboração mútua com a pesquisa privada. Nesse sentido, a produção de aves e suínos seria o exemplo a ser seguido (Avicultura Industrial, agosto de 1980, pp. 17-19). Essa estratégia de adaptação tecnológica em colaboração com a pesquisa privada se dá em boa medida pela estreita vinculação de organismos oficiais, como a Embrapa, aos centros internacionais de pesquisa. Essa interação é feita através de importações de resultados de pesquisas e experimentos, intercâmbio de pessoal técnico, estudos etc. (Embrapa, 1979-80). 
Na década de 1970 foi quando os investimentos oficiais em pesquisa e assistência técnica mais se acentuaram. No tocante à Embrapa, no período 1974-78, a participação direta em projetos evoluiu de 552 para 2.557, além da contribuição na implantação e consolidação,

de 11 centros nacionais de pesquisas de recursos (genética, cerrados, trópico úmido, trópico semi-árido), do Centro de Tecnologia de Alimentos e dos serviços nacionais (sementes básicas e solos), além de 17 unidades de pesquisa de âmbito estadual. A ação coordenadora da Embrapa se fez sentir no trabalho articulado com nove empresas estaduais de pesquisa, já instaladas, e sete programas integrados com secretarias de agricultura (Suplan, 1979, p. 23).

Ao mesmo tempo foi ampliado o número de municípios atendidos pela assistência técnica da Embrapa, de 2.340 em 1973 a 3.100 em 1978, aumentando seu quadro de técnicos de 5.197 para 9.642 e elevando o número de produtores atingidos de 240 mil para 820 mil, no mesmo período. O orçamento do Ministério da Agricultura, nesse período, cresceu em 99\%. Os organismos que tiveram maior crescimento nas aplicações foram a Embrapa (265\%), Embrater (203\%) e Cibrazem (210\%), com receitas provindas de recursos orçamentários e de programas especiais (ibid. ).

Em 1974, com a atenção voltada especialmente para a difusão de tecnologia em articulação com a Embrater, a Embrapa definiu 700 sistemas de produção para vários produtos de criações, para as diferentes regiões brasileiras. Desde então, foram realizadas reuniões que contavam com a participação de 800 pesquisadores, 1.000 agentes de extensão e 1.200 produtores selecionados. Quanto à realização de pesquisas específicas, foram feitas algumas para a produção de arroz, bovinos, feijão, hortaliças, mandioca, milho, seringueira, caprinos e ovinos, soja, sorgo e trigo.

Para a extensão rural foi criada em 1975 uma nova empresa pública, a Embrater, que substituiu a Abcar. Já para o esforço concentrado, "significando ação seletiva, segundo prioridades que direcionam todos os programas e projetos do sistema" e sua vinculação aos objetivos governamentais, foi criado o Sistema Brasileiro de Assistência Técnica e Extensão Rural Sibrater, em 1975, que atua articuladamente com a Embrater. O Sibrater, "através de empresas vinculadas, vem concentrando suas ações em produtores associados às prioridades estabelecidas pela programação setorial da agricultura; as ações diretas se concentram em determinadas zonas, de modo a permitir o caráter maciço e em profundidade da assistência técnica; as ações obedecem a critérios claros e objetivos para estratificação dos produtos assistidos, diferenciando-os em público de média e alta renda e público de baixa renda, aos quais se procura aplicar modelos de ação específicos e adaptados" (ibid.). Outra estratégia do Sibrater, Embrapa e Embrater é a utilização do crédito rural orientado, em convênios com agentes financeiros públicos e privados, como instrumento de transferência de tecnologia ao produtor rural. De 57 mil planos elaborados em 1974, esse número evoluiu para 135 mil em 1978, equivalente a 13.103 milhões de cruzeiros, com um 
crescimento de $355 \%$ no período. No sentido da utilização do crédito rural como transferidor de tecnologia existe pressão também dos setores financeiros. Freqüentemente, os bancos e suas associações enfatizam a necessidade de uma vinculação mais estreita entre o crédito rural e a adoção de uma "moderna tecnologia" (A Granja, agosto de 1977, pp. 29-30).

No caso do complexo avícola industrial também a assistência técnica oficial é complementar à assistência técnica privada. Ela é por definição de natureza seletiva. Mas, na avicultura industrial e formas de produção semelhantes, é seu próprio caráter de produção agropecuária integrada e comandada pelo grande capital que desloca a assistência técnica oficial no tocante à pesquisa e assistência técnica. Ela é exercida especialmente através do financiamento e da criação das condições de produção e realização e, portanto, também do desenvolvimento tecnológico pelo capital integrador.

O próprio crescimento da assistência técnica oficial e do próprio complexo avícola tende a criar ou reforçar organismos regionais que aprofundam a pesquisa e assistência técnica, complementares à ação direta do capital integrador. Assim, por exemplo, em Florianópolis, em 1980, em reunião entre representantes do Ministério da Agricultura, universidades, instituições estaduais de pesquisa, indústrias de carnes e rações, Abef, extensão rural, CNPSA (Centro Nacional de Pesquisa de Suínos e Aves/Embrapa) e produtores, "foi elaborado um documento básico, visando identificar os principais problemas a serem estudados e respectivas prioridades. Segundo o Programa Nacional de Pesquisa em Aves, existem oito áreas prioritárias para pesquisa: melhoramento, sanidade, nutrição, fisiologia, manejo, tecnologia e comercialização de produtos avícolas, economia e sistema de produção". Para esse órgão, a avicultura é o setor agropecuário de "melhor aporte tecnológico e maior potencial produtivo, a única em condições de responder, a curto prazo, a qualquer estímulo de demanda de proteínas". De qualquer maneira, o PNP/Aves acredita que são favoráveis as tendências nos mercados interno e externo. Destaca que se tornou necessária a conjugação dos esforços dos diversos órgãos atuantes nas áreas de pesquisa, extensão e crédito, entre outros, visando prover a exploração das condições necessárias ao seu desenvolvimento.

As metas gerais do programa são: aumentar a produção, preferencialmente via elevação da produtividade; melhorar a qualidade do produto pela classificação, armazenagem e transporte adequado, através de equipamentos e máquinas específicas; e aumentar a receita dos produtores através da diminuição dos custos de produção pelo melhor manejo e controle gerencial. (...) Já os objetivos da pesquisa incluem: identificar e avaliar física e economicamente os sistemas de produção de aves existentes nas diferentes regiões brasileiras; elaborar, implantar e testar sistemas de produção de aves no próprio CNPSA ou em propriedades particulares; desenvolver estudos sobre problemas considerados limitantes ao desenvolvimento da avicultura. A médio e longo prazos, pretende-se obter linhagens comerciais de aves para postura e corte; determinação da prevalência e distribuição das principais doenças das aves no Brasil e estudo de métodos de profilaxia e controle; avaliação química e biológica dos alimentos e dos oxigênios nutricionais (...) 
etc. (Avicultura Industrial, dezembro de 1980, pp.52-53).

A pesquisa referente à avicultura hoje restringe-se basicamente à adaptação tecnológica de manejo e nutrição. Essas pesquisas estão a cargo de universidades e centros de pesquisa. A médio prazo a Embrapa pretende desenvolver pesquisas sobre genética (Embrapa, 1981).

O Centro Nacional de Pesquisa foi criado por ação governamental, por solicitação das associações de criadores em 1980, em Santa Catarina. Nesse mesmo ano entrou em funcionamento também o Instituto Nacional de Defesa Animal, visando dar assistência técnica à avicultura e a todo o setor de produção animal (A Granja, outubro de 1978, p. 55). Linhas de produção como a avicultura industrial, comandada econômica e tecnicamente pelo grande capital e complementada pela ação do Estado, tendem a atingir um grau de desenvolvimento tecnológico e de produtividade do trabalho semelhante aos mais altos índices internacionais. A assistência técnica intensa e direta e a adoção de patamares técnicos mais elevados, com garantia de recursos financeiros, resultam, por sua vez, na reorganização da produção e resseleção dos produtores.

\subsection{ASSOCIATIVISMO, REPRESENTAÇÃO E EXERCÍCIO DO PODER}

Guardando-se as proporções e especificidades, a representação e exercício do poder com relação a um setor como a avicultura industrial é análoga ao do conjunto do grande capital em geral e aos blocos de capital hegemônico. As principais especificidades são decorrentes da vinculação da avicultura à agropecuária e, portanto, das peculiaridades das formas de transformação social nesse setor, por exemplo, das formas de integração. O fato de o complexo avícola relacionar-se à produção agropecuária acrescenta-lhe determinadas particularidades no exercício do poder, especialmente quando se trata de integração horizontal. Isso porque esse tipo de integração pressupõe a subordinação e seleção do campesinato a ser integrado e, para tanto, envolve de maneira mais direta e intensa mecanismos de controle "extra-econômicos".

Para exemplificar a analogia entre as formas de exercício do poder entre blocos do grande capital e o complexo avícola industrial, pode-se contrapor a Fiesp às associações "vinculadas à avicultura descritas a seguir". Segundo seu presidente, ao falar para representantes do Estado-Maior das Forças Armadas em 1981, a Fiesp

está permanentemente imobilizada, através do diálogo e da firme tomada de posições com relação a todos os assuntos que dizem respeito à Nação. Por isso (...) a Fiesp considera-se legítima interlocutora do Governo, ao representar e defender a empresa privada do setor industrial, em todos os seus níveis. (...) Enquanto empresários, somos protagonistas privilegiados da emancipação nacional. Queremos, portanto, através da Fiesp, ser consultados antes das tomadas de posições que direta ou indiretamente possam afetar o setor industrial e toda sociedade (Jornal do Comércio, 13 de maio de 1981, p.9). 
A exemplo do capital representado pela Fiesp, os diversos ramos que constituem o complexo avícola industrial articulam-se e se entrelaçam corri os aparelhos e instâncias do Estado. Ao se entrelaçarem na busca da racionalização e orientação da acumulação, buscam igualmente a realização dos interesses gerais, isto é, a viabilização político-institucional e ideológica dessa acumulação.

É por isso que é praticamente impossível a apreensão de qualquer política específica para o complexo avícola corno crédito, subsídios, política de exportação, administração de preços, em suas razões mais profundas, sem se fazer referência à rede de "associações" que medeiam os diversos interesses específicos dos diferentes ramos e blocos de capital e as instâncias decisórias do Estado. Ainda que essas "associações" se diferenciem quanto à maior ou menor ênfase em um ou outro aspecto em seus objetivos imediatos, a atuação no sentido da criação das condições sociais da acumulação num setor ou ramo específico não está dissociada da criação das condições políticoinstitucionais para a reprodução global do padrão de acumulação. De qualquer maneira, as relações entre os diversos componentes do complexo avícola industrial e o Estado são mediadas por uma vasta e complexa rede de associações e órgãos públicos que atuam nos mais diversos níveis. A seguir analisaremos as principais associações envolvidas no complexo avícola industrial, suas vinculações com organismos oficiais e algumas de suas especificidades ou campo básico de atuação.

\subsubsection{ASSOCIATIVISMO DO CAPITAL}

A nível nacional, uma das principais organizações que articulam os interesses vinculados à avicultura industrial é a UBA, União Brasileira de Avicultura. Foi fundada em 1963, sendo, portanto, relativamente recente, a exemplo da maior parte das associações ligadas à avicultura industrial. Além de atuar a nível nacional, a UBA se propõe como uma organização "representativa" de todos os setores e ramos abarcados pelo complexo avícola industrial. Sua Diretoria Setorial é composta pelos setores de produção de ovos, produção de frangos de corte, produção de matrizes, produção de pintos de um dia, abatedouros e frigoríficos, cooperativas, equipamentos veterinários, rações, comércio de produtos avícolas, técnico e de exportação.

Evidentemente, não precisa ser enfatizado seu caráter corporativo. ${ }^{35}$

\footnotetext{
35 O'Donnell define o corporativismo correspondente ao Estado burocrático autoritário como sendo "bifronte" e "segmentário". I "bifronte" por conter simultaneamente o componente "estatizante" e "privatista". O componente "estatizante" "(...) consiste na 'conquista' por parte do Estado, e conseqüente subordinação a este, de organizações da sociedade civil. O outro é 'privatista', na medida em que consiste, pelo contrário, na abertura de áreas institucionais do próprio Estado à representação de interesses organizados da sociedade civil". "Além de bifronte, o corporativismo é 'segmentário'; seu funcionamento real e seus impactos diferem sistematicamente segundo clivagens determinadas em grande medida pela classe social." (...)
} 
Apenas para destacar, podem-se tomar, por exemplo, os setores de produção de ovos e produção de frango de corte e cooperativas. A avicultura industrial no Brasil está organizada fundamentalmente sob a forma de integração horizontal e, portanto, com a produção agropecuária a cargo do campesinato integrado, especialmente no Sul. Sem falar no caráter seletivo e de subordinação à empresa integradora que essa integração significa, os produtores camponeses "canalizam" seus interesses juntamente com o mesmo capital que os subordina. Poder-se-ia pensar que, por se tratar de camponeses e, portanto, de trabalhadores rurais, os produtores integrados teriam outros canais de expressão de seus interesses. Contudo, por força do corporativismo da própria legislação sindical, como mostramos mais adiante, o meio de representação política efetiva desses camponeses se restringe a organizações tipo UBA. Além da legislação e estruturação corporativista que caracterizam os sindicatos, os mesmos se regem pela mesma lógica e "racionalidade" que as organizações "empresariais", ou seja, estritamente dentro da dinâmica da acumulação, por força de sua própria estruturação. Essa forma de representação de interesses como a da UBA é complementar, no caso da integração horizontal, à ação da própria empresa integradora, visto que esta passa a efetivar e, concretamente, a ser "representante" dos interesses dos integrados, enquanto empresa, ou através das "associações de criadores", de forma análoga ao que acontece com o "cooperativismo empresarial" formado em boa medida por camponeses (Coradini e Fredericq, 1982).

Outro aspecto que a composição da Diretoria Setorial da UBA evidencia é o intercruzamento entre associações de classe patronais. ${ }^{36}$ Praticamente todos os setores representados na UBA compõem outras associações, de caráter mais específico ou intersetorial, algumas das quais alinhamos a seguir. Quase sempre um mesmo representante de um determinado ramo participa de uma série de outras associações empresariais. Tendo como objetivo permanente a filiação de outras

\footnotetext{
"O caráter bifronte e segmentário desse corporativismo implica que o conteúdo principal da vinculação mediante seu componente estatizante seja o de controle sobre o setor popular. (...) Por outro lado, um dos componentes do corporativismo privatizante é o da representação de interesses ante o Estado (sobretudo devido, entre outras razões, ao viés introduzido pelo componente estatizante) das classes e setores dominantes da sociedade civil. Mas também existe nesse plano uni componente de mútuo controle, que pode ser visualizado em complexas interpenetrações entre esses setores e o Estado BA" (O'Donnell, 1976, pp. 3-4).

No caso em questão trata-se fundamentalmente de organizações civis e portanto de corporativismo "privatista". Porém, ao executarem políticas conjuntamente com órgãos públicos, através, por exemplo, de "grupos de trabalho", essas associações "trazem" componentes estatais para dentro de si através do entrecruzamento.

Cabe enfatizar o caráter "segmentário", na medida em que, numa estrutura de representação de interesses como a que está em questão, efetivamente todas as classes e agentes sociais envolvidos com o complexo avícola industrial, ao terem seus interesses mediados pelas "associações" empresariais, apresentam-se exclusivamente enquanto "empresários".

${ }^{36}$ Conforme o artigo segundo de seu estatuto, a "UBA não tem qualquer finalidade comercial ou fins lucrativos, sendo seu objetivo colaborar para o desenvolvimento da avicultura nacional, através da união e do fortalecimento de todos os setores, entidades, empresas e pessoas ligadas à produção, à industrialização, à comercialização, ao ensino, à pesquisa e divulgação". UBA (s/d)
} 
associações, como a Apinco (Associação dos Produtores de Pinto de Corte), Unac (União dos Avicultores de Corte) e as associações de caráter regional e/ou atuação conjunta, a UBA aumenta na prática as tensões internas, pela contraposição de interesses imediatos específicos (Realidade Agroavtcola, maio de 1980, p. 29).

Mas o entrelaçamento que mais diretamente interessa aqui é com os organismos oficiais. Estatutariamente, compete à UBA colaborar com os poderes públicos, como órgão especializado e técnico-consultivo, no estudo, equacionando as soluções dos problemas que se relacionam com a avicultura, visando ao seu aperfeiçoamento e ao de todos os seus setores (UBA, s/d). Além da gestação permanente junto aos órgãos oficiais, uma outra forma de "colaboração com os poderes públicos" são os "grupos de trabalho", compostos por representantes da associação e dos órgãos oficiais.

Por exemplo, as prioridades no plano de trabalho da diretoria de 1981 foram montadas para serem desenvolvidas

(...) numa ação conjunta com as entidades especializadas em setores específicos de representação, como a Apinco, a Abef, a Anfar, o Sindirações, o Sidan, além dos órgãos oficiais de pesquisa e os vinculados à política de crédito, fiscalização, fazenda e previdência social. Entre estas prioridades, segundo a diretoria, constavam alterações da incidência do ICM no comércio interestadual de matéria-prima, compulsoriedade no recolhimento do Proagro, definição da inspeção e fiscalização sanitárias, a questão do Funrural que não atrai mão-de-obra, incentivos às exportações, campanhas de aumento do consumo interno, elaboração de estatísticas etc. Neste mesmo ano, uma das prioridades era também a implantação de uma unidade de apoio em Brasília, contratando um executivo, a fim de manter um suporte político nas principais esferas de Governo(Realidade $\operatorname{Agroav}($ cola, maio de 1981, p. 5).

Em 1980, "por solicitação do Governo", foi criado um grupo de trabalho do qual a UBA fez parte para, com reuniões mensais, "acompanhar de perto o desenvolvimento do setor". Nesse mesmo ano, levantamentos sanitários da avicultura realizados pela UBA e apresentados à Secretaria de Defesa Animal do Ministério da Agricultura resultaram na formação de um "grupo de trabalho" composto por representantes do Ministério da Agricultura, Embrapa, UBA, Sidam (Sindicato da Indústria de Defensivos Agrícolas) e Instituto Biológico de São Paulo (Realidade Agropecuária, novembro de 1980, p. 14). Em sua atuação de caráter mais técnico-informativo, a UBA promove anualmente o Congresso Brasileiro da Avicultura, com participação das Organizações filiadas, órgãos oficiais, empresas e técnicos da avicultura. Além disso, a exemplo de outras associações, como a Apinco, realiza levantamentos estatísticos periódicos para previsão e controle de mercado.

Para se ter uma idéia da influência de organizações dessa ordem na formação de políticas, pode-se tomar como exemplo a atuação da UBA junto ao Governo, na regulamentação das normas higiênico-sanitárias, em 1980. Segundo seu presidente, 
quanto à complementação da famosa portaria 974, praticamente $99 \%$ das indicações que fizemos por intermédio da UBA ou do grupo de trabalho do Congresso de Belo Horizonte foram aceitas pelo Governo. Nós estamos agora enviando todos os elementos do departamento técnico da UBA para que a portaria seja relida. Queremos saber se o $1 \%$ modificado pelo Governo não é do interesse da avicultura. Neste caso, voltaremos a trabalhar para que seja modificado o projeto do Governo. (A Granja, janeiro de 1980, p. $63)$.

Cabe destacar que numa situação de estreita vinculação com os aparelhos estatais e ramificações interassociações, os efeitos da atuação de uma organização como a UBA e outras associações empresariais não resultam estritamente de pressões abertas e tomadas de posições explícitas. A própria presença integrada e constante permite o diagnóstico conjunto entre órgãos oficiais e organizações classistas, para a tomada antecipada de posições e a articulação de mecanismos e rearranjos que permitam o cálculo antecipado das condições de reprodução do capital, sua lucratividade, bem como os possíveis conflitos intersetoriais na apropriação dos excedentes. ${ }^{37}$ Mais adiante mostramos a diferença, em relação a esse aspecto, com as "associações de trabalhadores", sindicatos rurais etc.

Outra característica desse tipo de associativismo é a pressão no sentido de o Estado garantir condições de lucratividade, através da intervenção por meio de uma série de mecanismos, como administração de preços, subsídios etc. Quando essa lucratividade está ameaçada ou diminui por uma série de razões, entre elas a intervenção do Estado através do tabelamento, a bandeira de luta dessas associações passa a ser a defesa da "lei de oferta e procura". Implícita a esse comportamento está a estratégia de atuar no sentido de que o Estado crie as condições de lucratividade através da criação das condições de produção e só interfira no preço final em casos excepcionais. ${ }^{38}$

\footnotetext{
${ }^{37}$ Conforme seu presidente, a "UBA se propõe portanto a tentar se organizar antes que surjam os problemas. (...) Já estamos detectando as coisas antes que surjam, e com unia atuação na maioria das vezes discreta - principalmente junto à área governamental - estancos conseguindo a solução da maioria dos problemas" (A Granja, janeiro de 1980, p. 64). Conforme O'Donnell, as "limitações de atenção e de processamento da informação determinam que, para que as instituições do Estado dêem conta de um problema, alguém deve colocá-lo 'de fora' ou que de 'dentro', (...) alguém o defina como tal. Está muito distante das consciências dos sujeitos sociais e, mais ainda, da agenda de problemas das instituições estatais, abranger 'tudo o que interessa'. A capacidade de colocar um problema ou de definir uma situação como crise significa poder. Mais precisamente, supõe contar com recursos consideráveis de dominação" (O'Donnell, 1981, pp. 88-89). Os "períodos de escassa atividade em que essas associações não são muito mais que unia fachada podem ser não tanto lapsos, nos quais o Estado se impõe sobre a burguesia, mas aqueles cm que o excelente acesso de que goza a níveis menos agregados e seu acordo com as diretrizes gerais da política vigente tornam desnecessário outro papel para estas associações" (id., 1976, p. 52).

${ }^{38}$ Em seu relatório de 1979, por exemplo, sobre a questão da exportação de farelo de soja e seu tabelamento pelo Governo, consta que a "este respeito a UBA dirigiu-se ao Ministério da Agricultura, defendendo a liberdade de mercado para garantir o abastecimento de farelo de soja para a avicultura. Continuou nossa entidade a bater-se por mercados livres, não só dos produtos avícolas, mas também dos insumos necessários para produzi-los". Por outro lado, graças à "atuação da União Brasileira de Avicultura foi possível no ano passado à avicultura contar com o milho necessário para o seu abastecimento, e por preços inferiores aos vigentes no mercado. Desejamos deixar aqui consignada a valiosa cooperação do Ministério da Agricultura através da Comissão de Financiamento de Produção". Além disso, nesse mesmo ano foi firmado um convênio, através da UBA, entre o Ministério da Fazenda e as Secretarias da Fazenda dos
} 
No tocante a definição das políticas de exportação de produtos avícolas, a principal organização é a Associação Brasileira de Exportadores de Frangos - Abef, que passou a ter uma atuação destacada, inclusive, porque o desequilíbrio crescente do balanço de pagamentos se constitui num dos elementos básicos da crise do padrão de acumulação. Essa situação contribui para uma vinculação mais estreita entre a Abef e os órgãos oficiais, visto que a política de exportação faz parte das prioridades governamentais.

A formação da Abef se deu com o início das exportações brasileiras de frangos e, já então, estreitamente vinculada com as políticas de exportação.

No ano de 1973, uma reunião entre o Exmo. Sr. Ministro da Fazenda e líderes do setor avícola resultou na recomendação para que fossem iniciados os estudos que permitissem viabilizar a exportação de parte da produção nacional de carne de frangos. Posteriormente, no início de 1975, os abatedouros de frangos foram novamente convocados pelo Governo Federal desta vez através do Ministério da Agricultura, e lhes foi sugerido o imediato início das exportações, para que não se aviltassem os preços do produto no mercado interno. Com o apoio governamental, as exportações tiveram seu início em agosto de 1975. A ABEF foi fundada em 5 de novembro de 1976, para congregar esforços, no sentido de desenvolver e dinamizar as exportações brasileiras de frangos (ABEF, 1979).

$\mathrm{Na}$ época de sua formação, os países europeus e os Estados Unidos controlavam 94\% das exportações mundiais de carne de aves. Em 1979 o Brasil já despontava como um dos principais exportadores. A ABEF, neste ano, era responsável por cerca de 98,5\% das exportações brasileiras. Sua diretoria, em 1980, tinha como presidente o diretor do Grupo Perdigão, e como vice-presidente um diretor do Grupo Sadia, um da Rio Branco, um da Granja Betinha e um diretor da Coopave. Em 1979 a Associação era constituída por 17 sócios, representando especialmente empresas vinculadas a abatedouros, formadas por capitais privados nacionais e/ou externos, de cooperativas e públicos (Interbrás), inclusive uma antiga associação de exportações de frangos. ${ }^{39}$

Em 1981, a ABEF promoveu a Reunião Mundial dos Exportadores de Frangos, com o objetivo de formar uma associação internacional - a "Opep do Frango". Essa associação, a IPEA International Poultry Export Association -, foi formada basicamente pelo Brasil, EUA, França e Uruguai (70\% das exportações mundiais) e mais 21 países. Seu primeiro presidente é o mesmo da ABEF, UNEF e do Grupo Perdigão (Avicultura Industrial, fevereiro de 1981, pp. 16-17). A

Estados, isentando do ICM as exportações de reprodutores; gestionou-se para que o Ministério da Agricultura e o de Relações Exteriores resolvam os problemas de exportações de produtos avícolas para a América Latina (UBA, 1979).

${ }^{39}$ Em 1979 os associados da ABEF eram: Abatedouro Pif-Paf; Abatedouro Rio Branco; Chapecó Avícola; Com. e Ind. Saulle Pagnocelli; Companhia Avícola Minuano; Cooperativa Agrícola de Cotia; Cooperativa Agrícola Vale do Rio Taquari (Coopave); Frangosul S.A. Agro-Avícola Industrial; Frigorífico PortoAlegrense; Frigorífico Seara; Granja Betinha; Perdigão S.A. Comércio e Indústria; Petrobrás Comércio Internacional S.A. Interbrás; Sadia Concórdia S.A. Ind. e Comércio; Sociedade Avícola Louveira e UNEF - União Nacional dos Exportadores de Frangos. 
elaboração, os estatutos e a organização formal da associação ficou a cargo de uma comissão formada por três empresários franceses, três norte-americanos e três representantes do Brasil (o Diretor do Grupo Perdigão, UNEF e ABEF; o diretor executivo da UNEF e um diretor da Granja Betinha). A IPEA, a exemplo da UNEF e da ABEF, desenvolve também campanhas publicitárias a nível internacional no sentido de aumentar o consumo de carnes de aves (Avicultura Industrial, fevereiro de 1981, p. 16).

Além da ABEF, a Associação de Abatedouros Avícolas de São Paulo - Avesp, criou um pool de exportadores de frangos. Sua atuação maior tem sido no sentido da regulamentação higiênico-sanitária. A Avesp possui certas divergências em relação à ABEF, e a "condição básica para ser associado da Avesp, e também para que tenha a intenção de comercializar em todo território nacional, é que seu frigorífico ou abatedouro seja federalizado (SIF). Além dessa condição, que é necessária para exportação, o produtor precisa ter a produção própria daquilo que pretende exportar"(ibid.).

Os ramos industriais de produtores de rações e conexos têm no Sindirações - Sindicato Nacional de Indústria de Rações Balanceadas, na Anfar - Associação Nacional dos Fabricantes de Rações e no Sidan - Sindicato Nacional das Indústrias de Defensivos Animais, suas "corporaçõeslobby" principais. Visto que os produtos desses ramos industriais possuem um peso relativamente elevado - cerca de 70-80\% dos custos de produção - sua atuação no complexo avícola industrial, resguardando-se os interesses específicos, é extremamente entrelaçada e conjunta com outras associações do gênero, como, por exemplo, a UBA. Acresce ainda que, em decorrência do processo de integração e do grau de oligopolização, a maior parte das empresas que atuam na integração avícola, tanto horizontal quanto vertical, são produtores de ração de algum grau. Portanto, mesmo ao nível de organização da produção, as empresas vinculadas ao complexo avícola industrial participam de diversos ramos e setores produtivos, o que aumenta o entrelaçamento da atuação corporativa. Esse aspecto é reforçado com a tendência à aglomeração, processo que na avicultura industrial tem tido um ritmo acelerado. Uma mesma empresa tende a abarcar os mais diversos setores produtivos, com exceção, em geral, da produção estritamente agropecuária.

Fundado há 25 anos, o Sindirações possuía em 1980302 empresas filiadas. Criado inicialmente para ser o sindicato das indústrias de rações de São Paulo,

Desde 1967 o Sindicato levantou uma bandeira nacional para atender os interesses do setor econômico ligado diretamente à Reforma Tributária implantada naquele ano. Desde aquela data assumiu a coordenação de todo o País das ações que resultaram no (sic) Ato complementar n. 4 do Executivo Federal, que isentou as rações concentradas e suplementos do pagamento do ICM. Os problemas relativos ao abastecimento interno de matérias-primas básicas, tais como farelo de soja e milho, exigiram do Sindicato também uma ação nacional, quando assumiu perante o Governo a coordenação e distribuição em 
todo o Território Nacional desses produtos. A participação do setor junto à Cacex, ao Conselho de Política Aduaneira, ao Conselho Interministerial de Preços, ao Difisa, junto ao Ministério da Agricultura, à Comissão de Financiamento da Produção, nos seminários e congressos de ordem nacional e internacional, exigiu uma representatividade de ordem participativa em todo o país" (...) (Realidade Agroavícola, janeiro de 1979, p. 3). Em 1979 o Sindirações passou a ter, oficialmente, caráter nacional.

Segundo seu presidente em 1980,

Em cada Estado existe unia delegacia, sediada na capital, cujas atividades são coordenadas por um empresário local no setor que tem a representatividade da classe. Uma das primeiras vitórias do Sindicato, depois que Salvador Firace assumiu a Presidência, em 1968, foi a isenção do ICM também para aves, ovos e pintos de um dia. A ração já era isenta e Salvador Firace não achava justa essa discriminação. Depois de ter participado de oito reuniões com secretários da Fazenda, conseguiu seu objetivo em 1969 e, no final de 1970, toda matéria-prima para produções de rações ficou isenta em todo o território Nacional. (...) Hoje, a produção de carne de frango, que era de 150 mil toneladas/ano atingiu 1 milhão de toneladas, a produção de ovos subiu de pouco mais de 200 milhões para quase 800 milhões de dúzias e o número de indústrias de rações passou de 19, no início da década de 1970, para 302. (...) Outro trabalho de importância, realizado pelo Sindicato, foram 11 convênios, firmados num período de dez anos, com as universidades rurais do Norte, Nordeste e Sul para utilização de produtos regionais, até então inaproveitáveis. (...) Foi também sob a atual gestão que o Sindicato conseguiu motivar o apoio dos Governos estaduais e federal, possibilitando o crescimento da avicultura em todas as regiões. Um fato importante, na opinião de Salvador Firace, é que a avicultura passou a se constituir, principalmente, num fator social além de econômico, resolvendo problemas de abastecimento e promovendo a fixação do homem à terra. (...) $\mathrm{O}$ apoio governamental veio também no setor de financiamento (Avicultura Industrial, março de 1981, pp. 7-8). (Grifo nosso).

Para se ter uma noção do intercruzamento do sindicato a nível de diretorias na mediação de interesses, convém mencionar os seguintes elementos. Seu presidente em 1980, por exemplo, era também presidente da Bolsa de Cereais de São Paulo desde 1976, diretor da Fiesp, da Associação Comercial de São Paulo, membro do Conselho Estadual de Nutrição, membro do Conselho Agrícola de São Paulo, presidente do Grupo de Assessoria e Participação e da Ceagesp. Já seu secretário-geral era também conselheiro da Associação Comercial de São Paulo e da UBA, diretor da APA - Associação Paulista de Avicultura e do Sindicato da Indústria do Milho e da Soja no Estado de São Paulo. Além de diretor-tesoureiro era também tesoureiro da Bolsa de Cereais de São Paulo (ibid.).

Em 1980 o Sindirações assinou um convênio com a FEFAC - Federação Européia dos Fabricantes de Alimentos Compostos para Animais, com sede em Bruxelas, que congrega cerca de $72 \%$ da fabricação européia de rações balanceadas, equivalendo a cerca de 75 milhões de toneladas anuais ou a cerca de 27 bilhões de dólares. Como os países membros importam cerca de 6 milhões de toneladas de farelo de soja, em sua maior parte dos EUA, um dos principais interesses da FEFAC no Brasil, segundo seu presidente, é o farelo de soja. 
Ao visitar o Brasil em 1980, com o patrocínio do Sindirações, a FEFAC, além do objetivo de examinar a qualidade da produção brasileira de matéria-prima, visava à discussão das condições de exportação com o Governo brasileiro. Segundo o presidente da FEFAC, "o sistema de licenças dificulta a exportação de farelo de soja brasileiro, porque as indústrias de rações européias devem dar aos clientes, por todo o tempo, um preço estável. (...) Gostaríamos ainda de ter garantias de que o Brasil não fará um embargo, como o realizado pelos EUA." 40

Outra atividade desenvolvida pelo Sindirações e organizações congêneres como a Anfar é a difusão do neo-malthusianismo e suposta necessidade de incrementar a modernização da produção agropecuária, como única alternativa para se "chegar à paz", ideologia essa elaborada ou formada nos centros internacionais de pesquisa sustentados pelo grande capital internacional (Realidade Agroavícola, dezembro de 1978, pp. 7-8).. Isso é complementado com propostas de subsídios oficiais à alimentação, maior distribuição pela Cobal, benefícios à exportação, aumento do crédito rural, em síntese, que diminua o subconsumo alimentar e aumente o mercado (id., julho de 1981, p. 12).

Apesar de a Anfar atuar em conjunto com o Sindirações e apesar das freqüentes declarações de sua diretoria no sentido de ter sido formada para uma atuação conjunta, essa organização caracteriza-se por congregar grandes produtores envolvidos mais especificamente com a produção de rações. Sua fundação deu-se em 1980 e os membros da primeira diretoria eram representantes da Duratex, Purina, Rações Dutra, Anderson Clayton, Cargill e Fri-Ribe. Como se vê, sua diretoria (cujo diretor é presidente também da Sociedade Paulista de Medicina Veterinária) era formada quase que exclusivamente pelo grande capital preponderantemente externo e envolvido fundamentalmente com a produção das matérias-primas de ração (cereais e aditivos químicos), o que a diferencia do Sindirações e leva a supor que os interesses sejam bastante marcantes. Quanto às suas vinculações com os órgãos oficiais, o processo é semelhante. ${ }^{41}$ Já em 1981, encabeçava a diretoria da Anfar o vice-presidente da Duratex - Rações Anhanguera, que se recomendava "(...) por sua

\footnotetext{
${ }^{40} \mathrm{O}$ representante do Ministério da Agricultura foi pouco redutível no tocante às cotas de exportação. Para ele o sistema de cotas "é preciso, nesse momento, para controlar problemas de abastecimento interno. Mas, com o tempo, aperfeiçoamentos serão introduzidos no processo para permitir que se faça uma programação com matérias-primas brasileiras." Sugeriu à Fefac que adquirisse também outras matérias-primas brasileiras, com núcleo protéico, com base em reivindicações do Sindirações e empresas do setor. "As idéias do representante do MA (Ministério da Agricultura) justificam-se. A busca de mercados externos é urna das perspectivas para as indústrias nacionais de rações que produziram 12.400.000t em 1979 e, cuja produção estimada para esse ano (1980) é de 14.500.000t" (Avicultura Industrial, março de 1980, pp. 12-20).

${ }^{41}$ Conforme a "Carta de Princípios" da Anfar, a "preservação do sistema econômico nacional é responsabilidade da classe empresarial. A identificação deste principio implica na aceitação de obrigações consentâneas com este objetivo básico. (...) Nenhuma empresa, de qualquer porte ou atividade, pode progredir se não encontrar condições econômicas e políticas propícias". Uni de seus objetivos básicos é "(... ) o seu papel de vigilância em relação aos atos governamentais (...) a mensuração dos efeitos inflacionários e outras consequiências econômicas causadas pelos regulamentos governamentais, gastos, taxações" (...) (Avicultura Industrial, setembro de 1980, pp. 14-15). (Grifo nosso).
} 
vivência política como presidente da Associação Brasileira dos Exportadores."

A ação da Anfar desenvolveu-se especialmente no sentido de planejamento da produção, análise do desempenho do mercado de matérias-primas, estratégias de comercialização, promoção de consumo, avalização e acompanhamentos de safras agrícolas, garantias pelo Governo de abastecimento interno de matérias-primas, financiamentos e formação de estoques reguladores. Para a execução dessas atividades a Anfar forma "Comissões de Trabalho". Em 1981, por exemplo, existiam a Comissão de Tecnologia, a Comissão de Abastecimento e a Comissão de Mercado, assessoradas por uma Comissão Fiscal. Essas comissões eram compostas quase exclusivamente por representantes da Purina, Anderson Clayton, Cargill, Rações Dutra, Fri-Ribe, Duratex, Socil e Central Soya. Outra iniciativa da Anfar "(...) prende-se à promoção de palestras a cargo de especialistas na área econômica, através das quais se tem procurado aumentar o convívio do setor com as nuanças da política, tanto quanto possível aproximando Governo e Empresa" (Realidade Agroavícola, abril de 1981, p. 14).

O Sidan - Sindicato Nacional da Indústria de Defensivos Animais reúne 77 das cerca de 80 empresas do parque industrial brasileiro de veterinária. A avicultura representa cerca de $40 \%$ do mercado da indústria veterinária. Essa organização começou a atuar em 1966 e passou à condição de entidade de âmbito nacional em 1972 (Realidade Agroavícola, maio de 1980, p. 20). Suas atuações têm-se concentrado nos problemas causados ao setor pela política de restrições às importações; e na política de controle higiênico-sanitário. Como boa parte da matéria-prima para determinados insumos sofisticados e mesmo produtos acabados são importados, a política de restrições às importações tem como um dos objetivos o aumento da produção interna. $\mathrm{O}$ principal argumento utilizado pelo Sidan é o caráter de exportação da avicultura brasileira, sendo, portanto, geradora de divisas, compensando assim as importações. Nesse sentido essa organização é reforçada pelo Sindag - Sindicato de Indústria de Defensivos Agrícolas ${ }^{42}$. Além disso, segundo um de seus dirigentes, "há que se destacar, no trabalho do Sidan, a harmonização do setor, já que as chamadas multinacionais oferecem sua colaboração tecnológica no mercado internacional, e a indústria veterinária brasileira fornece a recíproca com importantes conquistas em âmbito políticoeconômico" (ibid.).

Essas organizações de cunho mais geral e nacional complementam-se com outras de características locais ou de ramos de produção. As de cunho local são principalmente as associações

\footnotetext{
${ }^{42}$ Conforme declarações do gerente de operações da Du Pont do Brasil para o Cone Sul em relação à "crise" do setor: "As empresas de pesticidas já estavam operando com lucros reduzidos, devido aos altos custos do petróleo, das matérias-primas e ao acordo entre o Sindicato de Indústria de Defensivos Agrícolas (Sindag) e o Afinistério da Agricultura, que determinou a margem de lucro das empresas. Nós entendemos as dificuldades do Governo em suas tentativas de reduzir a inflação e evitar a importação de produtos. Mas a indústria de defensivos agrícolas precisa importar matériasprimas (...)" (Avicultura Industrial, dezembro de 1980, p. 10). (Grifo nosso).
} 
estaduais e mesmo municipais ou microrregionais, naquelas regiões onde a avicultura é relativamente forte. Como exemplos das organizações voltadas especificamente para um ramo de atividades, e que interagem com as organizações mais gerais, podem ser tomadas a Apinco Associação dos Produtores de Pintos de Corte, a Unac - União dos Avicultores de Corte etc. Por suas próprias características, esse tipo de associação tem uma atuação mais voltada para problemas de preços (de insumos e produtos finais) e de mercado que, por exemplo, às políticas de exportação e abastecimento.

Um tipo de questão que tem envolvido associações como a Unac e a Apinco é o processo de integração sob o qual a avicultura tem avançado na última década. A intensidade com que essas organizações se têm envolvido na questão da integração é possivelmente decorrência do fato de terem sido formadas com base em São Paulo, onde a antiga avicultura comercial era relativamente forte. A readaptação que a avicultura industrial estaria a exigir desses setores ou, segundo essas organizações, a "crise" que a antiga avicultura atravessa, provoca atuação mais intensa. ${ }^{43}$ Em certas regiões de Minas Gerais, como o Sul, acontece coisa semelhante, ao contrário dos Estados sulinos, onde não preexistia uma avicultura comercial, pelo menos com força suficiente para criar resistências.

A relevância maior das associações a nível regional ou local é que se constituem fundamentalmente em "associações de criadores". Portanto, nas regiões onde a expansão da avicultura não se dá pela integração vertical, essas organizações fazem a vinculação entre os criadores, integrados ou "autônomos", empresariais ou camponeses, com as organizações empresariais de maior abrangência. É importante atentar para o caráter interclassista dessas organizações, quando se trata da integração horizontal e, portanto, com subordinação do campesinato selecionado para fazer parte da integração ou de produção camponesa "autônoma". Praticamente não existe nenhuma região ou Estado em que a produção avícola seja exclusivamente integrada

\footnotetext{
${ }^{43}$ Segundo o presidente da Apinco, "estaríamos numa outra fase da avicultura irreversível, creio eu, em que, nos moldes de outros ramos produtivos, somente os empresários melhor organizados sobreviverão". Para os demais existiriam duas opções: sumirem do mercado ou se integrarem (Avicultura Industrial, dezembro de 1980, p. 10). Em São Paulo existia unia avicultura relativamente forte, baseada na organização empresarial no tocante ao processo de trabalho de criação. Com o surgimento da integração horizontal como unia nova modalidade de organização de boa parte da avicultura brasileira e a formação de novas frentes de expansão altamente subsidiadas e com boas condições de lucratividade, como no Centro-Oeste etc., essas antigas empresas são forçadas a se readaptar e a defender o lucro médio. Acontece que, na integração horizontal, o produtor não conta com o lucro médio, ao contrário da avicultura organizada em empresas de criação de aves em bases capitalistas. Conforme declaração de dirigente da Unac: "Através da Unac, acho que podemos conseguir maior conscientização dos criadores associados à entidade. Creio que assim teremos uma melhor divisão de rentabilidade de cada um. E justo que o criador tenha sua fatia de lucro que hoje está sendo marginalizada." E em outra ocasião: "Ou nos estruturamos para termos lucros médios, ou não dá mais. (...) É preciso que as integrações se conscientizem de que não se podem aproveitar deste momento de desespero para abusar do avicultor integrado aviltando o seu ganho, transformando-o num sujeito espoliado, num colono mal remunerado." É significativo que a linha de atuação da APA - Associação Paulista de Avicultura - também seja nessa direção (Avicultura Industrial, abril de 1981, pp. 20-22 e abril de 1980, pp. 39-42).
} 
horizontalmente ou através de integração vertical, ou mesmo de produção camponesa "autônoma". Em geral, onde a avicultura é relativamente desenvolvida, o que existe é a predominância de uma dessas formas, coexistindo com outras. Inclusive nas regiões onde predomina a integração horizontal, como no Sul, por estratégia das próprias empresas integradoras, ao mesmo tempo em que estas produzem uma parte da matéria-prima, sendo, portanto, criadores, nem todos os produtores são integrados contratualmente, sendo boa parte relativamente "autônoma". Acontece que praticamente todas as "associações de criadores" são constituídas por todos os criadores de aves, seja em bases familiares ou em grandes empresas, integrado ou integrador.

Existem associações locais em praticamente todos os Estados onde a avicultura é relativamente desenvolvida. Assim, em Santa Catarina, além da Acrave existe a Acav - Associação Catarinense de Avicultura. No Rio Grande do Sul, a Associação Gaúcha de Avicultura - Asgav congrega tanto produtores como abatedouros e fabricantes de rações. No Paraná a Apavi Associação Paranaense de Avicultura, juntamente com organizações congêneres, vem tendo uma forte atuação em relação aos órgãos governamentais, tendo em vista em especial a regulamentação higiénico-sanitária e problemas de mercado e preços (Realidade Agroavícola, dezembro de 1980, p. 62). Em São Paulo e outros Estados existem, entre outras, a APA - Associação Paulista de Avicultura; AAD - Associação dos Avicultores de Descalvado; ANA - Associação Nordestina de Avicultura; AFA Associação Fluminense de Avicultores; Avpe - Associação Avícola de Pernambuco; Aamavi - Associação Amazonense de Avicultura; AGA - Associação Goiana de Avicultura; AAMG - Associação dos Avicultores de Minas Gerais; ABS - Associação Brasileira de Sexadores de Aves de um Dia e muitas outras.

O que a Acrave, fundada em 1979 em Santa Catarina, tem de específico e relevante para um exame das associações é o fato de ter surgido explicitamente como uma organização que somente admite como associados os produtores de aves. Acontece que em Santa Catarina, a exemplo dos demais Estados do Sul, a produção de aves está a cargo quase que exclusivamente de produtores integrados horizontalmente e em boa medida, por contratos. Portanto, nas atividades de criação nesses Estados existem poucas empresas envolvidas diretamente na produção, que está a cargo do campesinato. Trata-se, é claro, de um campesinato com situação socioeconômica acima da média. Para se conseguir acesso à integração, o candidato passa por uma rigorosa seleção, visto que as empresas integradoras têm condições de escolha, pelo excesso de pretendentes. Esses elementos e o fato de a avicultura de Santa Catarina ser um setor dos mais desenvolvidos fundamentam a formação da Acrave.

Um dos objetivos da Acrave, além da busca de desenvolvimento tecnológico e informativo da avicultura, é congregar "criadores, pessoas físicas e jurídicas que, por suas atividades, estejam 
ligados diretamente à criação de aves, vedada a participação dos que industrializam o produto". Apesar de ser uma associação essencialmente dos produtores de aves integrados, o sentido de sua ação não foge do corporativismo, na medida em que é formada de agentes sociais de uma determinada atividade do ciclo produtivo do complexo avícola industrial. A posição desses agentes frente ao capital e ao trabalho não vem ao caso, podendo ser inclusive pessoas jurídicas, ou seja, empresas. O mesmo acontece com os demais objetivos da associação, todos eles voltados para uma melhor divisão dos excedentes, mas ao mesmo tempo dentro da "racional idade" proposta pela dinâmica da acumulação do capital e pela atuação do Estado. ${ }^{44}$ Evidentemente, por se tratar de uma associação fundamentalmente de avicultores e, por isso, de produtores camponeses, o que está em questão não é a obtenção do lucro médio, a exemplo da Unac etc., mas uma melhor participação nos excedentes, e portanto, uma maior remuneração do trabalho familiar, dentro da racionalidade do capital. Acontece que os integrados são produtores que, embora não atuem em busca de taxa média de lucro e, inclusive, na maior parte dos casos, com uma baixíssima remuneração de trabalho, são produtores altamente selecionados. Desse modo, em relação aos demais produtores, se não contam com uma boa remuneração de trabalho, contam com certa segurança e garantia, real ou imaginária, o que não é caso dos excluídos da integração. Em outras palavras, são produtores que foram "filtrados" sócio-economicamente e continuam sendo "filtrados" politicamente. Nesse sentido, a Acrave realiza aquilo que os sindicatos não têm condições de realizar.

Apesar dos limites bastante restritos da proposta de organização da Acrave e seu direcionamento no sentido de não pôr em questão o processo de acumulação, mas simplesmente buscar distribuição mais equânime dos excedentes, sua criação não impediu uma violenta reação das demais organizações, nem o apoio do sindicalismo e de setores da Igreja. Segundo seu presidente, o que a Acrave procura é "defender um mercado livre para o frango", porque "(...) os preços regidos pela lei da oferta e da procura só virão beneficiar o criador de aves". Isso se tornaria difícil sem uma organização própria "(...) porque a Associação Catarinense de Avicultura atua a nível de empresários, sendo que a nossa está voltada aos interesses dos criadores de aves" (A Granja, abril de 1980, p. 7). Se, de um lado, a associação foi apoiada em sua criação pelos sindicatos de trabalhadores rurais, cooperativas, igrejas etc., de outro, a reação das demais associações, em especial a Acav representando os interesses das empresas integradoras, abrangeu

\footnotetext{
${ }^{44}$ Entre outros objetivos estatutários da Acrave figuram: "Defender os interesses e direitos da classe. (...) Colaborar com os Poderes Públicos, como órgão especializado e técnico consultivo, no estudo de solução de questões que se relacionam com a avicultura, visando o aperfeiçoamento, o desenvolvimento e a propaganda da avicultura em geral. (...) Aperfeiçoar e desenvolver a avicultura mediante a criação de um aviário experimental (...) através de acordos e convênios com entidades oficiais e particulares, nacionais e estrangeiras." E, por fim, a "associação agirá como órgão de colaboração com os poderes públicos e demais associações no sentido de solidariedade social e de subordinação dos interesses econômicos ao interesse nacional" (Acrave, 1979).
} 
desde processos judiciários até a cooptação dos avicultores para os jogar contra a Acrave. Mais tarde, passou-se à tentativa de cooptação da Acrave para uma fusão com a Acav, "para promover a união das associações". ${ }^{45}$

Em termos empresariais, há ainda outras formas de organização ou mediação de interesses, menos formais. Entre estas, no complexo avícola, destacam-se os "Clubes do Galo" e a participação de diretores de empresas em cargos públicos do Legislativo e do Executivo. O "Clube do Galo" é um tipo de organização que reúne os empresários vinculados de alguma forma ao complexo avícola, cuja finalidade é formalmente recreativa, existindo em todos os Estados em que a avicultura é significativa. Suas reuniões são mensais, sempre em rodízio, sendo um empresário o responsável e patrocinador. Nessas festas ocorrem palestras, exibições de filmes etc. Esses clubes reúnem os empresários mais diversos vinculados ao setor e o patrocinador é, via de regra, um grande fornecedor de insumos, indústria de transformação, ou mesmo, agente financeiro público ou privado ou ainda uma associação de criadores de aves, cooperativa etc. ${ }^{46}$

\subsubsection{ASSOCIATIVISMO DO TRABALHO}

A discussão anterior das principais organizações dedicadas à representação e mediação política de interesse de complexo avícola adquire maior relevância na medida em que a elas contrapomos organizações de outra natureza, vinculadas ao mesmo setor. Ou seja, às associações representantes de interesses empresariais devem ser contrapostas aquelas associações de cunho

\footnotetext{
${ }^{45}$ Segundo o Presidente da Acrave, na "verdade, a Acav não defende os interesses dos avicultores (...) defende os interesses dos frigoríficos e das fábricas de rações. Por isso, não divulgam a existência da Acav para conseguir mais associados entre os avicultores. Todos os grandes já são sócios. Daí eles alegarem que não poderiam existir duas associações.

${ }^{46}$ Por exemplo, a programação do "Clube do Galo" de Santa Catarina para o primeiro semestre de 1981 estava a cargo das seguintes empresas: mês de abril, com a Anderson Clayton, em Curitiba; em maio, com a Storck, em São Paulo; junho, Cobb do Brasil; julho, BRDE -- Banco Regional de Desenvolvimento do Extremo Sul (oficial), em Florianópolis. Na programação do "Clube do Galo Gaúcho" para 1981, constam os seguintes patrocinadores: Casp, Pfizer, Coopavc (Cooperativa de Aves do Alto Taquaril, Soei), Frangos Chezini, Cargill, Corpave, Frinal e Asgav. Para se ter uma idéia da vinculação dos "Clubes do Galo" com as associações pode-se tomar como exemplo a eleição da nova diretoria da Acav em 1980. "Em reunião ordinária para aprovação das contas da gestão Arlindo Paludo, presidente da Acav -Associação Catarinense de Avicultura, e eleição da nova diretoria que regerá os destinos da entidade, foi eleita, por aclainação, a chapa encabeçada por Afonso Back, após o almoço do Galo Catarinense" (Avicultura Industrial, maio de 1980, p. 33).

Sobre a vinculação direta entre diretores de empresas e cargos públicos no complexo avícola, os melhores exemplos talvez sejam representados pelo Grupo Perdigão e pelo Grupo Sadia. O Grupo Sadia, através de diretores seus, já ocupou duas vezes a Secretaria da Agricultura de Santa Catarina, além do cargo de vicegovernador, também por duas vezes consecutivas. Além disso, seu fundador, um dos principais diretores acionistas, foi senador pelo PDS e deputado federal pela Arena. Já o Grupo Perdigão ocupou por duas vezes consecutivas a Secretaria da Fazenda do mesmo Estado (Negócios em Exame, 2 de julho de 1980, p. 27). Já o vice-presidente da Granja Rezende que assumiu em 1980 fez parte da diretoria do Crédito Rural do Banco Central e foi presidente do Banco Nacional de Crédito Cooperativo nos Governos Geisel e Figueiredo (Avicultura Brasileira, março de 1980, p. 9).
} 
explicitamente mais classista e que, por sua natureza, não seriam necessariamente associações ou organizações de cunho empresarial e, portanto, não estariam em busca da "racionalidade" da acumulação, nem na defesa da distribuição intersetorial da mais-valia. Referimo-nos aos sindicatos de trabalhadores rurais e suas federações, às cooperativas agrícolas aos setores das igrejas etc. Por conseguinte, trata-se de associações que extrapolam o complexo avícola enquanto tal e se vinculam à questão geral do processo de diferenciação na agricultura brasileira, na qual a avicultura representa um dos casos típicos.

Contraditoriamente, essas associações e setores envolvidos com "trabalhadores rurais" em geral, ao mesmo tempo em que se contrapõem às associações empresariais, as complementam e prolongam. Uma das razões dessa "complementaridade" - se bem que contraditória - é o caráter heterogêneo do campesinato. Heterogeneidade que o próprio processo de "modernização" e integração da agropecuária reforça sem necessariamente aprofundar as relações de produção tipicamente capitalistas. A integração horizontal exemplifica isso, na medida em que o processo de integração e subordinação dos produtores agrícolas supõe uma rigorosa seleção. Desse modo, os produtores integrados são "filtrados" entre uma enorme massa de campesinato que, embora sócioeconomicamente não esteja necessariamente em condições muito abaixo dos integrados, contam com determinadas garantias (financiamento, mercado etc.) que os transformam num estrato especial de camponeses. Ao contrário da massa de camponeses excluídos do novo patamar técnicoprodutivo, esses produtores contam com altíssima produtividade física do trabalho. Se isso não significa necessariamente melhores condições materiais de vida, a sua integração ao nível produtivo supõe em princípio a integração também psico-ideológica, pelo menos numa primeira fase. ${ }^{47}$ Quando termina essa fase, a empresa integradora conta com a possibilidade de mudar o patamar técnico-produtivo, aumentando assim as exigências em capital e tecnologia, e de resselecionar os produtores integrados. É claro que esses aspectos sócio-econômicos por si sós não explicam o comportamento das "associações de trabalhadores rurais". Apenas dão suporte à "racionalidade" e à institucionalização proposta (ou imposta).

Quanto ao cooperativismo, não é difícil entender seu comportamento estritamente empresarial, visto que, no caso da avicultura industrial, trata-se de um setor altamente empresarial e também altamente seletivo no tocante ao quadro de associados. ${ }^{48}$ Praticamente não existem nem po-

\footnotetext{
${ }^{47}$ É significativo o fato de que todas as grandes empresas integradoras possuam meios de comunicação próprios, como rádios, jornais etc., além da assistência técnica, que evidentemente não se restringem à vinculação da tecnologia em si.

${ }^{48}$ Para se ter uma idéia da alta seletividade dos produtores rurais na avicultura industrial, mesmo quando se trata de unia cooperativa, pode-se tomar a Coopave, unia das principais do setor. "A área de ação da Coopave é composta de 56 municípios (Rio Grande do Sul e Rio de Janeiro) com 1.297 associados em dezembro de 1980. O faturamento, conforme relatório da Coopave, foi de 4.738.370.821,20 (em cruzeiros de 1980) com um resultado de CrS 289.711.865,79, sendo que $\mathrm{CrS}$ 141.945,86 foram integralizados em cotas partes: Reni Pedro Ely previa um
} 
deriam existir diferenças substanciais entre as cooperativas vinculadas à avicultura industrial e as empresas integradoras, pelo menos em relação à mediação de interesses, comportamentos próprios pelas contrapressões de segmentos de produtores.

A constituição e atuação de uma associação como a Acrave, referida anteriormente, para ficar no complexo avícola, é mais significativa do que pode parecer à primeira vista. Com o processo de implantação do Estado autoritário e as novas formas de exercício do poder, organizações como a Acrave - e de certa forma certos tipos de cooperativismo agrícola e mesmo alguns sindicatos rurais - passaram a representar interesses de determinados estratos camponeses. Isto é, daqueles que conseguem alcançar os novos patamares tecnoprodutivos, na medida em que atuam estritamente dentro dos moldes adotados. Ou seja, se de um lado tais organizações conseguem uma certa intensidade na realização de determinados interesses do moderno campesinato, de outro, sua atuação restringe-se necessariamente àquilo que se convencionou chamar de "lutas econômicas". Sua ação, por exemplo, dificilmente extrapola a luta por melhores preços, apoio governamental, criação de infra-estrutura de produção e comercialização etc. Esse tipo de ação tem como estratégia básica a utilização da produção como instrumento de luta, através, por exemplo, de boicotes à comercialização e da recusa em responder aos apelos e apoio governamental ao aumento da produção. Mais recentemente tende a se ampliar essa estratégia recorrendo-se às demonstrações de força, através de "passeatas", "acampamentos" etc. Outra característica básica é a mobilização "setorial", vinculada apenas a um problema bem definido e específico. 0 fato de esse tipo de participação política estar ligado principalmente à realização de interesses dos estratos modernos do campesinato e da burguesia rural não significa que não mobilizem também partes dos demais setores camponeses.

Além de esse tipo de lutas estar respaldado na "racionalidade" do Estado autoritário - o que, é lógico, não significa dizer que está a seu favor - e na heterogeneidade do próprio campesinato, o próprio controle administrativo-legal do sindicalismo rural dificulta o desdobramento das lutas para além das questões mais específicas e "econômico-administrativas". A legislação sindical rural pós1964 é tão interclassista quanto as associações acima referidas, apesar da diferença básica de que as associações empresariais são de caráter eminentemente civil e o controle sindical é de cunho corporativo estatal. Inclusive a mudança dessa legislação tem sido uma das principais lutas de boa

faturamento para 1981 de 12 milhões de cruzeiros. Dentro dos planos de expansão da cooperativa está em tudo a produção de álcool de mandioca e sua utilização na alimentação; plantio de 30 mil hectares de milho para as suas indústrias de ração; estímulo da produção de hortigranjeiros além da expansão para atender importadores" (Gazeta Mercantil, 24 de abril de 1981, p. 32). Nesse mesmo ano a cooperativa passou a ser importadora exclusiva da linhagem HR N para a América Latina. Para se ter uma idéia da seletividade, basta comparar os números de seu balanço com o reduzido número de associados, apesar de que a mesma tem como área de ação justamente as regiões com mais "minifúndios". 
parte do sindicalismo e suas federações.

Como se sabe, o enquadramento sindical passou a ser feito de acordo com o "módulo" do produtor rural, em substituição ao enquadramento conforme as relações de trabalho, previsto pela OIT - Organização Internacional do Trabalho. Desse modo, essa legislação - Decreto-lei ${ }^{\circ} 1.666$ ao mesmo tempo em que força os assalariados e trabalhadores rurais congêneres a pertencerem ao mesmo sindicato de parte do campesinato "autônomo" com base no trabalho familiar, força também boa parte do campesinato "autônomo" a se vincular aos sindicatos patronais, ainda que não tenha empregado algum. ${ }^{49}$

De qualquer maneira, a questão primeira tanto para o sindicalismo rural, nesse contexto, quanto para qualquer outro tipo de associativismo, é a exclusão de absolutamente qualquer canal político efetivo para a maior parte dos trabalhadores. Pior que o assistencialismo e a reduzida força que têm as "lutas econômicas" dos estratos camponeses integrados para garantir-lhes uma menor taxa de exploração de trabalho, é o que representa esse tipo de sindicalismo. Na medida em que foi implantada a "nova ordem" econômica e institucional, na qual não cabe questionamento institucional, a participação política foi reduzida a uma política estritamente econômico-administrativa, como se a sociedade fosse constituída exclusivamente por empresários. Ora, no caso da maior parte do campesinato, que constitui aquilo que pode ser designado por "antigo campesinato" ou "campesinato em degeneração", não se trata de uma questão econômico-administrativa, mas fundamentalmente de um problema político institucional. ${ }^{50}$ Para esses setores e esse tipo de questionamento não existe canal político efetivo, a não ser na medida em que se trata de "produtores" e por isso teria alguma coisa a ver com as "lutas econômicas". Em outras palavras, ao "afunilamento econômico" representado pela progressiva filtragem daqueles que farão parte dos novos patamares da produção, corresponde um "afunilamento político", na medida em que a participação e os canais políticos estão condicionados à forma e grau de participação na produção.

Para se apreender a estrutura e o funcionamento do atual sindicalismo rural, bem como a

\footnotetext{
${ }^{49}$ Mais tarde, através da Instrução 113, tentou-se considerar o filho de camponês "autônomo" maior de 18 anos como empregado da unidade produtiva para a qual trabalhava. Desse modo, quase todo o campesinato poderia ser enquadrado no sindicato patronal. Essa instrução foi abolida.

${ }^{50}$ Nesse sentido são significativas as novas formas de luta postas em prática por esse tipo de camponeses, em especial as relativas à questão da terra. As invasões de latifúndios por posseiros, que era uma das características da fronteira agrícola, passaram a ser uma tentativa de solução de problemas também de pequenos produtores nos Estados do Sul. Se de uri lado essas "invasões" estão vinculadas à crescente seletividade da fronteira agrícola, de outro, põem a nu a inexistência de qualquer canal político efetivo. Em geral, no Sul, esses camponeses invadem latifúndios sem cobertura formal de absolutamente nenhum tipo de associação ou instituição, ainda que, quando o fato está consumado, recebem "solidariedade" formal de determinados sindicatos e associações. Por outro lado, é significativo que as demais lutas das associações e sindicatos, aquelas "lutas econômicas", têm sempre como bandeira de fundo a "cobrança" da implantação do Estatudo do Trabalhador Rural, isto é, uma concessão institucional feita pelo Estado autoritário em sua formação e não posta em prática.
} 
forma de sua vinculação com questões como a exclusão e marginalização da maior parte do campesinato - processo no qual a avicultura é um caso típico - é necessário fazer referência às suas próprias origens. Nesse sentido, além do Estado autoritário, entram em pauta também outros tipos de organizações e formas de participação política, em especial setores da Igreja e os antigos movimentos de diversos matizes da época da derrocada do populismo.

Como se sabe, na formação do atual sindicalismo rural entrou em jogo uma série de movimentos sociais, entre os quais se destacam as Ligas Camponesas no Nordeste e os movimentos em favor da "reforma agrária" no Sul. Nessa região, os movimentos foram encabeçados especialmente pela Frente Agrária Gaúcha de setores da Igreja católica, em oposição ao suposto radicalismo das Ligas Camponesas. Esses setores da Igreja se respaldavam nas parcelas de camponeses médios com origens na imigração. Paralelamente a esses movimentos, já no final do período populista, surgiram movimentos constituídos por pequenos camponeses sem terra, nos quais recaiu a maior carga da repressão organizada, com o apoio dos setores "reformistas" da Igreja, daquele período. ${ }^{51}$

O que importa reter é que a formação e consolidação do atual sindicalismo rural estão condicionadas por essas forças sociais sob a égide do Estado autoritário e do redirecionamento da forma de exercício do poder pelas diversas classes sociais. É significativo, por outro lado, que é justamente com a consolidação do Estado autoritário que se efetiva a sindicalização rural em massa.

É desse contexto sócio-político de liquidação dos antigos movimentos sociais que resultou a formação do sindicalismo rural e a transformação das bases do exercício do poder. Isso deixa clara a estreita margem sobre a qual o sindicalismo se move. Para se ter uma noção da natureza proeminentemente "econômica" das lutas encaminhadas pelos sindicatos e federações de trabalhadores rurais e da distância que separa o poder de suas pressões daqueles das associações de empresários, basta examinar os relatórios das federações. No Sul, por exemplo, as mobilizações que nos últimos anos surtiram efeitos razoáveis foram justamente as que visavam alterações na política econômicofinanceira governamental e por isso eram interclassistas. Além disso, os sindicatos, em especial as federações, via de regra, somente assumem esses movimentos setoriais e localizados, quando já estão em andamento. ${ }^{52}$

\footnotetext{
${ }^{51}$ Como é sabido, no Sul os setores da Igreja vinculados ao movimento social no campo, em 1964 aliaram-se a organizações patronais do tipo da Farsul - Federação da Agricultura do Sul e a nível nacional com a CNA Confederação Nacional da Agricultura.

${ }^{52}$ Os trabalhos principais da Fetag/RS centram-se basicamente nas reivindicações econômico-administrativas referentes à produção de soja, fumo, uva, cebola, batatinha, suinocultura etc. A federação assume as mobilizações de trabalhadores rurais somente após iniciados espontaneamente. Todas as mobilizações, no entanto, se referem a problemas imediatos e específicos e envolvem conjuntamente cooperativas e secretarias de Estado em nome de "classe rural". Evidentemente, outros temas entram em pauta, inclusive a questão da "reforma agrária" e a própria repressão policial sobre líderes rurais, mas não têm acesso às estâncias decisórias (Fetag/RS, 1980; 1981). Talvez a melhor maneira de avaliar a
} 
Importa notar que é justamente na tolerância desse tipo de imobilização, no rigoroso cuidado para que não extrapole os limites de problemas imediatos, econômico-administrativos e localizados, que consiste a estratégia básica do Estado. Em outras palavras, a preocupação maior para as autoridades públicas é que esses movimentos não se ampliem quanto à temática e extrapolem o puramente econômico e setorial, questionando diretamente a "racionalidade" político institucional. Isso é facilitado, inclusive, pela característica básica de qualquer movimento político e, em especial, de movimentos políticos camponeses, que começam por questões imediatas e específicas.

Por outro lado - e contraditoriamente - a própria degeneração das condições sócioeconômicas da maior parte do campesinato em constante ameaça de marginalização pura e simples tem levado boa parte de sindicatos rurais a proporem e a assumirem reivindicações progressivamente mais amplas e "políticas". Esse processo resulta numa incipiente bipolarização entre os sindicatos, abrangendo também os setores da Igreja envolvidos com a questão. Em termos de Igreja católica, a manifestação mais nítida desse processo é a "reciclagem" dos antigos setores envolvidos com a questão agrária, que começam a sentir a perda da hegemonia e se sentem "traídos" pelo Estado autoritário no que se refere às consequiências sociais de suas políticas. Como contraponto a essa "reciclagem", no tocante aos setores da Igreja, a manifestação principal é o surgimento da CPT - Comissão de Pastoral da Terra, tendo em vista seu apoio ao sindicalismo "autêntico" e envolvimento com os pequenos camponeses e assalariados rurais (Folha da Manhã, 20 de março de 1981).

É nesse contexto social e político que se inscreve a mediação e representação política no complexo avícola, em especial, e na agroindústria no Brasil em geral. Do ponto de vista do capital, a readaptação dos canais e do exercício do poder e o crescimento econômico assegurado pelo Estado solucionaram tanto o problema da mediação política quanto da expansão econômica e da lucratividade. Por outro lado, a evolução das contradições sociais colocadas por esse processo recoloca também o problema da representação de interesses e canais de participação do ponto de vista daquelas classes excluídas, tanto social quanto politicamente. Embora isso possa ter começado por aqueles setores menos excluídos e dentro da nova "racionalidade" implantada, o encaminhamento dos interesses dos setores realmente excluídos requer novas formas de mediação e representação.

assimetria de poder e acesso a instâncias decisórias é examinar as formas de acesso mais comum dessas associações como os sindicatos - que se dão normalmente através de comissões ou envio de correspondências às autoridades e compará-las com a participação direta nas instâncias decisórias das associações empresariais. 


\section{CONCLUSÕES}

Nos últimos anos, no Brasil, tem-se desenvolvido um debate que tende naturalmente a se ampliar, sobre a natureza dos produtores rurais familiares integrados ao complexo agroindustrial. ${ }^{53}$

As hipóteses fundamentais na caracterização desses grupos tendem a se polarizar em torno de dois paradigmas. Enquanto para uns tratar-se-ia de trabalhadores para o capital, isto é, os produtores familiares estariam diretamente subordinados ao capital e sendo por ele expropriados, para outros estaríamos presenciando a formação de camadas de burgueses e pequeno-burgueses.

Existe, sem dúvida, um amplo espaço nesse debate sobre a propriedade no uso dos conceitos utilizados por essas perspectivas. Porém esse tipo de confrontação, sem ser irrelevante, é limitado em seus resultados e perspectivas. O que nos interessa indicar aqui é que o uso exclusivo de categorias analíticas provenientes do estudo do modo de produção capitalista leva a nos descuidarmos das especificidades das relações sociais realmente existentes no campo, as quais, embora inseridas e subordinadas aos circuitos de acumulação capitalista, mantém rasgos próprios. Quando esses rasgos não são reconhecidos, perde-se a capacidade de entender a especificidade das lutas desses grupos sociais, suas condições de existência e seu universo simbólico, além dos limites que apresentam e representam à acumulação de capital.

No presente trabalho, procuramos mostrar alguns aspectos que caracterizam esses produtores e a sua relação com a acumulação do capital agroindustrial:

1. O duplo sentido da integração, como mecanismo pelo qual a agroindústria assegura seu abastecimento monopsônico e como forma pela qual o produtor familiar garante sua sobrevivência.

Para o produtor integrado, a questão básica não é sua subordinação ao capital industrial, mas a possibilidade e ameaça presente de sua exclusão definitiva das mínimas condições de produção, representada funda mentalmente pela ameaça da perda total da terra que se constitui no principal meio de produção numa agricultura desse tipo. Por outro lado, para os produtores em bases familiares, a integração não se apresenta de imediato em seu aspecto de exploração, posto que esses produtores sempre estiveram subordinados ao capital comercial tradicional, e, por isso, sua integração e subordinação ao moderno capital industrial-financeiro se apresenta de imediato como a possibilidade de desenvolvimento da produção, através do desenvolvimento tecnológico e da melhoria das condições de realização da produção. Em outras palavras, e grosso modo, a espoliação na compra da produção pelo capital industrial-financeiro é mais sistemática e previsível e menos

\footnotetext{
${ }^{53}$ Sem ser unia lista exaustiva, podem-se consultar: N. Nanderley (1979), Graziano da Silva (1979), P. Sandroni (1980), P. Beskoff (1979), B. Sorj (1980), Coradini e Fredericq (1981), J.V. Tavares (1978), G. Müller (1981) e J.L. Lopes (1978).
} 
especulativa que o capital usurário e comercial tradicional, pelo menos em sua manifestação, além de estar mais estreitamente vinculada à coordenação e mediação do Estado.

Existem elementos ideológicos, como por exemplo a própria "insegurança" da produção agropecuária, que, pelo menos na representação, é amenizada pela integração. Tanto que a própria integração é seletiva. Pode-se levantar a hipótese de que o caráter de segurança que a produção de auto-consumo tinha foi desequilibrado pela produção diversificada para o mercado, sendo substituído pela integração, ou seja, pela maior participação num intercâmbio monopsônico.

2. Os limites da integração estão dados por dois fatores: a capacidade de resistência do produtor rural e os limites objetivos que este apresenta a certos níveis de concentração da produção. No primeiro caso, temos a capacidade de resistência - organizada ou não - que o produtor familiar pode opor à integradora, seja se retirando, seja exigindo maiores margens de ingresso, levando a empresa a optar pela integração vertical. No segundo caso, a integração vertical se imporia porque os ganhos de escala que ela permitiria seriam superiores às vantagens do uso da integração de produtores familiares. Contra isso, existiriam, porém, as imobilizações necessárias em terra e capital fixo e as perdas de produtividade pelo uso de trabalho assalariado frente à responsabilidade individual e ao autocontrole da produção familiar.

3. O caráter social específico dos produtores familiares integrados é dado pelo tipo de reivindicação e organização que os caracteriza. Essas reivindicações têm como sustento o preço recebido pelo produto ou a redução do preço dos insumos. A forma mais importante de organização de autodefesa que gera é a cooperativa, pela qual os produtores procuram se transformar, eles mesmos, em parte do complexo agroindustrial. Portanto, se bem que se confrontem também eles com o capital, as características dessa oposição não podem ser assimiladas às dos trabalhadores assalariados.

4. A dinâmica de transformação dos produtores familiares deve ser entendida a partir do problema do controle da terra e das exigências colocadas pela agroindústria. E nesse contexto de luta pela sobrevivência enquanto produtor familiar que se dá um processo de seleção/expulsão. Esse processo não implica necessariamente aburguesamento ou proletarização rural, e sim, a geração de condições de permanência enquanto produtor rural ou sua expulsão enquanto produtor viável. As categorias analíticas do modo de produção capitalista, embora necessárias, são, portanto, insuficientes para se compreenderem as relações sociais no meio rural.

5. A questão da expropriação do sobre-trabalho do produtor familiar não pode ser concebida da mesma forma que a exploração capitalista do trabalho assalariado. Parte do sobre-trabalho é apropriada pela sociedade (Zamosc, 1979). A parte apropriada pela integradora corresponde aos juros do capital avançado e, geralmente, uma outra parte, a capacidade de imposição de preços mais 
baixos que o preço médio do produto vendido no mercado não-integrado.

6. Essas considerações podem ser sintetizadas na fórmula segundo a qual os produtores familiares são transformados pelo processo de integração agroindustrial, e são subordinados e explorados no seu caráter de produtores familiares. Isso determina a especificidade de suas formas de organização, de perspectiva simbólica e de luta. A formação e a dinâmica da integração horizontal depende diretamente da preexistência de determinadas condições históricas no tocante à formação da estrutura agrária e do contexto (econômico, técnico e político) que a empresa integradora tem à disposição para o estabelecimento de suas estratégias.

7. Ao nível da problemática da representação política nas novas condições de integração da produção rural ao complexo agroindustrial, procuramos mostrar que elas levam a uma crescente segmentação do campesinato. De um lado, aqueles que se atrelam ao complexo agroindustrial e, de outro, aqueles que deles ficam marginalizados. Nesse sentido, contestamos a visão que procura enfatizar a unidade do campesinato por este se contrapor ao capital.

8. As reivindicações políticas dos diferentes segmentos de produtores familiares tendem a ser diferenciadas, pois, embora contrapostos ao capital, sua sobrevivência concreta passa por reivindicações e mecanismos de representação diferentes. Por um lado, as camadas integradas canalizam suas reivindicações de ordem econômica, dentro e através de instituições estatais ou associações privadas. Seu horizonte normal de politização se refere à capacidade de se tornarem autônomas das associações representativas em que estão incluídas juntamente com os oligopólios agroindustriais, e criarem suas próprias organizações. As camadas que se marginalizam do processo de integração econômica, por sua vez, realizam reivindicações de ordem mais claramente política, referentes a reformas sociais ou políticas sociais paliativas. Porém, sua capacidade reivindicativa depende, em boa parte, de terem suas exigências assumidas por instituições político-ideológicas mais amplas (partidos, Igreja...), não-originárias, portanto, de seu peso econômico específico e de instituições próprias de representação. 


\section{BIBLIOGRAFIA CITADA}

Araújo, José S.A. de et al. (1976) "Sistema agroindustrial avícola do Estado do Rio Grande do Sul". Porto Alegre, FDRH, mimeog.

Beskow, Paulo R. (1979). "Agricultura e capitalismo no Brasil", mimeog.

Barrios, Daniel Lima de Alvarenga (1979). Economias de escala e processo de produção de ovos na Região Sul de Minas Gerais. Lavras, Escola Superior.

Barrios, Daniel Lima de Alvarenga e Silva, José Teixeira da (1978)."Aspectos técnicos e econômicos da produção comercial de ovos no Sul de Minas". Belo Horizonte, Emater/MG.

BDMG ( Banco de Desenvolvimento de Minas Gerais) (1980). "Programa de Desenvolvimento da Avicultura de Corte". Belo Horizonte, BDMG.

CEPA/MG (1977) "Aspectos econômicos da avicultura de corte em Minas Gerais". Belo Horizonte, CEPA/MG.

Cardoso, Fernando Henrique (1975) "A questão do Estado no Brasil", in Autoritarismo $e$ democratização. Rio de Janeiro, Paz e Terra.

Cebrae/Ceag/SC (1977) "Programa de desenvolvimento industrial de frigoríficos de suínos e aves de Santa Catarina". Florianópolis, Cebrae/Ceag/SC.

Cebrae/Ceag/SC (1978) "Análise do sistema de integração agroindustrial em suínos e aves em Santa Catarina". Florianópolis, Cebrae/Ceag/SC.

Coradini, Odacir Luis e Fredericq, Antoinette. (1982) Agricultura, cooperativas e multinacionais. Rio de Janeiro, Jorge Zahar, 1982.

Fernandes, Evandro de Abreu (1980) "Avicultura mineira: uma exploração em debate". Belo Horizonte, Emater/ MG. (1981) "Projeto: frango de corte e ovos". Belo Horizonte, Emater/MG.

Fernandes, Evandro de Abreu e Ferreira, Marília Martha (1981) "Análise da exploração avícola de Minas Gerais". Belo Horizonte, Emater/ AAMG.

Ferreira, L.A. Alves (1979) "Avicultura de corte na região de Viçosa". Viçosa, Emater/MG.

Forman, Shepard (1979) Camponeses: sua participação no Brasil. Rio de Janeiro, Paz e Terra.

Goodman, David, Sorj, Bernardo e Wilkinson, John (1982) Terra, natureza e capital: uma crítica à economia e à sociologia rural, minteog.

Guimarães, Alberto Passos (1971) A crise agrária. Rio de Janeiro, Paz e Terra.

Graziano da Silva, J. (1980) "A pequena produção e as transformações da agricultura brasileira", in Cadernos do CEAS, n9 69.

Homem de Melo, Fernando (1980) "Agricultura nos anos 80: perspectivas e conflitos entre objetivos da política", in Estudos Econômicos, São Paulo, maio-agosto.

Lopes, Juarez Rubens Brandão (1978) "Empresas e pequenos produtores no desenvolvimento do capitalismo agrário em São Paulo (1940-1970)", in Estudos Cebrap, n. 22.

Mann, Susan A. and Dickinson, James M. (1978) "Obstacles to the development of a capitalist agriculture", in The Journal of Peasant Studies, 5 (4).

Ministério da Agricultura/Suplan (1976) "Projeto de Desenvolvimento da Suinocultura Catarinense". Florianópolis: MA/Suplan/BID/IICA/Acaresc. 
Ministério da Agricultura (1977) "Perspectivas da agricultura brasileira para 1977-78". Brasília.

Moreira, K.J. [s/d] "A pequena produção e a composição agrária de capital", mimeog.

Muller, Geraldo (1981) "Pequenos produtores na industrialização do campo promovida pelo Estado", mimeog.

O'Donnell, Guilhermo (1976) "Sobre o 'corporativismo' e a questão do Estado", in Cadernos do Departamento de Ciência Política, n. 3, Belo Horizonte.

1981 "Anotações para uma teoria do Estado", in Revista de Cultura \& Política, S. Paulo. nov.-janeiro.

Roani, Casimiro et al. (1977) "Sistema agroindustrial de suínos no Rio Grande do Sul”. Porto Alegre, FDRH, mimeog.

Sadia 19781979 Annual report. São Paulo, Sadia.

Sampaio, Plinio (1977) "Capital estrangeiro na agricultura brasileira", mimeog.

Sandroni, Paulo (1980) Questão agrária e campesinato. São Paulo, Polis.

Sorj, Bernardo (1980) Estado e classes sociais na agricultura brasileira. Rio de Janeiro, Zahar.

Tavares dos Santos, José Vicente (1978) Colonos do vinho. São Paulo, Hucitec.

Wanderley, Maria Nazareh (1979) "O camponês: um trabalhador para o capital", mimeog.

Zamosc, Leon (1979) "Notas teóricas sobre la subordinación de la producción mercantil campesina al capital', in Estudios Rurales Latinoamericanos, v. 2, n. 3.

\section{REVISTAS E PERIÓDICOS}

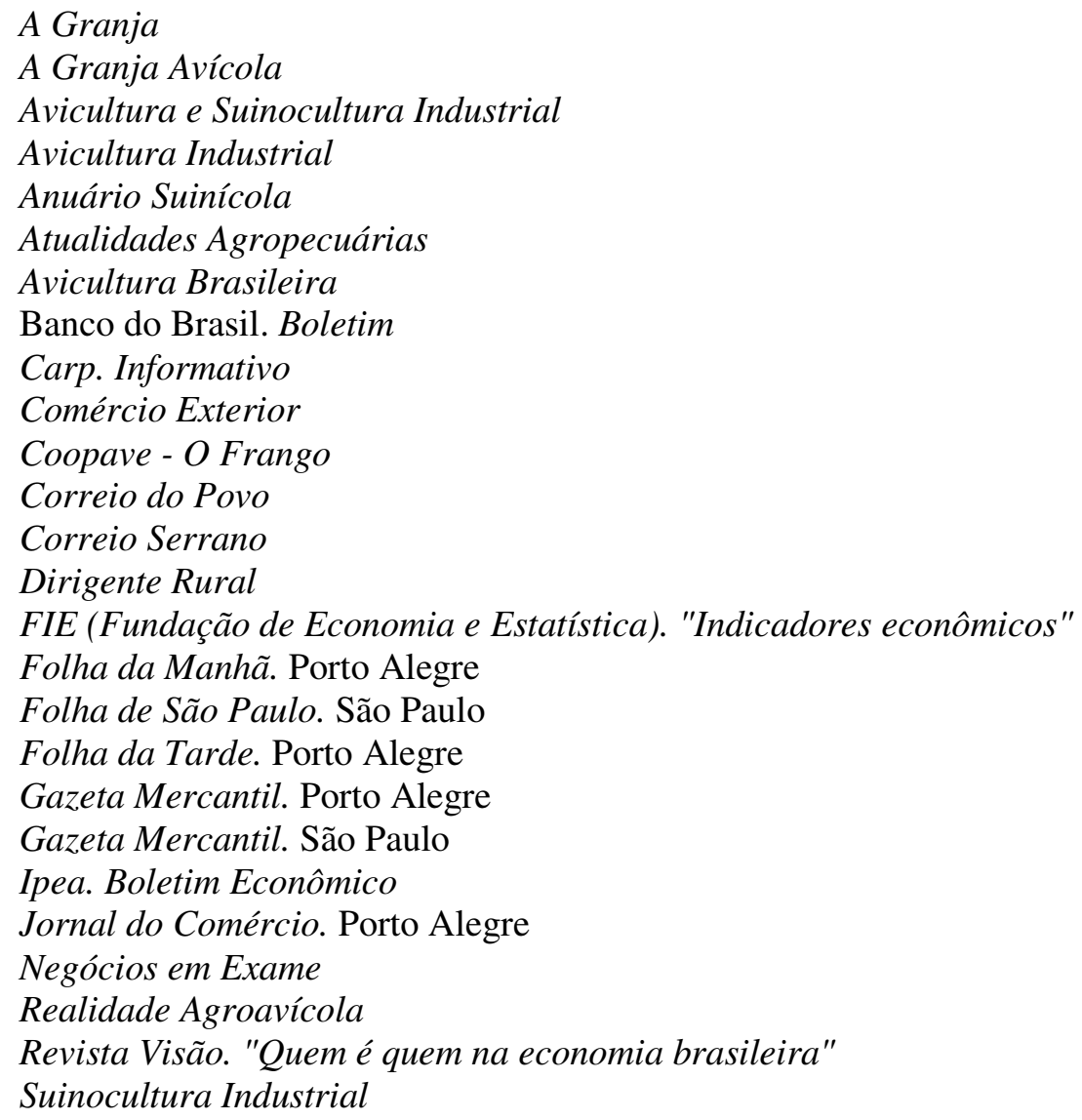




\section{APÊNDICE: \\ CONTRATO DE COMPRA E VENDA EM FORMA DE INTEGRAÇÃO}

Por este instrumento particular de compra e venda em forma de integração, de um lado, AVES S.A., empresa industrial estabelecida nesta cidade de Marau, neste ato representada por seu gerente infra firmado, doravante denominada simplesmente "INTEGRADORA", e de outro lado, TOSE DA SILVA, doravante denominado simplesmente "INTEGRADO", visando a produção de frangos de corte e viabilizar a atividade criatória do INTEGRADO e a atividade industrial da INTEGRADORA, têm justo e contratado as cláusulas e condições seguintes:

1. O INTEGRADO se obriga a criar frangos para os entregar à INTEGRADORA, mediante as seguintes obrigações recíprocas:

a) - A INTEGRADORA obriga-se:

- Fornecer assistência técnica e veterinária para o perfeito desenvolvimento e funcionamento da atividade criatória;

- Fornecer assistência e acompanhamento no projeto de construção ou reforma de galinheiros e instalações;

- Fornecer assistência e acompanhamento nas propostas de financiamentos bancários e creditícios, tanto de investimentos, como de custeio;

- Fornecer pintos de um dia, diretamente na unidade criatória do INTEGRADO, adquiridos de terceiros, dentro das condições do mercado;

- Fornecer na unidade integratória do INTEGRADO o concentrado para pintos e para galetos, à granel, pelo preço posto fábrica, desde que a distância não ultrapasse $30 \mathrm{~km}$, caso em que será combinado uni frete adicional;

- Retirar toda a produção de frangos nos dias previamente estipulados pela INTEGRADORA, nas condições de sua industrializaç3o, podendo autorizar a venda para terceiros, se esta não tiver condições de absorver a produção do INTEGRADO;

- Pagar no mínimo os preços fixados pela Associação dos Matadouros do Rio Grande do Sul-Amars, descontado o Funrural do vendedor.

b) - O INTEGRADO obriga-se:

- Acatar e cumprir as instruções emanadas da assistência técnica na sua totalidade, ficando por sua responsabilidade os problemas que surgem pela não observância das instruções técnicas, especialmente manter as instalações em perfeito estado sanitário;

- Adquirir somente da INTEGRADORA ou de quem por esta for indicada, pintos e concentrados protéicos, estes por preços e condições de mercado;

- Entregar as aves engaioladas e postas sobre o caminhão em prazo estipulado pela 
INTEGRADORA, de acordo com o fluxo de abate e as condições cio mercado;

- Vender a totalidade dos frangos para a INTEGRADORA salvo autorizaç5o por escrito desta, para efetuar a venda a terceiros;

- Cumprir rigorosamente os prazos e condições estipulados nos contratos assinados de financiamentos bancários;

- Permitir o livre acesso dos representantes da INTEGRADORA às dependências dos aviários, objetivando orientação e fiscalização.

2. O peso das aves, para cálculo de preço, será de acordo com o recebido e abatido na indústria, descontadas as carcaças condenadas pela Inspeção Federal, obedecendo as normas ltigiénico-sanitárias vigentes, comprometendo-se o INTEGRADO a evitar que os frangos a serem entregues ingiram qualquer alimento durante as doze horas que antecedem a entrega.

3. Correrão por conta do INTEGRADO o seguro dos lotes de frangos, manutenção, guarda e prejuízos que advierem por mortalidade de qualquer tipo.

4. A parte que não cumprir o contrato aqui, no todo ou em parte, especialmente nos prazos ajustados, pagará uma multa convencional equivalente a 150 (cento e cinqüenta) ORTNs, além das perdas e danos, custas judiciais e honorários advocatícios. 5. O presente contrato terá vigência pelo prazo de 60 (sessenta) meses, a contar da data da assinatura deste, sendo que a parte que desejar rescindir antes deste prazo dará à outra uni pré-aviso por escrito de 6 (seis) meses de antecedência.

6. A INTEGRADORA fica com direito de retenção de pagamentos para assegurar o pagamento por parte do INTEGRADO para terceiros fornecedores de pintos em negócios realizados através daquela.

7. As partes elegem o foro da comarca de Marau, RS, com expressa renúncia de qualquer outro, para solução de qualquer dúvida ou litígio decorrente deste contrato. E, por assim estarem justos e contratados, firmam o presente em duas vias de igual teor na presença das testemunhas abaixo. 